Portland State University

PDXScholar

Spring 4-26-2013

\title{
From Company Town to Company Town: Holden and Holden Village, Washington, 1937-1980 \& Today
}

Mattias Olshausen

Portland State University

Follow this and additional works at: https://pdxscholar.library.pdx.edu/open_access_etds

Part of the History of Religion Commons, Other History Commons, and the Public History Commons Let us know how access to this document benefits you.

\section{Recommended Citation}

Olshausen, Mattias, "From Company Town to Company Town: Holden and Holden Village, Washington, 1937-1980 \& Today" (2013). Dissertations and Theses. Paper 717.

https://doi.org/10.15760/etd.717

This Thesis is brought to you for free and open access. It has been accepted for inclusion in Dissertations and Theses by an authorized administrator of PDXScholar. Please contact us if we can make this document more accessible: pdxscholar@pdx.edu. 
From Company Town to Company Town:

Holden and Holden Village, Washington, 1937-1980 \& Today

by

Mattias Olshausen

A thesis submitted in partial fulfillment of the requirements for the degree of

\author{
Master of Arts \\ in \\ History
}

Thesis Committee:
Katrine Barber, Chair
Carl Abbott
Tim Garrison
Chia Yin Hsu

Portland State University

2013 


\begin{abstract}
In 1937, Howe Sound Company built the town of Holden, Washington, to support its copper-mining operation at Copper Peak, located in the North Cascade Mountains, approximately 10 miles west of Lake Chelan. The operation produced concentrate from 1937 to 1957 , during which time the town was home to a lively community featuring many families, a variety of organized recreational activities, and a public school. It was a company town, in which most property, business, organized activity, and public utilities and services were either directly or indirectly controlled by Howe Sound. After the operation shut down in 1957, the town was abandoned.

Three years later, the property was donated to the Lutheran Bible Institute of Issaquah, Washington. It subsequently became Holden Village, an independent, nonprofit Lutheran retreat center. Though different in purpose and character from the community that preceded it, life in Holden Village during its formative years (the 1960s and, to a lesser extent, the 1970s), and in the 2010s, was and is similar in a number of ways to life in the mining town. This thesis argues that Holden Village, too, might be considered a company town within a loose definition of the term. The many parallels between the two communities support this argument, and point to the role of the remote setting and the environment in shaping the lives of the town's residents.
\end{abstract}




\section{ACKNOWLEDGEMENTS}

I would like to thank the following people for their assistance with this project: Holden experts and former residents Larry Howard, Bill Phillips, Linda Powell Jensen, Werner Janssen, Dr. Christine Plimpton, Paul Hinderlie, Tom Ahlstrom, Bob Hewitt, Pat Schonders, Gene Starcher, Don Wilson, and Brent Diamond; my advisor Dr. Katrine Barber, and other members of my thesis committee, Dr. Carl Abbott, Dr. Tim Garrison, and Dr. Chia Yin Hsu; and the staffs of the Chelan Museum, the University of Washington Allen Library, the Drake University Cowles Library, the Iowa State University Parks Library, the Wenatchee Public Library, the Issaquah Public Library and the Urbandale Public Library.

Judy Clark, Marilyn Larson, Leslie Succo, and Larry and Ann Thomas all gave me a place to stay while I was doing research outside of Holden. I would like to thank all of them for their hospitality, as well as my parents, with whom I stayed while writing this.

Lastly, I would like to thank all the members of the 2011-12 Holden Village Community, who made living there for fourteen months one of the best experiences of my life. Directors Chuck and Stephanie Carpenter and the rest of the village staffing committee made that time possible by entrusting me with a long-term staff position. Since leaving the village, I have received the encouragement of numberous Holden friends but none has been more supportive than John Colman- a great fire chief, fishing buddy, and traveling companion. 
Table of Contents

List of Figures........................................................................................iv

Introduction: Holden as Company Town; Historiographical Background....................1

Chapter One: Holden, the Mining Town................................................................... 15

Chapter Two: Early History and Development of Holden Village.............................69

Chapter Three: Analysis of Key Parallels (And Some Differences) Between the Two

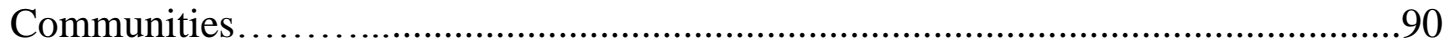

Conclusion: Holden's Significance, Identity, and Future....................................115

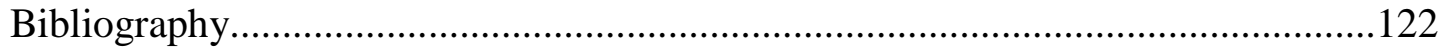

Appendix A: The 1940 U.S. Census: Author's Analysis........................................126

Appendix B: The 1940 U.S. Census: Bill Phillips' Analysis...................................128 


\section{LIST OF FIGURES}

Page 12: Map of Holden's location in the Lake Chelan area (not to scale). From the Holden Village website.

Page 13: Trails map showing general Holden vicinity. From the Holden Village website.

Page 14: Holden from Honeymoon Heights (Kirsten Olshausen, 2011); the Hotel building from Main Street with Martin Ridge in the background (author, 2012).

Page 67: View of mill structure and buildings at level of mine portal looking southwest from Winston Camp with Buckskin Mountain in background. Courtesy of Gene Starcher.

Page 68: Visitor's map of Holden Village. From the Holden Village website. 


\section{INTRODUCTION: HOLDEN AS COMPANY TOWN; HISTORIOGRAPHICAL BACKGROUND}

Company towns are communities characterized by the control of one commercial enterprise, often a mining, lumber, or railroad company, over all or virtually all employment, housing, public utilities and services, business, and organized social activity in that town. In the West, and throughout the United States in general, company towns were widespread throughout the late nineteenth and early twentieth centuries. Since that era, a number of factors have led to their decline, and now only a few remain in operation in any part of the country. Especially in the West, their existence was often justified by the need to extract resources in locations sufficiently remote from larger settlements so as to make any kind of commute to and from those settlements impractical. As the West grew more settled, however, distances between towns and cities shrank; the development of modern highway and freeway systems played a part in reducing the isolation of many company towns, as did a rise in the availability of inexpensive automobiles to workingclass families, thereby eliminating much of the need to operate company towns as such. ${ }^{1}$ Company towns typically met one of two fates. When the commercial enterprise that created them terminated production at the local mine or mill, they survived as independent communities, or they became ghost towns.

Holden, Washington, ultimately met neither fate. The town is located in the North Cascades at an elevation of 3,200 feet, approximately 10 miles west of Lake Chelan by Forest Service Road 8301. The surrounding peaks range between 7,000 and 9,500 feet. The nearest incorporated town is Chelan, at the southern end of the lake, more than 50 miles away. Holden's only neighbors are the unincorporated communities

\footnotetext{
${ }^{1}$ Margaret Crawford, “The 'New’ Company Town,” $\underline{\text { Perspecta, }} 30$ (1999): 48-57, 55. 
of Lucerne and Stehekin, the former being nothing more than a cluster of cabins and a ranger station on the lakeshore, and the latter being a somewhat larger resort community at the northern end of the lake. Holden is not connected to any highway system, and can only be reached by taking the lake ferry or a float plane to Lucerne and then driving up the road, by helicopter, or by foot trail. The townsite stands on land leased from the Forest Service, and is roughly a mile away from the boundary of Glacier Peak National Wilderness.

From 1937 to 1957, Holden was the site of the largest copper-mining operation in the state of Washington. It was owned and operated by Howe Sound Company, which had its headquarters in New York. The average yearly population was between 600 and 700, and when the mine closed, many of the residents were compelled to abandon homes of between 10 and 20 years. After standing vacant for three years, the main townsite was donated to the Lutheran Bible Institute of Issaquah, Washington. It then became an independent, non-profit, Christian retreat center, called Holden Village. It survives today in this form.

A present-day visitor to Holden Village sees much of what its former residents, the miners, saw. The townsite consists of six two-story, dormitory buildings (one now converted to other uses), fourteen chalet-style houses, a recreation hall, the Hotel building, which holds the dining hall and village bookstore; a former hospital building, now a living unit; and a school building. Except for one of the chalets, all are original structures, built between 1937 and 1938. The Forest Service road, which divides the rec hall, the school, and two of the dormitory buildings on the south from the rest of the townsite on the north, forms the town's only street ("Main Street"). Martin Ridge looms 
above the village on the north. Across the creek, on the south side of the valley, Buckskin Mountain and Copper Peak dominate the view. Three enormous mounds of orange mine tailings border the creek, and three smaller heaps are visible on Copper Peak's lower slopes. To the west of the larger tailings piles stands the rusting skeleton of the ore milling structure, which is flanked by slopes covered in additional waste rock material. On the level of the mine portal, just uphill from the mill, foundations mark where shops and office buildings once stood. Beyond the sealed portal there are 58 miles of tunnels, now mostly underwater. ${ }^{2}$ (Holden Village structures on this side of the creek include the current maintenance garage and an abandoned museum building). Only traces remain of the larger physical community that existed during the mining years, which included two neighborhoods populated mainly by families and young couples, Winston Camp and Honeymoon Heights. Winston Camp consisted of 101 homes; it stood a few hundred yards to the west of the townsite. Honeymoon Heights consisted of 15-20 homes; it stood on the lower slopes of Copper Peak, not far from the mine portal. In the case of both neighborhoods, only foundations remain today.

On the surface, Holden Village bears little resemblance to the community that preceded it, except in the fact that it occupies the same site. It is a non-profit hospitality organization, rather than a commercial enterprise. Its resident staff consists largely of students, recent college graduates, young families, and retirees, many of whom work and live in the village as unpaid volunteers. Most guests and staff members only stay for brief periods; two years is considered a long stay, although some directors, managers, and village pastors have stayed for five or more years.

\footnotetext{
${ }^{2}$ Brent Diamond, email correspondence with author, 22 December 2012.
} 
Nevertheless, Holden Village, too, might be considered a company town. The evidence for this lies in the many parallels between Holden Village and its predecessor community. First and foremost among these parallels is (1) the fact that employment and residency were and are inextricably linked in both communities. While many of Holden Village's workers are unpaid, those who live there year-round (and, as of 2012, an increasing number of shorter-term residents) receive stipends and health benefits, and can therefore be considered employees. (Moreover, volunteer staff members receive payment in the form of free room and board). In the mining community, any time an employee was dismissed, for any reason, he had no choice but to leave the community. In the village community, while those who are dismissed are usually permitted to return after a time, they, too, must leave. Another important parallel is (2) the rough segregation of the community by housing situation into zones that are reflective of status in the community's unifying enterprise and, generally, length of residency. This segregation was more evident during the mining years, due partly to the existence of Winston Camp and Honeymoon Heights, but exists today at Holden Village in the division between long-term staff members and managers, who live in the chalets, and short-term volunteer workers, who live principally in two dormitories. Further parallels include (3) limited self-government characterized by the leadership of a select group of managers or directors who report to a board or other superiors on the "outside"; (4) limited selfreliance with regard to public utilities and services (with the notable exception of electrical power in the case of the mining community); and (5) the unifying enterprise's support of and involvement in a variety of communal activities and programs, including sports, education, and religion. (In the case of Holden Village, religion is a core element 
of its unifying enterprise). Similarities less critical to the argument that Holden Village is a company town but relevant to an accurate characterization of Holden include (6) the vulnerability of both communities to the dangers of the surrounding environment, especially the threat of forest fire, (7) a lack of strong racial diversity, and (8) strong feelings of attachment to the physical community on the part of the residents, often experienced most strongly after leaving or moving away.

At least one conclusion, largely self-evident, may be drawn from these parallels: setting plays a major role in determining the character and composition of any community, and especially one as small and isolated as Holden. It is the remote setting that is most responsible for the similarities between Holden and Holden Village. The location created a range of challenges to both operations, and it played an important role in shaping both communities. This fact need not work against the argument that Holden Village is a company town. Especially in the West, remoteness was a key characteristic of most company towns.

It is partly ambiguity in the modern scholarly definition of what constitutes a company town that leaves room for Holden Village to be interpreted as one. There is no exact definition. In their introduction to Company Towns in the Americas, Oliver Dinius and Angela Vergara identify the town's dependence on a sole industry and that industry's ownership of all or nearly all property as prime characteristics, adding geographical isolation, residential segregation, and company control over public services, education, and recreation as other key factors. In his 1966 book, The Company Town in the American West, James Allen also included the presence of a company store as an important factor. However, as Dinius and Vergara point out, "company towns often met 
several of these criteria, but only a few model towns met all of them." There were numerous fundamental differences between heavily planned communities near major urban areas, such as Pullman, Illinois, and rough logging camps located deep in the forests of the Pacific Northwest, among them the projected longevity of the community and the gender ratio of its population. ${ }^{3}$ Holden during the mining years lay somewhere between these two extremes.

Other modern scholars, such as Hardy Green, author of The Company Town: The Industrial Edens and Satanic Mills that Shaped the American Economy, explore whether some of today's major corporate campuses might be considered company towns, such as Federal Express' huge facility in Collierville, Tennessee, or Google's headquarters in Mountain View, California. Among other amenities, the latter features free meals, exercise facilities, and places for employees to sleep, which effectively encourage them to live at their place of work and blur the lines between their private and professional lives. These facilities are more like company towns than Holden Village insofar that they are owned and operated by for-profit enterprises. However, they would still be nontraditional company towns, and if accepted as such, they would support an expansion of our understanding of what constitutes a company town - potentially opening the door for Holden Village (where the division between work and play is also somewhat blurry) and similar communities to be viewed in the same light. To be sure, Holden Village's status as a non-profit organization would mark it as a highly unusual company town, but that status alone should not exclude it, as the exact nature of the unifying enterprise has not been among the foremost criteria in scholarly definitions of the company town. (Green

\footnotetext{
${ }^{3}$ Oliver J. Dinius, and Angela Vergara, eds., Company Towns in the Americas (Atlanta: University of Georgia Press, 2011), 6-7.
} 
also speculates whether tourism might become the central industry in a new generation of company towns. Holden is not a tourist destination, but many of the services its resident workers provide are not so different from what one would pay for at a commercial resort, especially one in a remote location). ${ }^{4}$

The purpose of this thesis is to argue that Holden Village could be viewed as a company town by further exploring the parallels listed above, not to provide a general history of the two communities. Such a history would properly include many elements that lie outside the scope of this writer's experience, such as the mining methods that helped establish Holden as a successful operation. Readers interested in this aspect of Holden's history might look for articles and theses published by some of Howe Sound's leading men, such as Holden General Manager John J. Curzon, who figures prominently in this thesis for other reasons. Additionally, this thesis will not delve deeply into the theological subjects covered by the generations of visiting summer lecturers who have come to Holden Village since 1961. Readers interested in these subjects may find many of the lectures in the Holden Village Audio Archive, which is gradually becoming available on the Holden Village website, and is currently accessible in the Holden library.

This thesis expands on the existing literature by comparing Holden and Holden Village. Although no one has yet attempted to write about both communities in detail, a number of general histories already exist. Dr. Nigel Adams' 1976 PhD dissertation, The Holden Mine: From Discovery to Production, describes the discovery of the copper ore body by J.H. Holden, his attempts to develop the claim, and Howe Sound's early works at the site. An abridged version of this dissertation was published as a book in 1981.

\footnotetext{
${ }^{4}$ Hardy Green, The Company Town: The Industrial Edens and Satanic Mills that shaped the American Economy (New York: Basic Books, 2010), 191, 202.
} 
Adams' work highlights the importance the Holden mine had for Chelan, which had sunk to an economic low in the 1930s and benefitted from the business Howe Sound brought to town. Having spent part of his childhood at Holden, Adams probably would have produced the authoritative history of Holden during the mining years, but he died before he could complete such a volume. However, there is a Washington State University master's thesis that focuses on one of Holden's "neighborhoods," An Ethnoarchaeological Study of Honeymoon Heights, written by Dr. Christine Plimpton, who also spent part of her childhood at Holden.

The only widely available secondary resource on the mining years is Linda Carlson's Company Towns of the Pacific Northwest. Though it is a survey of conditions in many company towns throughout Washington, Oregon, and Idaho, it makes extensive reference to Holden. Carlson does an excellent job of pointing out aspects of community life that were common to Holden and many other company towns. James Allen's book was among the resources Carlson used. It makes brief reference to Holden, but only to comment on its unusual fate.

Literature on Holden Village is limited to what the retreat center itself has produced. The semi-official history is Charles Lutz's Surprising Gift: The Story of Holden Village, Church Renewal Center, published in 1987. There is a copy of this book in every village guest room. It devotes one chapter to a summary of the mining years, but its main purpose is to chronicle the first 25 years of the retreat center's history. It is a good source of both general and specific information, and anyone interested in studying Holden Village history should use it as a starting point. In 2012, as part of the celebrations marking its fiftieth year as a retreat center, Holden Village published a 
collection of personal recollections written primarily by former village directors, managers, board members, and pastors, titled Holden Village: 50 Years of Memories, and edited by board member Lola Deane. The Holden Village website also includes pages on village history, and on the history of the mining community.

This writer found only one reference to Holden in general histories of the Lutheran church in the United States, in Maria Erling and Mark Granquist's The Augustana Story: Shaping Lutheran Identity in North America, which sheds light on the character of Wilton Bergstrand, one of Holden Village's early leaders. This and other church histories provided insight into the interesting changes that were taking place within the various Lutheran church bodies during the 1960s, some of which may have influenced Holden Village's direction in its formative years.

Holden's lack of a definitive history is somewhat made up for by its rich oral history collection, and by the materials available to guests and staff in its Portal Museum. The former resource includes recorded interviews of both Holden and Holden Village residents. It is interesting to note that the recollections of former miners and their families contained within these interviews are almost universally positive, which challenges the prevailing negative image of the company town model in contemporary culture. (Crandall Shifflet makes a similar observation in his 1991 book, Coal Towns: Life, Work, and Culture in Company Towns of Southern Appalachia, 1880-1960). ${ }^{5}$ The Portal Museum includes memoirs, letters, staff photo albums, and newspaper clippings. Both the Chelan Valley Mirror and the Wenatchee World paid close attention to events at Holden. The Mirror even featured a regular column on Holden for a few years.

\footnotetext{
${ }^{5}$ Crandall A. Shifflet, Coal Towns: Life, Work, and Culture in Company Towns of Southern Appalachia, 1880-1960 (Knoxville: The University of Tennessee Press, 1991), 145.
} 
Additionally, Holden had its own weekly newspaper, The Holden Miner, founded in 1948 by miner Frank Brogan. After Brogan left town in 1950, the paper was written, edited, and published by Howe Sound timekeeper Cortland Bell. ${ }^{6}$ In the late 1980s, a former resident resurrected the paper as a newsletter for and by survivors of the mining community. It regularly includes many interesting and entertaining stories. As of 2012, although almost all the former employees and their spouses have died, many of their children are alive and well, among whom Bill Phillips and Linda Powell Jensen are most active in preserving Holden's history and sharing their stories with today's residents.

Among the primary resources, none is as extensive as the Howe Sound Company files from the Holden operation, which are preserved at the University of Washington in the Allen Library's Special Collections wing. They were discovered at Holden in the 1960s and saved through the efforts of Portal Museum curator Dr. Rudy Edmund, Holden Village Business Manager Werner Janssen, and Dr. Nigel Adams. They include correspondence between General Manager J.J. Curzon and his superiors in New York, internal memos, insurance information, minutes of negotiations between striking union members and company officers, fire reports, and much more. It is clear from the content of these files that Curzon was not solely interested in the success and productivity of the mine itself, but also took a keen interest in the well-being of his workers, their families, and the community as a whole.

There are several living individuals who may be considered Holden history experts, including Bill Phillips, Linda Powell Jensen, Dr. Christine Plimpton, Werner Janssen, former director Paul Hinderlie, and current Portal Museum curator Larry

\footnotetext{
${ }^{6}$ Linda Carlson, Company Towns of the Pacific Northwest (Seattle: University of Washington Press, 2003), 137; Linda Powell Jensen, email correspondence with author, 21 December 2012.
} 
Howard. All have been of great assistance to this writer, who has generally deferred to their recollections of what life was like at Holden when they lived there. The writing of a definitive history of Holden is properly left to one of them.

While this thesis is not intended as a general history, one of its purposes is to provide an overview of Holden's history during the mining years that may be useful as a guide to other researchers, and as an illustration of life in a conventional company town. This overview forms the content of the first chapter. The second chapter consists of an overview of the history of Holden Village up to 1980, by which time the community had, in a number of fundamental ways, become what it is today. Much of this history has already been chronicled in greater depth in Lutz's book; therefore, it is relatively brief overview, though it does include some minor details that have not appeared in previous village histories. The third chapter describes life in the village today and analyzes the most important parallels (and differences) between Holden and Holden Village in greater depth. This chapter summarizes the argument that Holden Village is a company town. The conclusion touches on some less tangible similarities between the two communities, asks and attempts to answer questions regarding Holden's identity and future, and includes suggestions for further research. 


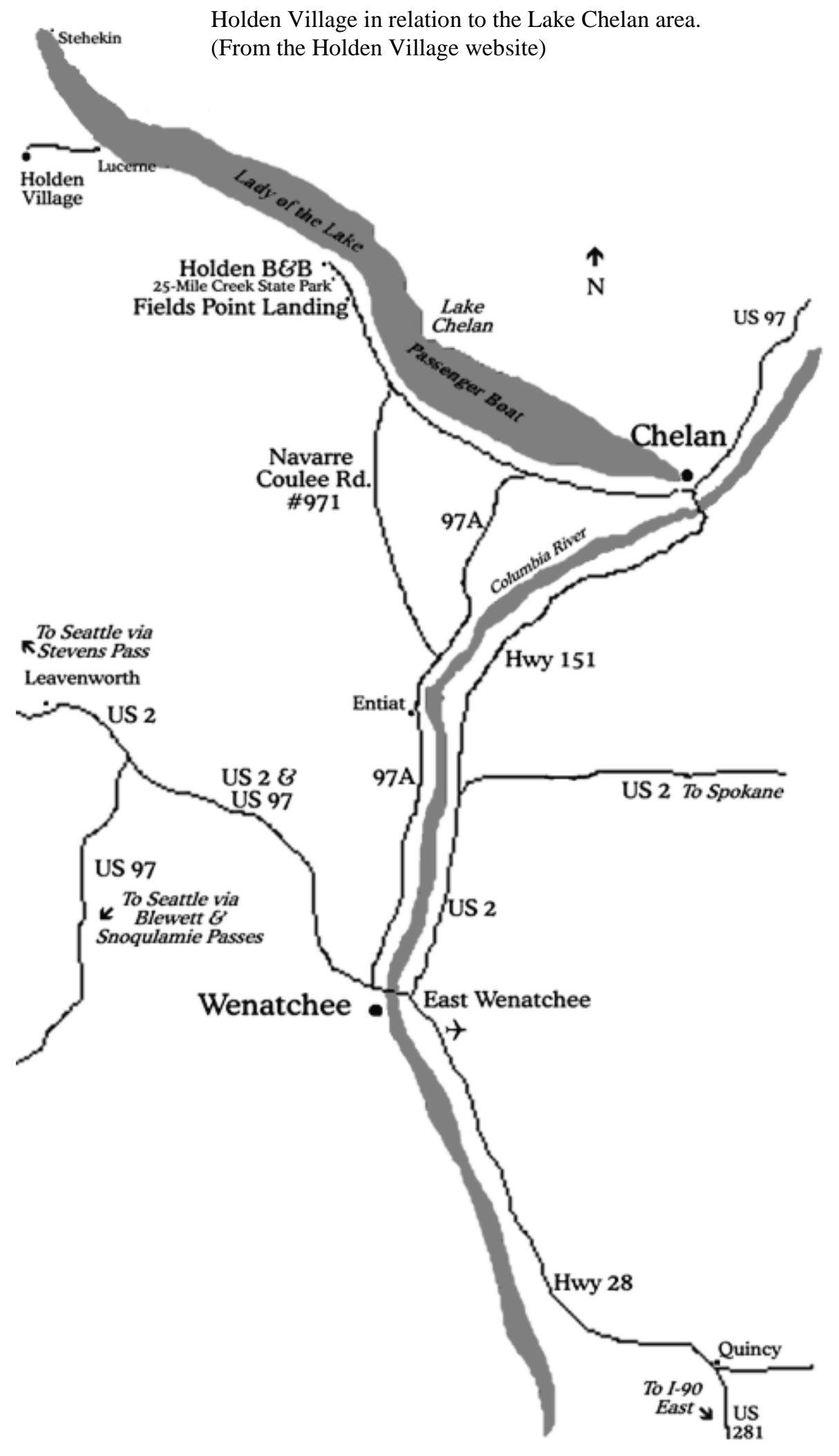




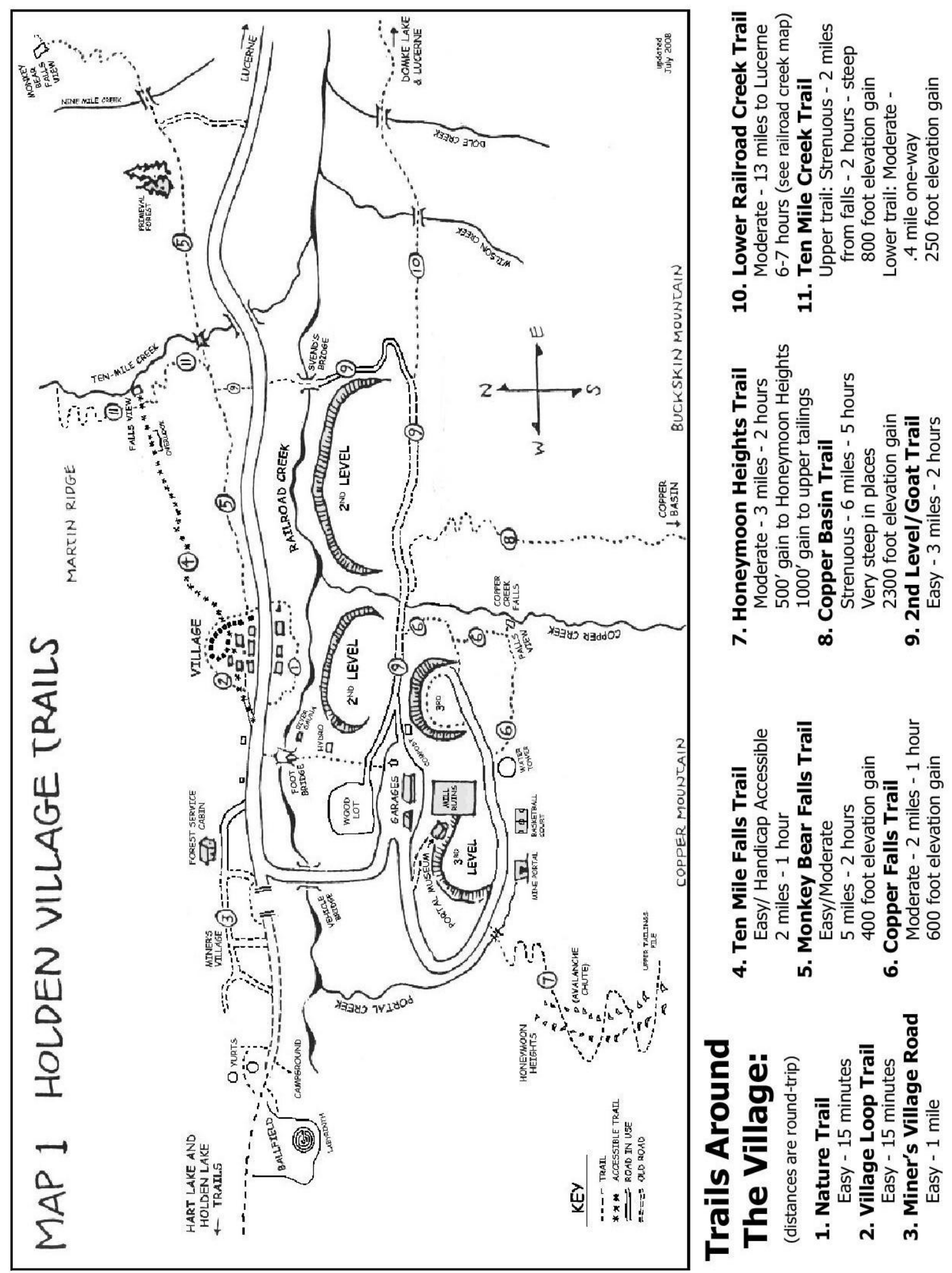

Holden Village guest map showing position of townsite, tailings piles (the " 2 nd level"), the remains of the mill, and the abandoned communities of Honeymoon Heights and Winston Camp (the "miner's village"). (From the Holden Village website) 


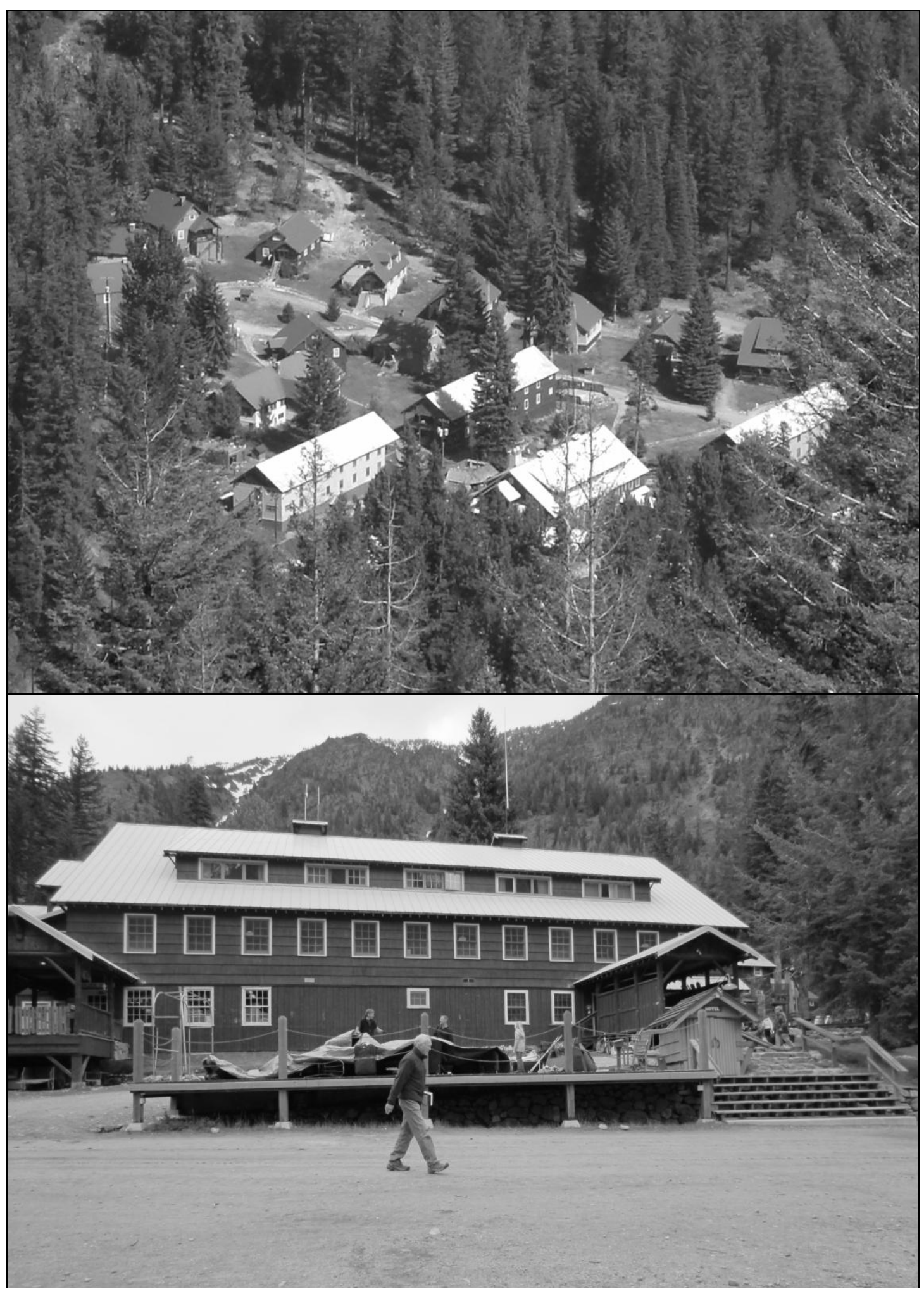

Top: Holden Village from Honeymoon Heights, 2011 (Kirsten Olshausen)

Bottom: The Hotel building from Main Street with Martin Ridge in the background, 2012 (author) 


\section{CHAPTER ONE: HOLDEN, THE MINING TOWN}

Within the conventional definition of a company town, Holden met several common criteria. First and foremost, Howe Sound was the sole industry. The only employed individuals who did not work for the company were the postmaster and a few store clerks. The townsite buildings were built to a standardized design, and where the employees lived was at least partly reflective of their status within the company. The company provided or supported various kinds of communal recreational activity. It supported a high-quality public school. It also provided a number of public utilities and services, including garbage collection, a sewage system, limited medical care, limited fire protection, and limited law enforcement. The management, headed for most of the operation's history by General Manager J.J. Curzon, influenced many aspects of everyday life outside the work environment, though sometimes in ways not widely visible to the entire community.

On the other hand, Holden did not meet other criteria. Howe Sound did not own the land that the townsite or Winston Camp was built on - the Forest Service did. It did not own the homes in Winston Camp, either, though they were tied to the operation, because their residents could not remain in them after the mine shut down. The main parcel of land the company owned consisted of 225 acres of claims on the south side of Railroad Creek, including the Honeymoon Heights location. Although there was a company commissary at one point, it did not play a central role in the life of the community, at least not in the sense that the employees were more or less obligated to shop there and enmeshed in constant debt to it, as was the case in some of the more unpleasant company towns in the West, such as Colorado Fuel \& Iron's notorious coal 
towns of the early twentieth century. Instead, Howe Sound permitted a couple of private businesses to sell groceries and other necessities. What the residents could not obtain from these businesses, they bought on trips downlake, or from catalogs.

Holden was not unique with regard to its spectacular, isolated setting. Other company towns in the Pacific Northwest were located in verdant forested areas and mountain valleys, such as Seattle City Light's Skagit Valley dam towns of Newhalem and Diablo. These two towns, located some 40 miles to the north of Railroad Creek Valley, were nearly as isolated as Holden. However, whereas they were linked to the outside world by rail, and eventually by the North Cascades Highway, Holden's isolation remained at a constant level throughout its 20 years of operation.

\section{Early History}

The history of the Holden site dates back to the nineteenth century. Some Holden Village residents have assumed that Railroad Creek Valley was named for Howe Sound's abandoned early efforts to build a railway between Holden and Lucerne for the transportation of concentrate. In fact, the name derived from the Great Northern Railway's 1880s survey of the valley as a possible route through the Cascades. ${ }^{7}$ The mining history of the valley began on July 24, 1896, with prospector James H. Holden's discovery of the copper ore outcropping on the north side of Copper Peak. Holden spent the rest of his life trying to develop and promote the claim. Although he achieved a measure of financial success by leasing the property, becoming a prominent Chelan citizen in the process, he was ultimately unsuccessful in his attempts to convince a major company to buy the property. Exploratory mining took place during Holden's lifetime

\footnotetext{
${ }^{7}$ Robert Hitchman, Place Names of Washington (Washington State Historical Society, 1985), 246.
} 
(initiating the buildup of the three tailings piles seen above Honeymoon Heights), but he and his men neither concentrated nor smelted any ore, partly because Holden could not finance the technology necessary to effectively mill the low-grade copper.

Holden died in 1918. In 1922, his shares in the local company controlling the site were sold at auction to Chelan businessman Crooker Perry, to whom Holden had been in debt at the time of his death. In 1930, Perry sold the company and the site to Howe Sound Company, which had been leasing the mine since 1928. Falling copper prices halted most work at the site in 1931, and also shut down a number of existing company copper-mining towns, including several in the Southwest. Work resumed in 1937. Howe Sound and its contractors completed building the transportation system (including the road to Lucerne, the docks in Lucerne and Chelan, and the tug and barge), the power system, the ore concentration mill, and the townsite in 1937-38. The first shipment of concentrate arrived in Chelan on April 9, $1938 .^{8}$

\section{The Workers}

Holden's workers came from throughout the country. The 1940 U.S. Census reveals that roughly a third of them were native Washingtonians, and many had been living elsewhere in Chelan County in 1935. At the beginning of the operation, some men came to Holden directly from working on the Coulee Dam project. A 1943 government

\footnotetext{
${ }^{8}$ Nigel B. Adams, The Holden Mine: Discovery to Production, 1896-1938 (Wenatchee: World Publishing Company, 1981), 3-69; Thomas R. Navin, Copper Mining \& Management (Tucson: The University of Arizona Press, 1978), 137.
} 
report stated that the company hired most regular employees through the U.S.

Employment Service. Incoming workers reported to the company office in Chelan. ${ }^{9}$

The men came to Holden to perform hard, often dangerous work for Howe Sound. From 1939 to 1945, the men worked 13 out of 14 days. After the demand for copper fell at the conclusion of World War II, they worked six days a week, and eventually five starting at some point in the late 1940s. This is evidenced by a letter J.J. Curzon wrote to a would-be visitor, in which he stated that both the mine and the mill were closed on Saturdays and Sundays. The operation returned to a six-day schedule in the early 1950s. These changes were in part the result of fluctuations in the price of copper, which obviously affected how much the company could afford to pay its workers.

Except on weekends, during strikes, and during a period of nine months in 194647 when the concentrating mill was shut down to allow time for further development of the mine shaft, the operation produced and processed ore continuously. ${ }^{10}$ Every work day was divided into three eight-hour shifts, each of which included a paid lunch break. Except for the foremen, all or nearly all of the underground workers rotated shifts every two weeks; at least some shop workers worked fixed day shifts. Underground work included "mucking" (gathering chunks of ore knocked loose by other miners), drilling holes for the dynamite-layers, setting support timbers (though in few places, because the hard rock generally did not require timbering), operating the lift that brought men up and down the central shaft, operating the ore transportation train that ran between the mine

\footnotetext{
${ }^{9}$ Henry McKay Mitchel, "Report of Chelan Division, Howe Sound Company, Holden, Chelan County, Washington (for the Department of the Interior, Bureau of Mines, Mineral Production Security Division)," July 1943, Special Collections, Allen Library, University of Washington, Seattle.

${ }^{10}$ J.J. Curzon to H.H. Sharp, 13 and 20 August, 1945, Special Collections, Allen Library, University of Washington, Seattle; J.J. Curzon to E.O. Barthol, 3 August, 1949; "280 Miners Idled by Holden Strike," Wenatchee World, 28 October 1954; "Holden Mill Closing; Mill to Absorb Extra Workers," Chelan Valley Mirror, 7 November 1946.
} 
and the mill, and other jobs. The shop and surface workers included blacksmiths, carpenters, electricians, machinists, mechanics, truck drivers, and warehousemen. Office workers included chemists, geologists, engineers, accountants, timekeepers, and stenographers. $^{11}$

The mine attracted graduates from geology and engineering programs throughout the West. Many of their applications survive in the company files. With possible rare exceptions, J.J. Curzon never took on any of these young men unless they were willing to work underground first, as Howe Sound maintained a policy of filling engineering positions from within the company. In a typical response to one application, Curzon wrote: "There are no openings on our engineering or geological staff at this time. When openings do occur they are always filled by promoting someone from within our own organization. The only thing we can offer you is a job in the mine starting in at the bottom, taking your chances on a promotion later if an opening should occur."12 Some of the applicants were either unwilling or unable to accept this offer, but others used it as the basis for long and successful careers. Engineers John Bley and Wellington "Wimpy" Phillips, both of whom eventually became mine superintendent, started in the mine. (In Bley's case, he kept his education a secret from all but the managers during his stint underground). According to a former employee who attended a miners' reunion at Holden Village in 1992, there were as many as 17 college graduates working underground in 1938. ${ }^{13}$ The obvious reason for this policy, and the one that Curzon gave

\footnotetext{
${ }^{11}$ Linda Carlson, "Miners Reunion: Married to the Mine, Women during the Mining Days," Holden Village Audio Archive; Jack \& Betty Frye, "Life in Holden During the Mining Days," 1982, Audio Archive; Linda Powell Jensen, email correspondence with author, 21 December 2012.

12 J.J. Curzon to Jerome H. Sorkin, 9 December 1947.

${ }^{13}$ John \& Ruth Bley, "Holden as a Mining Town: The Way It Was," 1981, Audio Archive; Bill Phillips, guided tour, 11 September 2010; Wrick Dunning, "Miners: Reunion Stories," 1992, Audio Archive.
} 
the applicants, was that they could only benefit from the practical experience they stood to gain. It was also a good way for the company to discover if a prospective staff member and long-term resident would be a good fit for the operation and the community.

The regular employees who worked underground, in the mill, or in the shops also sometimes changed roles in the course of their employment. John Peterson was a student at Cornish College in Seattle in 1937 when he hiked into Holden from Darrington (over Cloudy Pass, on the crest of the Cascade Range) and got a job doing roofing and flooring on the crew that built the townsite. He went on to work in the mine for a couple of months, ultimately staying at Holden without pause from May to December. Elmer Foster also worked as part of the construction crew, and later came back after college to work as an engineer. ${ }^{14}$ Like the salaried professionals on staff, regular employees gained roles of increasing responsibility through demonstrating their willingness to do somewhat less important or less glamorous work. William Sartain was 21 years old when he first went underground as a mucker. He later learned how to drill, lay pipes, and set timbers in the mine. Ed Miles, who arrived at Holden in 1941, worked as a switchboard operator, a carpenter, a diamond driller, and a mill worker before becoming an assistant chemist, in which role he wrote the assay report for the last shipment of concentrate in $1957 .^{15}$

The Holden operation paid its workers well. A 1951 Chelan Valley Mirror article reported that "total wages paid during 1950 were $\$ 1,555,247.69$. Names on the payroll averaged 363 and the average number working per operating day was 325 . Wages averaged $\$ 15.05$ per day and yearly incomes averaged $\$ 4,785.37$." By contrast, the

\footnotetext{
14 “Miners Reunion 1996: Remembrances with Larry Penberthy,” 1996, Audio Archive; John Peterson, "John Peterson Interview," 1982, Audio Archive; Elmer Foster, "Some Memories of Early Days at Holden," 1984, Audio Archive.

${ }^{15}$ William \& Theda Sartain and Bill Dierks, "Holden History 1948-1954," 1984, Audio Archive; Dorothy \& Ed Miles, "Holden Village as a Mining Town," 1980, Audio Archive.
} 
average yearly income for metal miners in the US that year was $\$ 3,608 .^{16}$ According to a wartime government report, basic expenses at Holden for a dormitory dweller were limited to $\$ 1.80$ per day for room and board (in 1944). The people who worked in the townsite as kitchen workers or waitresses generally made better money than they could have doing the same work elsewhere. Linda Powell Jensen's mother supplemented the family income working as a waitress in the Fountain Lunch, the little diner-style restaurant located at the east end of the recreation hall. When the family left Holden after Mr. Powell had a fatal heart attack, Mrs. Powell signed up to receive unemployment benefits, but the unemployment office found it hard to believe how much she had made working for Howe Sound, and initially tried to deny her commensurate benefits. Mrs. Powell was reluctant to take a new waitressing job, which would have paid less than the benefits and would not have been sufficient to support four children alone. She consulted the attorney (a family friend) who was handling her husband's will. He intervened on her behalf, and she was able to collect benefits until she secured a higher-paying job a few months later. ${ }^{17}$

Except for the management, which included the office workers, the department heads, and the foremen of the mine and mill, all Howe Sound employees were members of the Chelan Miners Union, No. 379. This was the local branch of the International

\footnotetext{
16 "Holden Incomes Among the Highest in State," Chelan Valley Mirror, 26 April 1951. Historical Statistics of the United States: Colonial Times to 1970 (U.S. Department of Commerce, Bureau of the Census). The government report listed under footnote 9 mentions 366 employees, including 174 underground workers, 45 mill workers, 41 shop workers, 41 surface workers, 27 townsite workers, and 38 staff members. Either Howe Sound or the government official who wrote the report saw a need for 72 additional men.

${ }^{17}$ Linda Powell Jensen, guided tour, 28 June 2010; Linda Powell Jensen, email correspondence with author, 21 December 2012; "Nonferrous Metals Commission of the National War Labor Board, Statement of Position and Brief of Howe Sound Company Chelan Division, 1944," Howe Sound Company files, Special Collections, Allen Library, University of Washington.
} 
Union of Mine, Mill, and Smelter Workers, which was a founding member of the Congress of Industrial Organizations. The union included all working people in town except the postmaster, who was a federal employee, and the clerks who staffed the small privately-owned grocery store. Even teenage workers, who generally only worked during the summers performing the most menial jobs in and around the townsite, had to become members of the union. This was somewhat awkward for those teenagers whose fathers belonged to the management, such as Bill Phillips. His father told him never to go to a union meeting after his first, the one at which he officially became a member. ${ }^{18}$

Relations between the union and the management seem to have been mixed. Holden was the site of a prolonged strike in 1939. In late June of that year, contract negotiations between the union and the company stalled. Howe Sound offered a wage increase of 50 cents per shift, plus 25 cents per shift, "starting at 10 cents a pound, on each $1 \frac{1}{2}$ cent rise in the price of copper." The company also guaranteed free medical examinations for all workers and a week of paid vacation after one year on the job. The union presumably accepted the latter components of the contract offer, but did not agree with the company on the wages offered, initially demanding a $\$ 1$, then a 75 -cent increase in wages per shift. As the company pointed out, the wages it was offering were better than those paid at the copper mine in Butte, Montana, where living expenses were higher, but the union representatives cited the gold content of the Holden ore body as

\footnotetext{
${ }^{18}$ Bill Phillips, "Holden Mining History,” 2010, Audio Archive.
} 
justification for better pay. When Howe Sound refused to meet this demand, the miners went out on strike. ${ }^{19}$

During the weeks that followed, although the contract negotiations dragged on and the mill stood idle, relations between the workers and the company apparently remained civil. The dorms and the dining hall remained open to the men at the same cost as before. However, most of the men left Holden during the strike, and the majority of those who stayed were family men. By mid-July, the Wenatchee World (which covered the strike closely) expected only the negotiating committee of 12 men to stay for much longer. The union issued 60 cents per day to single men who stayed on site, and $\$ 5.50$ per week to married couples, plus an additional dollar per child. In a July 14 letter to one of his superiors, C.P. Browning, Curzon expressed doubt that the strikers would receive much relief from beyond their local union and other supporters in Chelan.

To Curzon, it was clear that the company must stand its ground. "If the company weakens on this strike," he wrote, "we can expect trouble every year." 20 His position was rewarded when he began to see cracks in the strikers' resolve. In his estimation, the remaining residents of the family campsite were divided between those who favored continuing the strike, those who were unresolved, and those who favored returning to work; he thought that this last group probably composed the majority, but lacked leadership. On July 21, the Wenatchee World reported that the union had proposed that the men return to work while an arbitration committee continue to discuss wage adjustments with the company. Nevertheless, not until August 16 did the men

\footnotetext{
19 "Howe Sound and CIO Attempt Settlement," Chelan Valley Mirror, 6 July 1939; Wenatchee World, "Howe Sound Spars Union," 1 July 1939, "Howe Sound Miners Out on Strike," 7 July 1939; "Mine Parley at Holden Tomorrow," 26 July 1939.

${ }^{20}$ Wenatchee World, "Miners Quit Camp," 10 July 1939, "Miners Deserting Posts at Holden," 12 July 1939, “Long-term Siege Seen at Holden,” 15 July 1939; J.J. Curzon to C.P. Browning, 14 July 1939.
} 
finally vote to go back to work on the company's terms. This came after some minor concessions by Howe Sound, including the switch from a six-day work week to the 13 out of 14 day schedule, which the men presumably wanted for the simple reason that it meant one more day of earned pay. ${ }^{21}$

This episode was costly to Howe Sound, and to the other links in the transportation chain between the mine and the ASARCO smelter in Tacoma. The company was unable to recover the $\$ 20,000$ it paid in freight bills for this period, and some of the employees at the smelter had to be laid off. ${ }^{22}$ However, as Curzon had predicted, by standing firm, and by maintaining civil relations with the workers during the strike, the company discouraged future clashes and apparently kept the respect of most of its employees. Virtually all those who went on strike returned to Holden by the end of August. In a September 5 letter to Browning, Curzon reported that life had more or less returned to normal. There was a field day for the children, an exhibition softball game against a Wenatchee team, and a dance in the recreation hall, at which unionappointed floor managers watched for rowdy behavior. "There seems to be an excellent feeling among the people," Curzon wrote, "and the mine officials report a better attitude underground."23

Although there were no other prolonged strikes following this episode, relations between the union and the company again became confrontational on a number of occasions. Correspondence between Curzon and company president H.H. Sharp reveals

\footnotetext{
${ }^{21}$ Wenatchee World, "Union Will Take First Wage Deal," 21 July 1939; "Holden Mine Settlement Near," 3 August 1939; "Strike-Stilled Mine Reopens Monday," 16 August 1939; J.J. Curzon to C.P. Browning, 18 July 1939.

22 "Workers vote by big margin to come back," Wenatchee World, 16 August 193.

${ }^{23}$ J.J. Curzon to C.P. Browning, 5 September 1939; Wenatchee World, "No Holden Strike!" 12 March 1942; "280 Miners Idled by Holden Strike," 28 October 1954.
} 
that contract negotiations could be drawn out and acrimonious at times. The miners almost struck again in March 1942, once more because of disagreement over wages. A bizarre situation involving a group of contractors led to a brief, impromptu strike in February 1946. The Morrison-Knudsen company had been contracted to work on sinking a new shaft in the mine. Following a dispute over whether these men, whose local union belonged to the AFL, would be allowed to work in a CIO mine without switching their affiliation, a group of Morrison-Knudsen employees refused to go to work over an alleged lack of commissary sugar for their coffee. Without any direction from their union leaders, the Howe Sound workers joined them in a sympathy strike, using the opportunity to demand more and better food in the dining hall. The company eventually got the situation under control by cancelling the Morrison-Knudsen contract and requesting that the local union president state publicly that a strike was not in effect, and that the men should return to work. In a letter to Sharp, Curzon expressed a low opinion of the local union leadership, blaming it for allowing the men to "blindly [follow] the few and [stay] away from the job."24

Curzon could express his exasperation with the union in very stark terms. In another letter, during a period of tense contract negotiations in November 1950, he wrote to Sharp: "Negotiations have now developed into a show down between the Union and management as to who is going to run the property. Company negotiators need backing now, otherwise we will lose the respect of our employees who in the final analysis seem to understand and appreciate one factor only, force...Although you may not agree with

\footnotetext{
${ }^{24}$ J.J. Curzon, "History of Labor Negotiations, November 1945 to December 1947. Howe Sound Company - Chelan Division, Holden, Washington"; J.J. Curzon to H.H. Sharp, 22 February 1946; "Miners Strike Over No Sugar," Wenatchee World (?) 21 February 1946; A.M Coker (Morrison-Knudsen General Superintendent) to G.A. Griffin, 21 February 1946.
} 
us, we would like to see this dispute go all the way to strike action if necessary in order to teach them a lesson." Around the same time as these negotiations were taking place, a union dispute with the owners of the tavern in Lucerne led to talks between the company and union as to whether the sale of beer in town would be allowed. It seems that most of Holden's inhabitants opposed this move, but, as Curzon wrote, "they appear reluctant to stand up and speak their mind before the single men in the dormitories who apparently run the Union." It is difficult to determine the accuracy of these impressions of the General Manager without making a more in-depth study of labor relations at Holden, but it is interesting that he singled out the dormitory inhabitants as the primary force behind the union. As the most transient residents, they arguably stood to lose the least by striking or otherwise impeding the operation. ${ }^{25}$

\section{The General Manager}

At least within the confines of the valley, the General Manager occupied the position of highest authority, both over the mining operation and over the community in general. For most of the operation's history, J.J. Curzon held this position. Bill Phillips describes him as "a fairly strict person," generally aloof, but interested in his employees' welfare. His correspondence with colleagues and superiors supports this description. Among the company files, there is a letter to the Registrar's Office at the University of Washington, in which he urged the office to reconsider the application of a young employee who had been rejected because of a low high school GPA. Curzon cited the employee's interest in metallurgy and his work experience as potential for advancement

\footnotetext{
${ }^{25}$ J.J. Curzon to H.H. Sharp, 14 and 29 November 1950.
} 
in the mining industry. ${ }^{26}$ In this and in other instances, the management showed its interest in assisting young people.

The paternal role of the General Manager also made itself apparent when Curzon exercised his authority to resolve disputes between neighbors. In early 1949, he received complaints from some residents of the company apartments (located in Dorm 3) about their loud-talking, foul-mouthed neighbors, as well as a separate complaint about a couple who refused to take part in cleaning the bathrooms and other common areas. Curzon resolved the latter problem by calling the husband of the couple into his office and telling him to move out within three weeks. Curzon's correspondence reveals that he also had the pulse of the social life in the community. Commenting on the reasons for an employee's imminent departure in a letter to Sharp, he wrote: "Earl Sackett...is undecided on just what he wants to do...Mrs. Sackett has never cut as wide a swath in the social whirl here as she could have liked."27

However, the General Manager was far from the only person of authority within the operation. He was supported by several other important figures, including the mill and mine superintendents. At various times, these positions were held by H.A. Pearse, Victor Zanadvoroff, John Bley, Ed Haddon, Mike Defoe, and Wellington Phillips. They, the General Manager, and other company officers provided the leadership needed to hold Holden together as a commercial enterprise, and as an isolated community.

IV. Holden Neighborhoods: Townsite, Winston Camp, Honeymoon Heights

\footnotetext{
${ }^{26}$ Linda Powell Jensen \& Bill Phillips, interview with author, Seattle, Washington, 25 July 2012; J.J. Curzon to Frances M. Willard (UW Office of the Registrar), 10 November 1948.

${ }^{27}$ J.J. Curzon, "Notice to Residents of Company Apartments," 8 February 1949; Letter from 4 women in the company apartments to J.J. Curzon, 26 April 1949; J.J. Curzon to H.H. Sharp, 26 February 1946.
} 
Within the greater Holden community, there were general divisions that corresponded to the different places in which the residents lived. Besides the central, company-built townsite, there was Winston Camp, just to the west of the vehicle bridge, and Honeymoon Heights, located on the mountainside above the level of the mine portal. The former was where most of the married men and their families lived. Some families also lived at Honeymoon Heights, though, as its name implied, its first residents during the Howe Sound era were newly-weds, some of them being rookie engineers and their college sweethearts. In that remote valley, Winston and Honeymoon Heights were as close as Holden came to having suburbs, but they were not so far removed from the main camp, its activities, and the mining operation itself that they could be considered separate communities. Lucerne, too, became something of a bedroom community to Holden during the mining years, but its history of human habitation goes back much further than Holden's, and Howe Sound had little control over what happened there besides the loading and unloading of concentrate, equipment, and supplies at the company dock. It should be considered a separate community.

It is somewhat difficult to determine Holden's average population during the mining years, since the community was in a constant state of flux, probably with a few single men arriving and a few departing every week. Most surviving residents mention a population of between 600 and 650 people. However, Bill Phillips compiled a table based on the 1940 census, which lists 374 townsite residents, (46 in the chalets, 328 in the dorms), 172 Winston residents, and 37 Honeymoon Heights residents, for a total of 583 residents. This was fairly early in the town's history; Winston expanded from 45 to 82 homes within the next few years, and eventually to 101. Phillips estimated that the 
population of Winston could have increased by as many as 150 people by the end of 1941 , bringing the total population of Holden to well over $700 .^{28}$

The townsite was home to both the lowest and the highest strata of Holden's corporate and social hierarchy. The men who lived in the dormitories were the most transient workers. The vast majority did not have high school diplomas, and many did not even have an eighth-grade education. On the other hand, the 1940 census lists 16 men with college degrees who lived in the dorms; they worked as engineers, warehousemen, muckers, mill workers, pipefitters, and diamond drillers. Although the dorms were designed for single men, many married men lived in them, too. Of the 119 dorm residents whose marital status was recorded in the census, 42 were married, 63 were single, 9 were divorced, and 5 were widowers. Some of the married men were waiting for a house in Winston or Lucerne to become available so they could bring their families up. William Sartain lived in a dorm until his wife, Theda, was able to join him, at which time they moved into a cabin in Lucerne. They later moved into a dormitory apartment in the townsite, and eventually, with their two children, to a three-bedroom home in Winston. The dormitory apartments were converted from ordinary two-man rooms on the lower floor of Dorm 3 sometime in the later years of the operation. Otherwise, with the possible exception of one floor that may have been set aside for women at one point or another, the dorms were off-limits to women and children. ${ }^{29}$

The single men ate in the dining hall, located on the main level of the Hotel building. Howe Sound fed its workers well. Dorothy Rodgers Miles, who worked in the dining hall as a dishwasher and later as a cook, recalled breakfasts regularly consisting of

\footnotetext{
${ }^{28}$ Bill Phillips, "Holden 1940 Census" \& email correspondence, 25 September 2012.

${ }^{29}$ Miles interview, Audio Archive; Sartain interview, Audio Archive; 1940 U.S. Census.
} 
dry and hot cereal, toast, rolls, bacon, sausage, ham, eggs, coffee, milk, and tea; and dinners consisting of canned and fresh vegetables, varying meat dishes, soup, cake, pie, cookies, fruit, and salad. Aside from the presence of female kitchen workers, this, too, was a predominantly male zone. Though women and families were allowed to eat in the dining hall, they rarely did so. Single men or families who wanted more of a restaurant experience had the option of eating at the Fountain Lunch, located in the southeast corner of the rec hall building. It mostly served burgers and milkshakes. ${ }^{30}$

By contrast to the dorm residents, those who lived in the chalets were among the longest-term residents of Holden, and they included the General Manager, the office manager, the superintendents of the mine, mill, and shops, some of the engineering staff, and some of the office workers. There were 12 family-style chalets; Chalet 3 housed bachelor engineers. Chalet 2 served as a guest house, typically reserved for visiting Howe Sound company officers, and also for visitors from universities and other companies who came to learn more about Howe Sound's methods. ${ }^{31}$ Who lived in which chalet was a reflection of position and rank within the operation. Certain houses were assigned to certain positions, and, generally, the lower-numbered houses (corresponding to a lower position on the hill), belonged to employees of higher rank, though not necessarily in a consistent order. Chalet 1 , which borders the road, was the General

\footnotetext{
${ }^{30}$ Ibid. Miles recalls that the men complained about the lack of variety in their meals despite the general quality and abundance of the food served. The dining hall is also referred to as the mess hall by many sources, but has been called the dining hall throughout the Village era.

Although the current Village Snack Bar, which occupies the same space as the Fountain Lunch, only offers ice cream and milkshakes, it has more seating than its predecessor. The area at the southern end, currently occupied by chairs and tables, used to be set aside for storage. According to Linda Powell Jensen, the downstairs space known as "the Lift," which is now used mostly for music and talent shows, was freezer space for the Fountain Lunch.

${ }^{31}$ The houses in the townsite were not referred to as chalets during the mining days, but are called such here for the sake of consistency.
} 
Manager's house. Chalet 4 seems to have been the house of the mill superintendent, and Chalet 7 was assigned to the mine superintendent. Chalet 5 was assigned to the superintendent of the mechanical and electrical shops; Chalets 8, 10, and 11 were assigned to engineers; and Chalets 6, 12, and 13 were assigned to office staff members. Whether they were inclined to do so or not, men and their families were required to move from one of the other neighborhoods to a chalet upon promotion to a staff position that came with one, or from one chalet to another lower down on the hill. The Bleys, for example, moved from Honeymoon Heights to Chalet 7 when John Bley became mine superintendent and J.J. Curzon, who had held the position of Chief Engineer, was promoted to General Manager, requiring him and his family to move into Chalet $1 .^{32}$ Howe Sound's use of this housing system emphasized the importance of certain staff positions, creating a visible hierarchy within the townsite.

One way in which Holden differed from the stereotypical company town was that it featured a number of privately-run businesses, and the company store was not a significant factor in the life of the community. These businesses were located in townsite buildings. A company commissary occupied the current guest laundry facility at the lower west end of the Hotel building. It eventually gave way to a dress shop, run by Helen Bell, who (according to Linda Carlson) started her business in a spare room of her Winston home. The store most frequently mentioned by former residents was Fred Wigbers' five-and-dime store, located in the basement of the Hotel. Wigbers, who became a storekeeper after he was blinded in a mining accident, sold fishing gear, soap, toothpaste, shaving lotion, magazines, comic books, paperbacks, candy bars, gum,

\footnotetext{
${ }^{32}$ Harriet G. Wilbour, "Residents of the Houses in the Circle at Holden," diagram; Bley interview, Audio Archive.
} 
newspapers, and other small items. Although Howe Sound gave Wigbers the space he needed, Linda Powell Jensen and Bill Phillips believe that his store was not part of the company operation. The store was next door to the post office, run by postmaster $\mathrm{Al}$ Holzhauser. The post office was the only place that could not accept the Howe Soundissued tin money used as currency in town. Employees could draw \$5 worth of 50 cent tin pieces at the grocery store as an advance on their paycheck. ${ }^{33}$

Residents ordered groceries from stores in Chelan (often in bulk), which arrived a couple of days later on the company barge. In Winston, a company truck delivered the orders house to house. However, in 1946, Howe Sound invited William T. Price, owner of the Cash \& Packit store in Chelan, to open a store at Holden. In addition to groceries, the company stipulated that the new store had to carry work clothes and some of the equipment needed by the men in the mine, but could not carry any items that would bring it into competition with Wigbers' store. Price accepted the invitation and opened the new store on the lower level of Dorm 6 (the space currently occupied by the Village carpentry shop) in June 1947. It was equipped with large walk-in coolers for meat and vegetables. Although the store seems to have been a success with Holden residents (despite the fact that dairy and produce still suffered in transit), it ultimately proved a financial burden to Price because there was little opportunity to increase his profits with such a limited clientele. He sold it to Peter Rabbit in 1955, under whose ownership it remained open until the mine's closure two years later. ${ }^{34}$

\footnotetext{
${ }^{33}$ Linda Powell Jensen, guided tour; Carlson, 112; Linda Powell Jensen \& Bill Phillips, email correspondence with author, 10 October 2012. Linda Powell Jensen and Bill Phillips both state that the tin money was never referred to as scrip while they were living at Holden.

34 “W.T. Price Opens Store at Holden," Chelan Valley Mirror, 12 June 1947; Grant H. Birmingham, "Holden Store," Holden Village Portal Museum document.
} 
Winston, located a few hundred yards to the west of the townsite, also included the houses of many long-term residents. Like the townsite, the land Winston stood on was leased from the Forest Service. The neighborhood got its name from the company Howe Sound contracted to clear and develop the site and possibly build some of the original houses, Winston Brothers Construction Company, of Minneapolis. ${ }^{35}$ The later houses were mostly built (and sometimes designed) by the residents themselves. Each resident paid Howe Sound $\$ 20$ per year to rent a 50 by 100 -foot lot. Although the residents were allowed to sell their houses whenever they left Holden, they could not sell them for more than their original cost and the value of any subsequent improvements. Workers had to put their names on a waiting list for the opportunity to buy a vacant lot in Winston. Miner D.A. Rodgers put his name in to buy one in 1940, but gave up his spot during the uncertainty of the 1939 strike, though he eventually secured a lot and built a home on the lowest row of houses (of which there were five, divided by three roads running parallel from east to west). After all the lots had been bought and developed, would-be residents had to wait for someone to sell and move out. The wait could be long; Linda Powell Jensen's family lived in Chelan for a year and a half while her father lived in a dormitory, waiting for his chance. ${ }^{36}$

More than any other part of the community, Winston looked and felt like it could be a neighborhood in any other small American town. The working residents of Winston represented nearly every work area and level of responsibility within the Holden operation, including staff employees whose positions did not require them to live in the

\footnotetext{
${ }^{35}$ Winston Bros. also worked on Seattle City Light's dam at Diablo, another company town in the North Cascades. Paul C. Pitzer, Building the Skagit (Seattle: The Galley Press, 1978), 43.

${ }^{36}$ Carlson, 28; Miles interview, Audio Archive; Linda Powell Jensen, interview with author, Holden Village, 5 July 2010.
} 
chalets. These included the transportation supervisor, some office workers, and some members of the engineering staff. The average level of education among the adult residents was higher than that of the dorm residents, but lower than that of the chalet residents and residents of Honeymoon Heights; more than half of those listed in the 1940 census had at least a high school diploma. Winston was home to the most families, and the largest families. ${ }^{37}$ The Leavitt-Holmes family included several workers, among them Ike Holmes, ore truck driver; his sister, Nadeen, telephone operator; his sister, Winnie, cook/waitress; and brother-in-law, Lewis Leavitt, machinist. Additionally, Ike's sister, Retha (Leavitt's wife), and mother, Nora, worked as seamstresses, and his brother, Billy, ran the meat department in the grocery store. Other large families included that of D.A. Rodgers, who had 12 children, though some were grown up by the time the family moved to Holden. Theirs was one of the largest houses in Winston. ${ }^{38}$

At least a few older, childless couples lived in Winston. Among them were "camp characters" George and Annie Folk. George Folk supposedly made most of his income at the gambling tables in the basement of the recreation hall. Annie Folk owned 17 cats by the end of the mining years, and when the couple moved away after the mine's closure, she left all but a couple of favorites behind in a house filled with open cat-food containers. Other residents owned dogs, some of which were allowed to wander about the community. Aside from the ore trucks on the main road, they encountered few perils in the way of traffic. A few residents of Winston had cars or pickups, which Howe Sound transported in and out on the company barge at no expense to the owners, but

\footnotetext{
${ }^{37} 1940$ U.S. Census

${ }^{38}$ Miles interview, Audio Archive; Darlene Leavitt, "The Holden Miner: Memories from the Mining Years," March 2011 issue.
} 
during the winter almost all private vehicles except those belonging to select managers and members of the safety and transportation crews were put in a garage, parked in Lucerne near the company dock, or sent downlake. ${ }^{39}$

The community was not entirely cut off from outside media. Two newspapers, the Spokane Spokesman-Review and the Seattle Post-Intelligencer, came in every day by the regular passenger boat, and were delivered to subscribers in the townsite and Winston. Those who had radios could listen to stations from Seattle (at night) and Spokane. In the last years of the operation, a few families even had televisions. There was a receiver set up high on Copper Peak, which picked up two or three Spokane channels by capturing signals reflecting off the glaciers on Mt. Bonanza to the northwest. However, the reception was poor. Although former residents have often mentioned that they had access to television, and television probably generated neighborly gatherings in the few homes that had sets, it does not seem to have been a significant factor in the life of the community. ${ }^{40}$

Honeymoon Heights was the oldest Holden neighborhood. Indeed, as a place of human habitation it predated the town itself. It had been the campsite of J.H. Holden and his men, and had also been the location of Howe Sound offices and bunkhouses in the years between Holden's death and the completion of the townsite in 1938. Situated on the slope of Copper Peak, about 200 feet west of one of the upper tailings piles, Honeymoon Heights was more removed from the townsite than Winston, but much closer to the mine portal. It was composed of 15 houses in 1940, and Bill Phillips estimated that

\footnotetext{
${ }^{39}$ Linda Powell Jensen, guided tour, 28 June 2010; Miners Reunion, "Family Houses and Community During the Mining Days: Slide Show \& Discussion," 2004, Audio Archive; Bill Phillips, email correspondence with author, 4 December 2012.

${ }^{40}$ Miners Reunion, Audio Archive.
} 
a total of 17 families lived there during its time as a Holden neighborhood. In terms of its residents, Honeymoon Heights was the youngest neighborhood, and the best educated. In 1940, 13 out of 32 adult residents had bachelor's degrees, and only one did not have a high school diploma. Phillips' analysis of the 1940 census comes up with an average age of 28, compared with 32.5 for Winston, 33 for the dormitories, and 40 for the chalets. ${ }^{41}$

Honeymoon Heights was abandoned in the fall of 1946. As Christine Plimpton noted in her thesis, maintaining the site proved problematic for Howe Sound. It was difficult and time-consuming to transport basic supplies and large items up the mountain. Due to its proximity to the mine, the neighborhood often had to be evacuated when there was blasting underground, regardless of the time of day. Most importantly, Honeymoon Heights lay between two avalanche chutes, one of which bisected the only road to the neighborhood. After the company made the decision to abandon the site, its last residents moved to Winston, and the remaining structures were dismantled or burned in $1948 .^{42}$

Howe Sound provided the residents of these neighborhoods with a number of public utilities and services free of charge, including garbage collection. As a general rule, all kinds of waste, including household waste collected from cans set by the street in Winston, ended up in a pit in the tailings. The company did the same with the contents of the septic tanks (one of which was located in the woods behind Chalet 1), which were first emptied manually, but later pumped out. The company burned some waste in a large incinerator located somewhere near the mill structure. Linda Powell Jensen recalls that

\footnotetext{
${ }^{41}$ Ibid.; Bill Phillips, "Holden 1940 Census"; 1940 U.S. Census

${ }^{42}$ Christine Plimpton, An Ethnoarchaeological Study of Honeymoon Heights (Unpublished M.A. thesis, 1984), 19. Today, the site is almost completely overgrown, but the foundations are still visible.
} 
her father used the incinerator to cremate the remains of the family dog, which died after eating poison. ${ }^{43}$

There was limited telephone service. Within the community itself, telephones were reserved for emergencies and business purposes. They were located in the offices, the home of the transportation supervisor, the home of the fire chief, the homes of the shift bosses, two boxes in Winston, and superintendent staff houses. All calls to the outside had to be relayed through the company office in Chelan, and only one call could be made at a time. This did not deter one worker from proposing to his girlfriend by telephone. The company officer in Chelan, Ansel Snodgrass, relayed the proposal to the girl, who said yes. ${ }^{44}$

Electrical power was both the only public utility that was not free to all residents and the only utility that was not provided directly by the company. Howe Sound paid for the installation of about 40 miles of transmission lines all the way up the east shore of the lake from the Chelan suburb of Manson; the hydro dam at the extreme southern end of the lake generated the electricity. The lines terminated at a substation on the south side of Railroad Creek, near the mine portal, from which point power was distributed throughout the community. Winston (and presumably Honeymoon Heights) homeowners paid the company one cent per kilowatt used. ${ }^{45}$

The company relied on a steady flow of power to keep its operation moving at all times. Where the lines spanned the lake, near Lucerne, they were once struck by a student pilot flying a float plane. Miraculously, both the lines and the pilot survived the

\footnotetext{
${ }^{43}$ Linda Powell Jensen, interview with author, 5 July 2010; J.J. Curzon to H.H. Sharp, 17 September 1948.

${ }^{44}$ Linda Powell Jensen, guided tour; Bley interview, Audio Archive. Linda Powell Jensen, email correspondence with author, 21 December 2012.

${ }^{45}$ Carlson, 28.
} 
collision. Commenting on this incident in a letter to an aviation official, Curzon wrote:

"The importance of uninterrupted electric power for this property cannot be overemphasized... Only enough standby power is available to keep the camp lighted, to operate the heating units in the mill to prevent everything freezing up, and to attempt to keep the mine pumped out to prevent flooding. There is not enough standby power to do all this and still maintain service to the 112 families of the community." Power outages occurred from time to time, but the company was prepared for them. During a nine-hour outage on July 18-19, 1950, which Curzon called "one of the longest on record," a new backup unit kept the town lit and the mine pumps active until the cause of the outage, a lightning-struck line in Manson, could be repaired. ${ }^{46}$

\section{Community Life: Recreation, Religion, \& School}

James Allen described entertainment in the average company town as being "of the homemade variety, with dancing, baseball, and school activities providing the main community recreational program. ${ }^{, 47}$ For the most part, this description rings true when applied to Holden. It is important to note that, although the management was interested in maintaining a happy town, the company was not directly responsible for organizing most recreational activities. This was the responsibility of the Community Club, which the company managed for one month in 1938 before turning it over to a group of officers elected by the community. All employees supported it with 75 cent monthly fees, which went toward new equipment, maintenance, and library subscriptions. Howe Sound

\footnotetext{
${ }^{46}$ J.J. Curzon to Joseph J. Princen (Aero Inspector, CAA), 6 January 1945; J.J. Curzon to H.H. Sharp, 22 July 1950

${ }^{47}$ James B. Allen, The Company Town in the American West (Norman: University of Oklahoma Press, 1966), 94.
} 
provided and maintained the recreational hall, which it furnished with light, heat, and water. ${ }^{48}$ This building was at the heart of most organized community activities. The main floor included a gym, a circulating library, and the Fountain Lunch. The basement included a bowling alley, a pool hall, and a room for gambling, the last of which was offlimits to anyone under 21. In addition to poker and pinochle tables, the basement held a number of slot machines, which helped pay Community Club expenses, among them the tradition of giving each village child a Christmas present. This tradition had to be scaled back in 1952 when the use of slot machines for non-profit purposes, which had previously been exempt from a general prohibition against slot machines in Washington, was ruled unconstitutional by a state Supreme Court decision. The Community Club still gave small children presents, but the older ones had to be content with boxes of candy. ${ }^{49}$

The gym served as a basketball court, a movie theater, and a dance hall. The company showed films three times a week. Each week included one adult film, one kidfriendly film, and one family film. The company ran the movie concession, but 10 percent of the proceeds from each viewing went to support the Community Club. Dances included the annual New Year's Eve Mucker's Ball, which the company hosted. Although anyone of high-school age or older could attend, dances were effectively closed to single men. It was not easy for a man to find a date at Holden. There were very few single women in town, and any miner who brought a date from outside the community

\footnotetext{
${ }^{48}$ The Holden Miner, 15-22 March 1948.

${ }^{49}$ Linda Powell Jensen, guided tour, 28 June 2010; "Background on Gambling in Washington," accessed 23 December 2012, http://www.wsgc.wa.gov/history.asp.
} 
usually had a hard time finding her a place to stay. Women were not allowed to stay in the dorms, and there was limited space in the Hotel rooms above the dining hall. ${ }^{50}$

The gym also served as a makeshift church sanctuary. Holden did not have a fulltime minister, but outside ministers made regular visits, which the company encouraged. When an Episcopal minister from Wenatchee moved on to another parish after years of monthly visits to Holden, Curzon wrote to the man's former church, urging its members to choose a replacement who would be willing to continue the visits. According to Ed and Dorothy Rodgers Miles, a Catholic priest came to Holden every six weeks or so. Given the limited options, many non-Catholics attended his services. In the 1950s, Howe Sound carpenter Brad Morgan led weekly services. After leaving Holden, he eventually became an ordained minister. ${ }^{51}$

Bowling, basketball, and softball were the most popular sports. The community took all three very seriously, and there was competition both between teams formed within the community and against teams that came in from Chelan, Wenatchee, or elsewhere. The bowling alley had four lanes and a hand-loaded system for resetting the pins. Holden had a resident bowling instructor, and the company employed a few people as pinsetters. Holden rec hall manager Tom Blythe eventually became the manager of a bowling alley in Wenatchee. At least once, he brought both men's and women's teams back to his former workplace to compete against Holden's best. The winning teams of

\footnotetext{
${ }^{50}$ Linda Powell Jensen, guided tour; Carlson, 90. To protect the gym's wooden floor against street shoes, the miners covered it with protective canvas whenever a non-athletic event took place there. The Lutherans did not continue this practice. Linda Powell Jensen remembers hesitating to go in when she first reentered the space wearing street shoes upon her return to Holden during the Village era.

${ }^{51}$ Linda Powell Jensen, guided tour; Frye interview, Audio Archive; Miles interview, Audio Archive. There is evidence that other ministers came to Holden from time to time. Jack and Betty Frye once rented an upstairs room of their house in Winston to an itinerant preacher.
} 
the men's and women's leagues usually went to Chelan to compete in regional championships. $^{52}$

Only the basketball team did much traveling outside Holden. At some point in the late 1930s, it won the state amateur championship. Holden sometimes hosted baseball/softball teams from the outside, including an Air Force team from a base in Ephrata. However, most games were played between teams representing different Howe Sound work areas, including the office workers and the managers. Even J.J. Curzon played. Fire Chief Niles Sims maintained the field, located a few hundred yards to the west of Winston. (At least once, he berated a group of boys who had the audacity to play on the diamond right after he dragged a screen over it with his pickup and put in fresh chalk lines for a game the next day). ${ }^{53}$

Non-organized activities included many that are still popular at Holden today. Men and boys hunted, trapped, and fished, both for recreation and for supplementing family diets with fresh meat. Deer and bear were common game in the valley. At least once, a trigger-happy miner shot a bear in the townsite. There may also have been cougar hunting. Nearby Domke Lake's resident trapper, Gordon Stuart, was an accomplished cougar hunter. Cougars are elusive creatures, but, to this day, they occasionally cross paths with Holden residents. Dorothy Rodgers Miles once encountered a cougar on the road between Winston and the townsite as she was walking to work early one morning. Linda Powell Jensen recalls being forbidden to wander above the highest row of houses in Winston after dark after one resident thought she heard cougar screams in the area.

\footnotetext{
${ }^{52}$ Chelan Valley Mirror, 30 January 1947. The Holden Miner, 22 November 1948; Bill Phillips, email correspondence with author, 4 December 2012.

53 "Softball teams will make trip to Holden Mine," Chelan Valley Mirror, 19 August 1948; Bill Phillips, guided tour; Linda Powell Jensen, guided tour. Today, the field is partly overgrown, while a section of the outfield has been devoted a meditative labyrinth.
} 
Holden children sometimes encountered bears while picking berries, but these encounters usually ended with the bear ambling away. ${ }^{54}$

Naturally, Holden's children had their own activities. Both Linda Powell Jensen and Bill Phillips fondly recall the rope-tow on the slope above Winston, which was used by both sledders and skiers. (Today, most sledding takes place on Chalet Hill. During the mining years, this was forbidden, or at least discouraged, because of the ore trucks and other traffic at the bottom of the hill). There was an active Boy Scout troop, of which Phillips and his younger brother were members. The troop traveled to Camporee events in Chelan and elsewhere in eastern Washington; Howe Sound gave men time off so they could accompany their sons on these outings. There were no Girl Scouts, but there was a Campfire Girls group. (This group met in the existing Forest Service cabin, which stands just north of the vehicle bridge and east of Winston). There were also groups of the junior versions of both organizations, Cub Scouts and Bluebirds. The Campfire Girls had a number of adult leaders throughout the mining years, including Bill Phillips' mother. Another adult who was actively involved was the primary teacher and principal of the Holden school, Florence Field. ${ }^{55}$

Mrs. Field's students typically made up between 10 and 20 percent of Holden's total population. (Enrollment at the end of the mining years was about 120). The school had two or three teachers who taught grades 1-8, occasionally supported by skilled

\footnotetext{
${ }^{54}$ Wrick Dunning, "Miners: Reunion Stories," 1992, Audio Archive; "Kids During the Mining Days," 2004, Audio Archive; Miles interview, Audio Archive. While there have been no cougar attacks in the valley, this writer is familiar with a number of stories about Holden Village residents being stalked by cougars. According to John Bley, there was an agreement between the game department and Howe Sound that any worker who violated the game laws would be fired.

55 "Kids During the Mining Days"; Linda Powell Jensen, guided tour; Linda Powell Jensen, email correspondence with author, 21 December 2012. Field was much loved by her students. When she died in the summer of 2010 at 102, numerous former students attended her memorial service, and most of them spoke about the quality of the education she had given them and how she had influenced their lives.
} 
members of the community who came in to the classroom to share their expertise. The school building originally housed a single classroom; a second was added in 1939, and a third (on the side of original structure) in 1949. The basement was sometimes used as additional classroom space, or for crafts projects, such as leather work, carpentry, pottery, or tin work. With both space and instructors being in limited supply, students of different grade levels attended classes together. After the third classroom was added, the students were taught in three groups: grades 1-2, grades 3-4, and grades 5-8. In the largest classroom, eighth-graders held the privilege of sitting by the windows. ${ }^{56}$ Graduation from the $8^{\text {th }}$ grade was a rite of passage for Holden students because they had to attend high school elsewhere. Some students went to live with friends or relatives while they attended public high school in Chelan, Wenatchee, or more distant cities, while others went to boarding schools, such as Lakeside School in Seattle, Gonzaga High School or Holy Names in Spokane, or Annie Wright Seminary in Tacoma. At least one student spent her freshman year at Holden taking high school correspondence courses. ${ }^{57}$

The Holden school was not part of the Chelan school district. According to a 1937 Chelan Valley Mirror article, Howe Sound petitioned for the new school to be included in the district, but eventually withdrew this petition and decided to create and maintain its own separate district. As far as the students were concerned, this move did not have a negative effect. Former Holden students have stated that the quality of the education they received, which included instruction in such practical subjects as basic

\footnotetext{
${ }^{56}$ Miles interview, Audio Archive; Linda Powell Jensen, guided tour; Miners Reunion, "Family Houses and Community During the Mining Days: Slide Show \& Discussion," 2004, Audio Archive; Bill Phillips, email correspondence with author, 4 December 2012; Linda Powell Jensen, email correspondence with author, 21 December 2012.

${ }^{57}$ Chelan Valley Mirror, "Holden Students Observe Year's End Ceremonies," 6 June 1952, "Holden Students Go Back to Their Studies Now," 28 August 1952; Carlson, 62.
} 
carpentry (for both boys and girls), gave them an advantage over their peers when they started high school on the outside. Howe Sound had a clear motivation for providing the community with a good school: without one, it was less likely to attract family men, who were generally perceived as being more stable employees than bachelors. The same logic drove Weyerhaeuser's decision to build a school in its lumber town in Potlatch, Idaho. ${ }^{58}$

Howe Sound also supported Holden's children in other ways. Although no one under 18 was allowed in the mine for any reason, the company practically guaranteed work of some kind to older teenagers and college students home for the summer. As a rule, the jobs available to them were not very pleasant. For example, Bill Phillips spent part of one summer on a crew pumping out the town septic tanks. As in most American towns of the time, there were opportunities for younger children to earn a little money doing odd jobs. Linda Powell Jensen and her friends started earning money as babysitters when they were as young as nine or ten. The Phillips brothers delivered the Seattle Post-Intelligencer to residents of the chalets and dormitories. ${ }^{59}$

\section{Women at Holden}

Howe Sound offered employment opportunities for women, too, but limited ones. Most surviving personal accounts left by working women tell of jobs in the dining hall or the Fountain Lunch. Nearly all the working women were either the wives or daughters of miners, and some were both. Betty Frye was the daughter of a company machinist who started working in the dining hall in 1945, when she was 17. She and her husband, Jack

\footnotetext{
58 "Howe Sound Plans School at Mine," Chelan Valley Mirror, 18 August 1937; Keith C. Petersen, Company Town: Potlatch, Idaho, and the Potlatch Lumber Company (Pullman: Washington State University Press, 1987), 96.

${ }^{59}$ Miners Reunion, "Family Houses and Community During the Mining Days: Slide Show \& Discussion," 2004, Audio Archive; Linda Powell Jensen, "Holden Life 1951-1955," 1990, Audio Archive; Bill Phillips, guided tour.
} 
Frye, met two years later when the latter came to Holden, where he worked underground, and later in the machine shop, presumably alongside his father-in-law. Betty continued to work for some time after their marriage, though perhaps not after the birth of the couple's two children. Other couples, including Ed Miles and Dorothy Rodgers Miles, also met at Holden and stayed for years after their marriage. However, according to an edition of The Holden Miner newsletter, only one couple, Roy and Marge Schoeppach, actually married at Holden, on January 15, 1943. They were married in a private home by a minister who was living at Holden at the time. Apparently, only Roy's parents were Holden residents; thus, it seems likely that the Schoeppachs did not meet at Holden. In any case, they did not stay long after their marriage. ${ }^{60}$

Being a mother at Holden involved some special challenges. Foremost among these was the fact that Holden's isolation made giving birth there a risky proposition. A few women did so, either by choice or because they went into labor sooner than expected. The first birth at Holden occurred in December 1942 when a storm prevented the mother, a Lucerne woman, from being taken downlake. She was brought to Holden, where the company physician, Dr. Harris, delivered the baby with the assistance of three midwives. Generally, the company doctors were unwilling to deliver babies because of the risk of complications. However, from 1955 to 1957, Dr. William Miller and his wife, Marie, a nurse, handled at least 11 deliveries, and possibly as many as 15 . According to Linda Powell Jensen, there were at least 17 babies born in the Holden hospital. But most women chose to play it safe and went out to Chelan, Wenatchee, or Spokane as they approached their due date. They usually had to go without their husbands, who could not

\footnotetext{
${ }^{60}$ Frye interview, Audio Archive; “The Holden Miner” newsletter, November 1988.
} 
take enough time off to make sure they would be present when their wives went into labor. However, at least one Holden husband took time off to visit his wife in a Spokane hospital shortly after she gave birth, and it is probable that many whose wives gave birth in Chelan did the same. ${ }^{61}$

Especially for those Holden women who did not have jobs (the overwhelming majority), there may well have been times when life in the community proved monotonous, perhaps dauntingly so. However, a variety of women's groups served to combat boredom, including bridge clubs and hospital guilds. (The funds generated by the guilds went to support the Chelan Hospital and the Children's Orthopedic Hospital in Seattle). Incredibly, some residents endured the isolated setting for exceptionally long periods. Linda Carlson recorded that one mother did not leave the valley at all for four years; this may have been the mother of Dorothy Rodgers Miles, who recalled that neither of her parents went out during a four-year period. ${ }^{62}$

\section{Environmental challenges and emergency situations}

While boredom should not be underestimated as one of the challenges of living in such a remote location, Holden residents also lived with more tangible environmental hazards. In winter, the residents had to remain vigilant against avalanches. Besides being a very real threat to vehicles, walkers, and skiers, avalanches sometimes cut off the only route to the outside world, potentially compounding other emergencies. Throughout the year, and most of all during the dry summer months, the physical community was

\footnotetext{
${ }^{61}$ Linda Carlson, "Miners Reunion: Married to the Mine, Women during the mining days," 2004, Audio Archive; Linda Powell Jensen, email correspondence with author, 21 December, 2012.

${ }^{62}$ Carlson, 119; Linda Powell Jensen, guided tour.
} 
highly vulnerable to fire. The company had resources for mitigating these hazards, and for dealing with medical situations and crime. But these resources were limited, illustrating the extent of the Holden community's self-reliance.

Generally, the community took precautions to reduce the risk of avalanche deaths. Both Winston and the townsite were built between major chutes that came down from Martin Ridge. On the road between the two camps, one adult escorted small groups of children across the most dangerous section while another kept an eye on the chutes above. The wisdom of this practice was confirmed by an avalanche that took out part of the footbridge spanning the creek below the mill at some point during the 1940s. The slopes above the mill were also avalanche-prone; and with men working and commuting through this area at all hours of the day, it was there where the risk was greatest. On one occasion, a landslide filled the assay office with mud and ice, though no was hurt. In February 1947, as Alfred Otto was leaving the dry-and-change house after completing a swing shift, he was killed by a slide that carried him 200 feet downhill, burying him deeply enough that searchers failed to find his body for several hours. He remains the only person to be killed by an avalanche at Holden. However, two years previously, there had been another snow-related fatality; a man died from injuries sustained when the snow plow he was driving went over an embankment. ${ }^{63}$

The greatest potential for loss of life and limb lay in the mine itself. On average, there was about one fatal accident per year. In the Holden Portal Museum, there is a list of these deaths, compiled by Linda Powell Jensen from Howe Sound company accident reports and articles in the Chelan and Wenatchee papers. In most of the newspaper

\footnotetext{
${ }^{63}$ Linda Powell Jensen, guided tour; "Alfred E. Otto Killed in Snow Slide at Holden,” Chelan Valley Mirror, 6 February 1947; "Charles P. Kelley Killed at Holden,” Wenatchee World, 27 November 1945.
} 
accounts, the exact cause of death is not given, but there were men who fell down holes or open shafts, men who were crushed by falling rock, and one man who suffocated in an ore bin. Some may have been killed through inexperience; Ernest Jacobs was 19 when he died in 1947, and had been working in the mine for only two months. ${ }^{64}$ However, it should be noted that the operation's safety record was relatively good: no accident claimed the life of more than one man.

There were numerous deaths in the general community, stemming from various causes. The correspondence among J.J. Curzon, his superiors, and the department heads reveals that employee deaths not caused by accidents could be at least as shocking as fatalities in the mine. A few men died of heart attacks. In reaction to one such death, the victim having had no prior health problems, mill superintendent H.A. Pearse wrote: "One would have expected that going up and down the stairs, and the hill to the heights, would have produced such definite reactions as to make him very suspicious about his condition." ${ }^{95}$ The company and the workers were supportive of widows. Beginning in 1939, all employees who had been on the job for at least six months automatically became insured for $\$ 1,500$ without medical examination, and each additional six months of service added $\$ 200$ to their coverage. Additionally, whenever an employee died, Howe Sound put up a list for men to voluntarily have an amount deducted from their paychecks to support the dead man's family. At least some families were allowed to stay on at Holden for a while; after Linda Powell Jensen's father died, her mother continued working at the Fountain Lunch long enough for Linda to finish the school year at

64 "Deaths in the Mining Years," Holden Village Portal Museum document; Chelan Valley Mirror, "Holden Miner's Injuries Fatal; Hurt Monday," 21 August 1947; "Cave-In Kills Miner of Howe Sound Company," 6 November 1941; "L.D. Branscom loses life in mine accident," 16 August 1956; Miles interview, Audio Archive.

${ }^{65}$ H.A. Pearse to J.J. Curzon, 11 February 1946. 
Holden. ${ }^{66}$ Undoubtedly, the deaths that impacted the community most heavily were those of children. One young boy drowned in Railroad Creek, as did another in Lake Chelan during an outing to Lucerne. (A man also drowned in 1953 while fishing at Moore Point, on the other side of the lake). A 1952 polio outbreak infected several children and claimed the life of a 12-year-old girl, who died in a Wenatchee hospital shortly after being evacuated from Holden. In 1943, a 15-year-old Boy Scout bled to death on Mt. Bonanza after falling on his ice-ax. ${ }^{67}$

It was always the policy to evacuate anyone who was critically injured or ill. This had the potential to be very challenging if an accident occurred at the wrong time. Before the advent of helicopter evacuations in the 1950s, the only way to get a sick or injured person out was by the road, and then from Lucerne by boat or float plane. In 1942, a severe winter storm over the lake delayed the evacuation of a critically injured miner, who later died. While this writer is not familiar with any accounts of a medical evacuation being impeded by snow on the road, it could have happened. A heavy

\footnotetext{
${ }^{66}$ Linda Powell Jensen, guided tour; Wenatchee World, 1 July 1939. On the day Mrs. Powell planned to pack and load the family's belongings, she had the help of some of her Winston neighbors, as well as a group of men from the dorms who knew her from their visits to the Fountain Lunch. They brought some beer with them, and on the day that the family unpacked the truck, they discovered a half-full bottle wedged in so tightly that it had not spilled a drop.

${ }^{67}$ Chelan Valley Mirror, "Lad Fatally Injured in Mountain Fall," 12 August 1943; "Holden Girl Succumbs to Polio Attack," 24 July 1952. Bill Phillips, guided tour; Bill Phillips, email communication with author, 4 December 2012. It is uncertain how popular mountaineering was in the community. The Boy Scouts climbed Glacier Peak under the leadership of Scoutmaster Lin Bennett and Copper Peak and Mt. Fernow under the leadership of Jim Sullivan. Bill Phillips, who took part in the Copper climb, does not recall that many miners went climbing in their free time. Perhaps so dangerous an activity was not appealing to men who already exposed themselves to considerable danger working underground, and whose time off was often limited to one day per week. However, there were exceptions; some of the geologists were mountaineers, as were George Bator and his climbing partner, Larry Penberthy, whose many photos of Railroad Creek Valley and the surrounding peaks, taken from various high places, still grace a number of spaces in the Village.
} 
avalanche could isolate the community for days. This was also troublesome because it prevented the ore trucks from delivering their loads to the barge in Lucerne. ${ }^{68}$

However, to handle emergencies, and to deal with less urgent situations, Howe Sound maintained an on-site company doctor and a nurse. The doctor's primary responsibility was to respond to mining accidents, but he was also allowed to run a private family practice on the side. In this regard, medical care was not a public service, but it was provided indirectly by the company. As someone who could bar a man from employment in the mine for medical reasons, or prevent a man from being rehired, the doctor had an impact on the composition of the community. As someone who treated the miners' families in addition to the miners themselves, he could become the focal point for feelings of dissatisfaction toward the company. The various doctors who served the community during the mining years displayed markedly different levels of professionalism and respect for the people in their care. One is the subject of some of the most colorful and revealing items of correspondence in the company files.

Howe Sound preferred its doctors and nurses to be husband-and-wife teams without children, which allowed the company to house them in one of the two apartments at either end of the hospital building, located uphill of the dormitories and just west of the highest-numbered chalets. The hospital was equipped with an office, a room for surgeries, an X-ray room, one single-bed and one four-bed ward, and one room reserved for Dr. Dewar, a Chelan dentist who visited periodically. The first doctor and first nurse were Manly J. Wham and his wife, Muriel. They stayed until September 1942, when Dr. Wham left to become an officer in the Army medical corps. Muriel Wham's successor, a

\footnotetext{
${ }^{68}$ Miles interview, Audio Archive; "Slides, Rain and Snow Add to Difficulties in Holden Community," Chelan Valley Mirror, 24 February 1949; J.J. Curzon to H.H. Sharp, 2 Feburary 1946.
} 
Mrs. Johnson, was married to a Howe Sound geologist, and lived with her husband in one of the two hospital apartments. ${ }^{69}$

Curzon encountered difficulties with Dr. Wham's first two successors. The first, Dr. Harris, who came out of retirement in response to the war, worked at Holden for about two years before issuing an ultimatum: if Howe Sound did not increase his salary by $\$ 100$ per month (from a base of $\$ 500$ per month), he would quit within 10 days. Even if the company agreed to the raise, he would only stay for one more year. In a letter to Howe Sound president H.H. Sharp, Curzon wrote: “None of us care for Harris' attitude during this entire procedure, as he is quite definitely taking advantage of the situation...If Harris was really trying to do a good job it would be an entirely different thing, but he is very definitely trying to do as little work as possible, especially with the families and children."70 Despite his evident disgust with the situation, Curzon seems to have agreed to Harris' terms and retained him well into 1945, probably for the sole reason that finding an acceptable replacement was difficult. The General Manager's files contain a number of letters to and from young doctors with excellent credentials, but few who were interested in practicing in such a remote location.

Eventually, Harris was succeeded by Dr. Theo Gallup. The new doctor cannot have been living at Holden long before he made himself unpopular in the community, for in April 1946, Curzon received a petition from the Chelan Miners Union, which charged Gallup with incompetence, unsanitary practice, excessive fees, lack of courtesy, "requiring the school children here at Holden be vaccinated for smallpox, then sending the parents a bill for the service, and being unable to handle maternity cases." While

\footnotetext{
${ }^{69}$ J.J. Curzon to Dr. William B. Niehus, 25 July 1944.

${ }^{70}$ J.J. Curzon to H.H. Sharp, 31 August 1944.
} 
Curzon cannot have been pleased about these charges, his response to the petition was cool. Including a copy of the petition in his correspondence with Sharp, he wrote: "If the company took any action on a petition of this kind, a precedent would be set whereby the union could petition any other staff employee out of his job, which is something that will not be tolerated by this company. The company's stand in this case is that Dr. Gallup is a staff employee, who is deemed satisfactory for what he is employed for, which is to handle company accident cases." ${ }^{.71}$ In this instance, as in the case of the 1939 strike, Curzon saw a situation that had the potential to weaken the authority of the company and the management if handled in a way that was too accommodating to the workers' demands.

Nevertheless, later correspondence reveals that Curzon was sufficiently displeased with Gallup to try replacing him. In early 1947, the General Manager invited at least one doctor to apply for the position, candidly admitting to the prospective employee that he was doing so without Gallup's knowledge. This effort was unsuccessful. Gallup remained at Holden for another three years, during which time he continued to make problems for himself and the company. In February 1949, an insurance company sales representative sent a letter to Curzon, complaining about Gallup's lack of cooperation in filling out and returning claims forms for Howe Sound employees. Not long after, Gallup wrote an angry letter to a member of the Washington Hospital Service, in which he demanded to know why he was never asked if he was willing and able to qualify as a Blue Cross-eligible physician, even though he knew that he did not qualify because he was not a member of the county medical society. This

\footnotetext{
${ }^{71}$ J.J. Curzon to H.H. Sharp, 22 April 1946.
} 
letter reveals more about Gallup's relationship with the members of the Holden community. Citing his treatment of one employee's daughter for a renal infection, and another employee's baby for a strep infection, he wrote: "In both cases I felt the long trip out to a hospital would be detrimental and treated the children at home. The families were finally awarded the actual cost of the penicillin I administered. Both families were given the impression that was all I should have charged them, with the result that I have made some bitter enemies, and in one case I never was paid.” What Gallup characterized as misunderstandings were probably perceived by the families of his patients as overbilling. ${ }^{72}$

To be fair, Gallup also did some things that rightfully earned him praise from company officials. As Curzon noted, he seems to have been competent in his handling of work accidents, which were, after all, his primary responsibility. In 1949, near the end of his tenure with Howe Sound, Gallup conducted a study to determine the effectiveness of the ventilation systems in the Holden mine. A comparison of new and old X-ray images of several miners' chests showed no evidence of silicosis, a deadly lung condition that appears in men who work in dusty or poorly ventilated mines. Naturally pleased with this conclusion, company president Sharp wrote to Curzon, asking him to thank Gallup for his work. Gallup also played an important role in enforcing the company's policies on containing the spread of disease within the community. When Bill and John Phillips contracted scarlet fever from an unknown source, Gallup and Curzon determined that their father would have to move to a dormitory room until his sons were no longer contagious, thereby discouraging the sickness from spreading to the work force. In the

\footnotetext{
72 J.J. Curzon to Dr. E.R. Murphy, 17 January 1947; Dr. Theo Gallup to C.J. Howe, 7 March 1949; C.J. Kretchmer to J.J. Curzon, 28 February 1949.
} 
end, Gallup was neither fired nor covertly replaced, but himself asked to be replaced in January $1950 .^{73}$

There is less information in the files about Gallup's successors, of whom there were at least six before the mine closed. Of these, four, including Gallup's immediate successor, Jack Carleton, had children. Bill Phillips described Carleton as the "complete antithesis" of Gallup, a personable man who actively involved himself in community activities, including the Boy Scouts, even though his own sons were not old enough to join the troop. His role as the troop's counselor for the first aid merit badge had a strong influence on Phillips' later decision to become a professional first aid provider through the volunteer ski patrol. Carleton and later doctors Paul Mickens and William Miller lived in Chalet 11 with their families. As previously noted, Dr. Miller and his wife were unusual among the company doctor-nurse teams in that they were willing to handle maternity cases. $^{74}$

While avalanches and the hazards of working in the mine were probably the greatest threat to the residents as individuals, there was no greater threat to Holden itself than fire, especially forest fire. The community never lost sight of this, even during the 1939 strike. Minutes from a meeting between union representatives and company officers record Curzon seeking assurance from the union men that those workers who remained in town would be available to respond to fire, and another officer expressing concern about the risk of fire being sparked by hikers or fishermen carelessly dropping cigarettes. Naturally, such risks also concerned the Forest Service, which worked with

\footnotetext{
${ }^{73}$ H.H. Sharp to J.J. Curzon, 6 May 1949; J.J. Curzon, "History of Doctor Deal,” (note); Bill Phillips, email correspondence with author, 4 December 2012.

${ }^{74}$ Bill Phillips, email correspondence with author, 4 December 2012; Harriet G. Wilbour, "Residents of the Houses in the Circle at Holden," (diagram).
} 
the company to prevent and contain forest fire. On at least a few occasions, the Forest Service borrowed miners to fight fires; Curzon's files contain a letter to a local ranger requesting compensation for five employees who spent a day fighting a fire on Tinpan Mountain (the peak to the east of Buckskin), as well as a letter from Forest Service supervisor N.J. Penick thanking Curzon for the loan of 50 miners to fight a fire on Lyall Ridge, near Stehekin. Penick called the men "excellent firefighters," adding that "their performance, when the going is "tough," is a splendid reflection of the cooperation which has always existed between your company and the Forest Service." The loss of 50 men, of course, would have affected the mine's production capabilities after more than a brief period, which Penick acknowledged. ${ }^{75}$

Holden was never directly threatened by a forest fire, but there were smaller fires in the physical community. Surviving incident reports and articles in the Chelan Valley Mirror reflect a range of close calls, minor blazes, and full-blown building fires. A fire started by an overheated radio in Dorm 6 may well have burned a significant section of the building if it had not been extinguished by some off-duty residents. In January 1938, the old bunkhouse in the Miners Camp (later known as Honeymoon Heights), which dated back to the period when Howe Sound was leasing the property, burned down; men were sleeping in the bunkhouse when the fire broke out, but no lives were lost. This was not the case when a Winston home burned down the following year - a young couple and their seven-year-old daughter were killed. A fire destroyed Hal and Florence Field's Winston home in February 1950, constituting a loss of $\$ 5000$. It is interesting to note

\footnotetext{
${ }^{75}$ Minutes from meeting between company (J.J. Curzon, W.E. Taylor) and Union (Corby, McKnight, Kobetich, Bagley), 15 July 1939, Special Collections, Allen Library, University of Washington, Seattle; J.J. Curzon to R.E. Foote (Forest Ranger), unknown date; N.J. Penick to J.J. Curzon, 16 September 1944.
} 
that while the danger of catastrophic fire is greatest during the summer, all major fires in both the mining years and the Village era have occurred during the winter, no doubt because that is when the residents most often use stoves and furnaces. The chalets and the homes in Winston were heated by either wood or oil-fired furnaces. As is the case in the valley today, the Forest Service marked trees along or near the road that could be felled; they were harvested, bucked, and split by the homeowners themselves, or by men they hired. The single men who lived in the dorms could earn extra money this way. The company provided fuel oil to those residents who needed it and deducted the cost from their pay checks. ${ }^{76}$

Howe Sound employed a full-time fire chief. For most of the operation's history, this was Niles “Chief” Sims, who took the job in 1939 after training as a volunteer firefighter in Omak. He acted as the company's contact with the Forest Service. While there were times when Sims had few visible duties, there is no doubt that Howe Sound took the threat of fire very seriously. The company installed sheltered hydrants (hosehouses) throughout the community: six in the townsite, at least seven in Winston, one on the road between the two camps, one along the path running from the creek to the mill, one near the base of the mill, and possibly others on the southern side of the creek. (In winter, one of Sims' jobs was to maintain access to these hose-houses). There were two fire engines, one stationed near the mine entrance, and one at the western end of Dorm 6, directly across the street from the fire chief's office (now the Village garbage dock). During the summer months, at least, the company maintained "a fire-fighting

\footnotetext{
${ }^{76}$ Niles Sims, "Monthly Fire Report," 26 February 1944; "Monthly Fire Report," 4 February 1950; Chelan Valley Mirror, "Buildings Damaged in Blaze at Holden Mine," 27 January 1938; "Family Dies in Fire at Holden Mine," 23 February 1939; Bill Phillips, email correspondence with author, 4 December 2012.
} 
organization consisting of approximately 16 employees." Presumably under Sims' direction, these men held weekly fire drills, at which time they tested hoses and other equipment. The company did not hold drills during the winter "because of the difficulty in draining and drying the fire hose.,"77

Sims also served as Holden's lone law enforcement officer, but he had little to do in this capacity. The few times residents committed serious crimes, outside authorities quickly took over. There were two major acts of theft against the company, the first of which occurred in July 1947 . Two miners stole $\$ 500$ from the rec hall safe or register; they confessed under questioning by two sheriff's deputies who came in from Chelan. Along with a public brawl that took place the same year (which is part of the discussion in the third chapter of this thesis), this incident probably contributed to demands for a local law enforcement official. In January 1948, a Wenatchee World article reported that Holden wanted a justice of the peace and a constable to keep the peace, both of which it got later that month. The county auditor swore in Bob Brown, a former night watchman, as justice of the peace, and Sims as constable. Although Dorothy Rodgers Miles recalled that Sims "never had to do anything," he may have played a role in dealing with the second major theft. In terms of the sum involved, it was much more serious than the first. In August 1949, someone stole $\$ 10,000$ from the company safe. After nearly all the employees had been questioned, the guilty man was caught when it was discovered that he had sewn $\$ 828$ into the lining of his coat. All but $\$ 2000$ of the remaining money (consisting of checks, bills, and silver) was recovered from a number of caches in the woods near the mine. There is an intriguing but slightly confusing account of one of

\footnotetext{
77 “The Holden Miner" newsletter, November 1988; Pat Schonders, interview with author, Chelan, Washington, 15 May 2011; Mitchel, "Report of Chelan Division,” July 1943.
} 
these burglaries in Holden Village's Portal Museum, titled "The Great Rec-Hall Robbery." Written by Sims' son-in-law, Bob Marcum, it relates how Sims followed a coin trail to jars hidden under the footbridge, where he discovered the guilty employee's brass identification token mixed in with the money. Marcum states that this occurred in the summer of 1949, not 1947, which suggests that he either confused the dates of the two incidents or confused the incidents themselves. The first explanation seems more likely; the employee token Sims found would have made it unnecessary to question hundreds of men, as the deputies did during the second incident. The rec hall robbery occurred before Sims officially became constable, but he could have tracked the coins on his own initiative. ${ }^{78}$

As demonstrated by these incidents, Sims' authority was limited. He was involved in the company's response to at least one incident of domestic violence (which almost certainly resulted in the dismissal of the guilty employee), and he probably did what he could to prevent brawls and other disturbances. ${ }^{79}$ But any time there was crime that went beyond this level, full-time law officers came in from Chelan or Wenatchee to deal with it. Professionals also helped handle other kinds of trouble. In early 1950, an unknown employee sent J.J. Curzon an incendiary, typewritten letter. The letter itself was not preserved in the company files, but Curzon implied that it attacked the way the operation was being managed. The General Manager responded by directing one of his subordinates to ask the suspected employee to type a bogus set of instructions on his personal typewriter, so that he could compare the type with that in the letter he had

${ }^{78}$ Chelan Valley Mirror, "Robbery at Holden Recreation Hall," 3 July 1947; "Holden Gets Peace Officers for First Time," 29 January 1948; Wenatchee World, "Holden - 10 Years Without Law Officer Now Wants One," 20 January 1948; "Miner Charged in \$10,000 Theft," 5 August 1949; J.J. Curzon to Ken Brooke, 30 January 1948.

${ }^{79}$ Linda Powell Jensen, email correspondence with author, 21 December 2012. 
received. Upon seeing tell-tale similarities, he sent both pieces to the FBI for a professional opinion. In his letter to the bureau, Curzon wrote that investigation had shown the writer's accusations to be "either outright lies or gross distortions of true facts. The problem then became one of determining who the author of the letter was, because if such people are allowed to remain on our payrolls, trouble will follow without doubt." The FBI confirmed his suspicions, presumably leading to a speedy dismissal for the employee in question. During World War II, the FBI also investigated half a dozen employees whom the management suspected of having pro-Axis sympathies. ${ }^{80}$

\section{Holden During World War II}

Despite its isolation, Holden's experience during World War II was similar to that of countless other towns throughout America. The community was subject to the rationing of food and other basic supplies, though nothing critical to the mining operation (such as fuel oil). Households sent their ration books out to Chelan with their grocery orders and got them back, checked off, with the food when it came in. Soap was among those basic necessities that were somewhat scarce, leading some people to make their own from saved-up lard and oil. The Boy Scouts collected tins for the war effort. A Civilian Defense group trained residents how to respond to air raids. Like other rural communities in Washington and Oregon, Holden was subject to the threat of fire sparked by Japanese incendiary bombs. The Japanese sent bomb-bearing balloons on wind currents across the Pacific in the hope of starting massive forest fires in the Northwest, and also used a seaplane to bomb the woods near Brookings, Oregon, in 1942. For this

\footnotetext{
${ }^{80}$ J.J. Curzon to Ottis V. Kelley, 27 March 1950; Mitchel, "Report of Chelan Division,” (probably February) 1943.
} 
reason, Holden residents were warned not to approach any downed balloons.

Fortunately, the only one sighted during the war turned out to be a weather balloon. ${ }^{81}$

In other ways, Holden's experience during the war was unusual. The copper the mine produced was vital to the war effort. The government froze the price of copper at its prewar price of 11 cents per pound for the duration of the conflict, but paid "bounties" of up to 27 cents per pound to those companies, perhaps including Howe Sound, that could not afford to stay in production at the fixed price. Holden's miners received exemption from the draft as vital war industry workers; thus, the community retained a young, healthy, adult male population throughout the war. J.A. Krug, Chairman of the War Production Board, wrote to Howe Sound president H.H. Sharp: "It is essential that the mine and plant of the Howe Sound Company continue to produce copper at the rate of your present level of production in order to fulfill your share of the overall requirements...I can think of no better way in which the employees of the Howe Sound Company can serve their country at this time than by producing copper." ${ }^{\prime 2}$ Sharp sent a copy of this letter to Curzon, having underlined the last sentence.

In 1945, the head of the Copper Division of the War Production Board, D.L. Forrester, guided the General Manager through a process to insure that none of his workers in the 26 to 29 age group would be drafted, which would have deprived the

\footnotetext{
${ }^{81}$ Miles interview, Audio Archive; "Miners Reunion: Married to the Mine, Women during the Mining Days," Audio Archive; Mitchel, "Report of Chelan Division," (probably February) 1943; "Family Houses and Community During the Mining Days: Slideshow \& Discussion," Audio Archive.

${ }^{82}$ J.A. Krug to H.H. Sharp, 16 January 1945; Navin, 140. The company files include a telegram recognizing Holden's important contribution to the war effort, which reads: TO THE MEN AND WOMEN OF THE HOWE SOUND CO. THIS MESSAGE FROM THE COMMANDER AND CHIEF OF THE ALLIED FORCES IN AFRICA IS RELAYED BY THE WAR DEPARTMENT. OUR FIGHTING MEN STANDING SHOULDER TO SHOULDER WITH OUR GALLANT ALLIES, THE BRITISH AND FRENCH HAVE DRIVEN THE ENEMY OUT OF NORTH AFRICA. IN THIS VICTORY THE MUNITIONS MADE BY AMERICAN INDUSTRY, LABOR AND MANAGEMENT PLAYED A VERY IMPORTANT ROLE. THERE IS GLORY FOR US ALL IN THIS ACHIEVEMENT. Signed, Eisenhower, General Commander and Chief, Allied forces in Africa
} 
operation of "about a quarter of the best of the mine crew." Forrester wrote: "We understand there is an arrangement between the Local Draft Boards and the State Director, that, if the quota from the local district cannot be filled without taking from the local district, the Local Board can call this fact to the attention of the State Director, who will or can, if possible, make up the deficiency from other districts while there is a surplus of men not eligible for deferment." In a later telegram, Forrester told Curzon to warn his men that if they quit, they would be subject to immediate induction. The miners were, no doubt, fully aware of their protected status. One man only stayed at Holden as long as he needed that protection - he quit the day after the war ended. (It should be noted that, while the workers were safe from induction, other members of the community were not. The son of D.A. Rodgers entered the service, was captured by the Japanese, and returned to a hero's welcome after he was liberated. A few years later, during the Korean War, the grocery store manager, Grant Birmingham, was drafted). ${ }^{83}$

Holden still had to reckon with the manpower shortage experienced by many American industries, especially during the later years of the war. According to a list Curzon sent to Sharp in August 1945, 216 employees voluntarily left Holden with the stated intention of enlisting in the military. (This was to keep track of men whom the company would be obligated to rehire under the G.I. Bill of Rights if those men wanted their jobs back, potentially a thorny issue when three or four men in succession quit the same position to enlist). There were increasingly limited options for making up for such losses as the war progressed. In late 1942, and again in 1943, Howe Sound secured

${ }^{83}$ J.J. Curzon to D.L. Forrester, 20 February 1945; D.L. Forrester to J.J. Curzon, February or March, 1945; Telegram, D.L. Forrester to J.J. Curzon, 20 March 1945; Bill Phillips and Linda Powell Jensen, interview with author; "Holden News," Chelan Valley Mirror, 19 October 1944; "The Holden Miner" newsletter, November 2007. 
furloughed soldiers as temporary workers, at least some of whom had worked as miners before enlisting. A government report stated that the soldiers were "proving very satisfactory workers," but there is little or no surviving feedback on their performance from a Howe Sound point of view. ${ }^{84}$ As with any new workers, the company probably had to contend with a rise in safety hazards stemming from their inexperience.

It is possible, but difficult to confirm from the existing evidence, that a small number of German prisoners-of-war with mining experience worked in or around the mine near the end of the war. A former resident suggested this in a 1983 interview, but the section of the company files that focuses on wartime manpower issues only contains correspondence between the War Production Board and H.H. Sharp that mentions the use of German POWs "for surface operations" as a possibility. This correspondence is dated January 1945, which leaves only a few months during which POWs may have plausibly worked at Holden.

It is probable, however, that the company employed ethnic minorities in increasing numbers during the war. The former resident mentioned above referred to the presence of Mexican workers in the mine, while the correspondence between Sharp and the War Production Board refers to "the importation of Mexicans for use in surface operations," adding "present indications are that their use in underground operations will be prohibited." 85 While, initially, Mexicans may only have been employed to work on the surface, it seems that at least a few worked underground. (A former miner who attended one of the reunions recalled a story about a Mexican worker who got into an

${ }^{84}$ H.H. Sharp to J.J. Curzon, 28 August 1945; Mitchel, "Report of Chelan Division,” July 1943; "Soldiers Work at Holden Mine," Wenatchee World, 21 August 1943.

${ }^{85}$ Joe Riggs, "Holden Mining Couple: Interviewer: Jean Swihart," 1983, Audio Archive; F.H. Hayes (Assistant Director of the Copper Division, War Production Board) to H.H. Sharp, 23 January 1945. 
altercation with his roommate, breaking the latter's guitar over his head. Apparently, the Mexican was not dismissed over this incident, and later worked as an underground machine operator). While the long-term community was overwhelmingly white (the 1940 census does not list a single self-identified non-white resident) and American- or Canadian-born, the foreign-born workers included metallurgist Victor Zanadvoroff, who left his native Russia during the Bolshevik Revolution and traveled to the United States via China. He eventually rose to become mill superintendent. ${ }^{86}$

The end of the war opened the door for other foreigners to enter the valley, not as workers but as visitors. These were representatives of overseas mining companies or foreign government agencies who came to observe American mining methods. In 1947, Holden received visits from a Chinese government geologist and a Norwegian mine superintendent. In 1950, it even hosted mining engineers from Japan. Reflecting on their visit in a letter to Sharp, Curzon wrote: "We believe that a strong Japan is a necessity for our own safety, but it does seem strange to be giving away our methods and systems to a nation who were our enemies just a few short years ago... Service men like George Bailey and Gil Plimpton who were fighting them in the air...must experience mixed feelings when they meet them in this country again." Curzon's belief in the importance of a strong Japan was undoubtedly influenced by the outbreak of the Korean War. The conflict generated manpower difficulties similar to those that prevailed during World War II. Another letter to Sharp reflects Curzon's concern about the possibility of the reservists among his employees, and especially the former officers on his staff, being

\footnotetext{
${ }^{86}$ J.J. Curzon to Archive MacGillivray, 2 December 1947.
} 
called to active duty, but the correspondence does not reveal whether the General Manager was able to secure protection for these men. ${ }^{87}$

\section{The End of the Mining Days}

The closure of the mine, which also meant the end of the Holden community as it had existed up to that point, did not come unexpectedly or without warning. In 1937, C.P. Browning was quoted as predicting that there were "30 years of ore ahead" for Holden. ${ }^{88}$ Although the operation produced concentrate for just under 20 years, not 30, the company and the residents knew all along that their community's length of existence was dictated by the ore supply and the profitability of extracting it. Two primary reasons have been given for the mine's closure. Firstly, it was getting more challenging technically to exploit the ore body, as those sections that were closest to the entry shaft had been exhausted by the late 1950s, requiring the ore to be lifted from deep within Copper Peak. The company did some exploratory drilling on Buckskin Mountain, the peak directly to the east of Copper, at the same level as the outcropping on the latter, but failed to find another deposit.

Secondly, the world price of copper was dropping, due in large part to competition from other low-grade mines in South America, where labor was cheaper. As Christine Plimpton noted in her thesis, the U.S. government bought half of the copper produced at Holden between World War II and the Korean War at 32 cents per pound. However, after the world price peaked at 46 cents in 1956, it dropped to 24 cents in 1957. Although the Holden operation may have been able to continue, it would have become

\footnotetext{
${ }^{87}$ R.D. Longyear to J.J. Curzon, 19 June 1947; H.H. Sharp to A. Okkenhaug, 17 September 1947; J.J. Curzon to H.H. Sharp, 22 July 1950; J.J. Curzon to H.H. Sharp, 12 August 1950.

88 “30 years of ore ahead at Holden," Wenatchee World, 5 November 1937.
} 
less and less profitable to do so. In fact, the Holden operation was never hugely

profitable to Howe Sound, due in part to the cost of transporting the concentrate all the way from the mine to the smelter in Tacoma. Holden's demise foreshadowed the eventual decline of the American copper industry over the next two decades. ${ }^{89}$

Among the residents of Holden Village, there is a persistent myth that the closing of the mine happened overnight, and that the miners were given a very brief period, a day even, to pack their belongings and vacate their homes. In fact, in April 1957, the management publicly announced that July 1 would be the last day of work, which gave the community two months' warning. There are stories about the surprising items left behind by the miners and found by the Lutherans a few years later, which gave rise to the myth. Some of these stories are true. Linda Powell Jensen believes that at least one family ate the last meal in their Winston home and left the dishes sitting on the table, and it is certainly true that Howe Sound left many things behind, including the giant coffee urns that now watch over the dining hall from the wall next to the dish-pit, and the black iron chairs scattered throughout the hall and other parts of the village. ${ }^{90}$

In any case, when the residents left, they had to make difficult decisions about how much of their homes they could take with them. While they could not sell the land or the houses as they were, they could salvage the material they used to build them. Private homes in Winston averaged $\$ 3,000$. At least two families completely dismantled

\footnotetext{
${ }^{89}$ Paasch interview, Audio Archive; Plimpton, 49-51; Bill Phillips, guided tour; Richard W. Etulain and Michael P. Malone, The American West: A Modern History, 1900 to the Present (Lincoln: University of Nebraska Press, 1989), 245-246. By the mid-1950s, the management knew that the operation probably had only a few years remaining. When the end finally came, J.J. Curzon was no longer around to see it. He was replaced as General Manager by Daniel "Jack" Roper in about 1954. According to Bill Phillips, Curzon wanted to be more open with the community about the approaching shutdown, but met with opposition from his superiors, and may have been replaced for this reason.

${ }^{90}$ Linda Powell Jensen, guided tour.
} 
their homes and shipped them downlake; the company paid for transportation as far as the dock in Chelan. Other families only took building components, such as windows and shingles. Those who left their homes behind were able to claim them as losses on their tax returns, thereby regaining some of their value. According to Linda Powell Jensen, one woman unsuccessfully tried to collect the insurance on her house by torching it. ${ }^{91}$

The dissolution of the community, at least of its physical framework and foundation, had a deep effect on the departing residents. Former resident Gary Bannister was of the opinion that Holden was not an "idyllic situation," but just a place where people came to work, and that "the mentality of the community was such that it never blossomed out to see what was here." This sentiment is refuted by nearly every other recorded recollection of what it was like to live at Holden during the mining days, and how hard it was to leave. Jack Frye called his time there the best ten years of his life. Pat Schonders recalls: "I had the best life ever up there, and all the kids did." Schonders' family remained at Holden somewhat longer than other residents because her father, a carpenter, was a member of the shutdown crew, which did such things as remove usable mill machinery and winterize the townsite. After the family finally left, Schonders and her father experienced deep homesickness, and visited the site the following year. Jack and Betty Frye did the same in 1960. According to Schonders, at least some former residents, including her father and Hal Field, hoped that another company would buy the

\footnotetext{
${ }^{91}$ Ibid.; "Now It's Closing Time At Holden," Wenatchee World, June 5, 1957; Bill Phillips, guided tour; Miles interview, Audio Archive.
} 
mine, allowing everyone to go back to work and home. ${ }^{92}$ Unfortunately, this was not to be.

${ }^{92}$ Gary Bannister, "Memories of School at Holden, 1941-1949," 1985, Audio Archive; Pat Schonders, interview with author, Chelan, Washington, 15 May 2011; Frye interview, Audio Archive. 


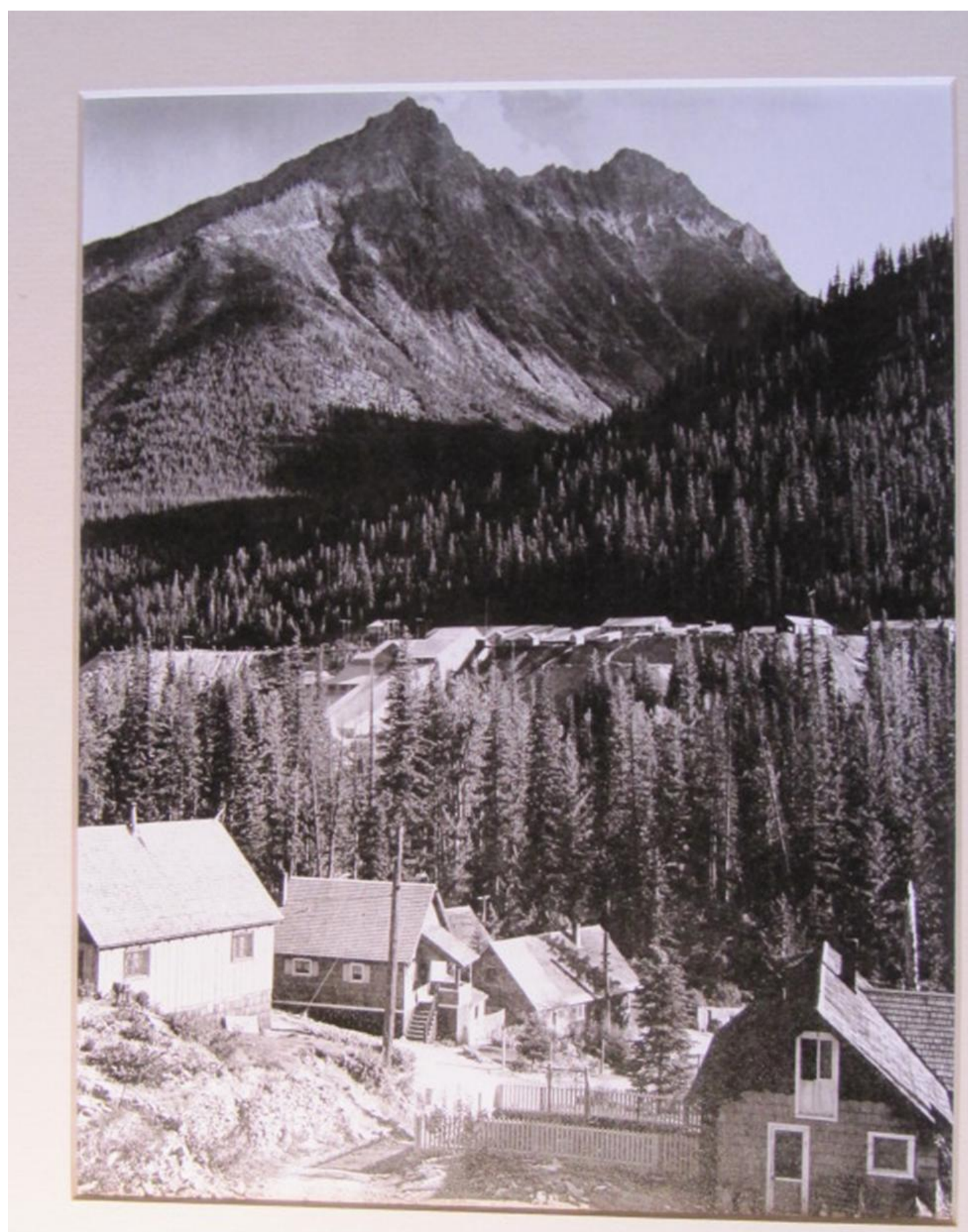

View of the mill and the buildings outside the mine portal from Winston Camp, date unknown. (Courtesy of Gene Starcher). 


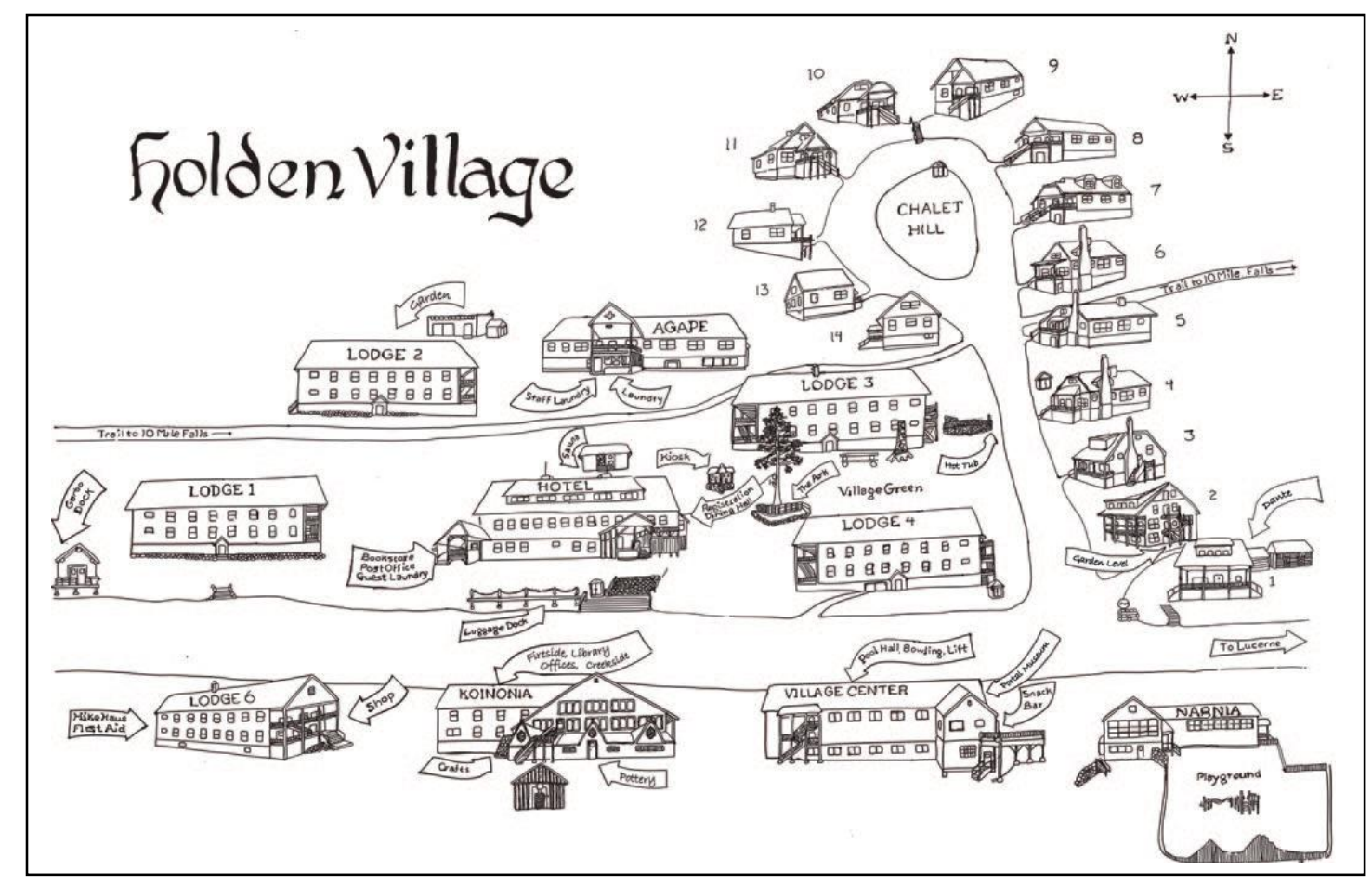

Holden Village guest map of the modern townsite. (From the Holden Village website) 


\section{CHAPTER TWO: EARLY HISTORY \& DEVELOPMENT OF HOLDEN VILLAGE}

The survival of Holden as something other than a mining town could be considered a lucky fluke. Certainly, the Lutherans have viewed it that way. If they had not acquired the townsite, it is quite possible that Holden would have disappeared entirely, the buildings dismantled or burned and the site reclaimed by the wilderness, as was the fate of Honeymoon Heights and Winston Camp. Instead, through a combination of good timing, persistence, vision, and hard work, Holden was reborn as Holden Village. As of this writing, it has existed as a retreat center for over 50 years. This chapter does not attempt to chronicle that entire period. Instead, it summarizes the first 20 years of the retreat center's history, during which time Holden Village evolved from a ghost town to a community not significantly different from today's; that is, a community with characteristics similar to those of the company town that preceded it.

I. The Interim Years, Wes Prieb, \& LBI's acquisition of Holden

Holden's ultimate fate was most in question during the first three years after the mine closed. The former residents' hopes that another company would buy the property must have faded quickly as salvaging operations moved in to dismantle the mill and other structures in the vicinity of the mine portal. Howe Sound apparently left a small crew to watch the buildings through the first year after the mine closed. After this crew departed, the company left Holden to the salvagers, hikers, Annie Folk's abandoned cats, and, of course, the native animals. The hikers were not kind to the buildings. When the first group of Lutherans arrived to begin restoring the townsite in 1961, they discovered hundreds of broken windows, as well as dormitory toilets that had been used for their 
intended purpose even though the water had not been running. Mice and rats took over the buildings, including the Hotel, where Howe Sound's kitchen workers had left behind a large quantity of boxed cereal. Fortunately, the townsite buildings withstood the weight of the winter snows. (The winter of 1957/58 was noted for being unusually mild. In March, there were only three to five feet of hard-packed snow on the ground) ${ }^{93}$

Numerous people saw possible uses for the property. It was in Howe Sound's interest to sell the buildings if it could, and it initially put them up for sale as a resort. As early as April 1957, the month the mine's closure was announced, outdoorsman and Holden resident Jim Sullivan attended a meeting in Chelan where he promoted the valley as one of the best skiing locations in the world. ${ }^{94}$ In 1959, a Seattle-based syndicate nearly bought Holden with the stated intention of transforming it into a high-class ski resort named "Shangri-La." However, this deal fell through only a couple of months after it was announced when the syndicate's plans to finance the envisioned resort came to nothing. The same year, the Wenatchee World reported plans to turn Holden into a "Father Flanagan-type Boys' Town," a place where as many as 1,000 "unloved and unwanted" boys between 12 and 18 years of age would be housed. This, too, did not pan out. Lastly, in late 1959, Northwest Christian College of Eugene, Oregon, communicated with Howe Sound about obtaining the property for use as a summer campus. This may have been the first time Howe Sound entertained the possibility of donating the property. The college did not pursue the idea very far, probably for the same financial reasons that

\footnotetext{
93 “How Is It With Holden by Now?" Wenatchee World, 6 March 1958; Paul Hinderlie \& Larry Howard, guided tour, 12 August 2010; Charles Lutz, Surprising Gift: The Story of Holden Village, Church Renewal Center (Chelan, WA: Holden Village Press, 1987), 39; Wilton Bergstrand, "Beginning: A Commentary by the Original Board Members," 1996, Audio Archive; Gil Berg \& Bill Phil, "Gil Berg \& Bill Phil Interview," 1985, Audio Archive.

${ }^{94}$ Wenatchee World, 5 June 1957; Lutz, 35.
} 
later led some members of the Lutheran Bible Institute feasibility committee to doubt whether they could accept Holden even as a gift. ${ }^{95}$

LBI's acquisition of the property was largely unplanned. In 1957, Wes Prieb, an Army Corps of Engineers purchasing agent and former intelligence courier from Webster, South Dakota, read an article in an Anchorage newspaper about the mine's closure, and immediately recognized Holden's potential as a church youth camp. He wrote to Howe Sound asking about the availability of the property. The company responded that it was up for sale for $\$ 100,000$. Sometime in the next year, Prieb moved to the Seattle area and enrolled at the Lutheran Bible Institute, a small college then located in Issaquah. (It has since relocated to an Everett campus). In 1958, he wrote a second letter to Howe Sound, in which he suggested that Holden might be useful to LBI. At this time the company still entertained prospects of selling the property, and gave Prieb the same reply as before. Finally, in 1960, Prieb wrote a third time, and this time received a telegram instructing him to call Howe Sound's office in Magnum, Utah. He did so, and was told that the company was prepared to donate the property to LBI, including both the townsite and the 225 acres' worth of mining claims on the south side of the creek. This went far beyond Prieb's own expectations - he had only dared to hope that the company might reduce the price tag on the property. ${ }^{96}$

\footnotetext{
${ }^{95}$ Wenatchee World, "Holden Boys' Town Project Announced," 5 May 1959; "Holden May Be Sold As 'Luxury Resort'," 13 May 1959; "Holden Purchased, Named Shangri-La," 15 May 1959; "Sale of Town of Holden Reportedly 'Falls Through'," 12 July 1959; "Holden May Be Campus for College," 22 November 1959. There are stories about more outlandish possible uses for Holden, including the suggestion that it be turned into a school for government spies. This scheme was later echoed by Carroll Hinderlie, who wrote to the government suggesting that it build a secret airfield in the valley, as he stated in a 1984 interview with Ellen Gamrath. How he expected it to remain a secret while sharing the valley with the retreat center is anyone's guess - but he may not have been entirely serious.

${ }^{96}$ Lola Deane, editor, Holden Village: 50 Years of Memories (Chelan, WA: Holden Village Press, 2012), 6. 
Prieb had done all this without informing the college authorities, who now had to decide what, if anything, they should do with the unexpected donation. In June 1960, a small LBI group visited Holden, including Prieb and college president E.V. Stime. They discovered that the buildings in the townsite were structurally sound, though all needed a good deal of cleaning and repair work. Following this visit, Seattle businessman and LBI board member Gil Berg chaired a feasibility committee to determine the next step. Berg was later quoted as saying: "One of the biggest things of my life has come into my hands and I don't know what to do with it." During this phase, the Forest Service, which still owned the land on which the buildings stood, tried to interest the Lutherans in also taking charge of the remaining houses in Winston. The Lutherans declined, partly because the houses had not withstood the accumulated snows of the last few winters as well as the townsite. This sealed Winston's fate; in fall 1962 (or spring 1963, according to Linda Jensen) the Forest Service bull-dozed and burned the remaining houses to eliminate them as a fire hazard. Today, concrete steps along the path to the ballfield indicate where front doors once stood. ${ }^{97}$

The LBI feasibility committee gave way to a permanent board, chaired by University of Washington law professor Luvern Rieke, which first met in May 1961. Gil Berg stayed on as the first executive director. The board set a goal of raising a quarter of a million dollars over the course of three years to finance the project. It also made some decisions concerning what kind of establishment Holden would be in the long run. From the beginning, Prieb and others had envisioned Holden as a camp for young adults.

\footnotetext{
${ }^{97}$ Gil Berg, "Holden History," 1979, Audio Archive; Linda Jensen, guided tour; Merton Strommen, "Holden History: Reflections on the Beginnings," 1985, Audio Archive. Some of the Winston foundations were destroyed in the late 1980 s to make room for the installation of a village drainfield.
} 
Accordingly, in late 1960, the board brought the youth directors of the American

Lutheran Church, the Augustana Lutheran Church, and the Lutheran Free Church into the discussion. One of these men was Rev. Wilton Bergstrand. ${ }^{98}$

Bergstrand had been the youth director of the Augustana Lutheran Church since 1938. He was an influential figure in the church's youth-oriented and youth-run Luther League, known for his fundraising skills. In The Augustana Story: Shaping Lutheran Identity in North America, Maria Erling and Mark Granquist summarize his achievements: "What Bergstrand accomplished in his career in youth work was to enlist support from almost every conceivable faction of the synod, from social justice-minded progressives to fervent Bible pietists." However, the Lutheran church as Bergstrand and his colleagues knew it was undergoing major change during this period. In 1960, the Augustana Lutheran Church was two years away from a merger with three other Lutheran synods, which resulted in the Lutheran Church in America (LCA), itself a forerunner of the existing Evangelical Lutheran Church in America (ELCA). The United Lutheran Church in America (ULCA), the largest partner in the merger, had 2.4 million members as opposed to the Augustana Church's 600,000. The ULCA evidently put less emphasis on youth work as activity apart from the work of the church in general, and, as

\footnotetext{
98 "Holden Village national in scope," Chelan Valley Mirror, 26 January 1961; "Church Finds Holden 'Exciting Frontier'," Wenatchee World, 7 December 1960; Luvern Rieke and Bill Dierks, "Holden History: Dr. Luvern Rieke Conversation," 6 August 1984, Audio Archive; Elmer Witt, "Holden," 1987, Audio Archive. The Holden board's composition has changed somewhat over the years. In 1963, there were 15 voting seats, which were divided evenly between representatives appointed by the youth boards of the American Lutheran Church (ALC), the Lutheran Church-Missouri Synod (LCMS), and the Lutheran Church in America (LCA). In 1987, the ALC, LCA, American Evangelical Lutheran Church (AELC), and LCMS all had representatives on the board, but there was also one representative from the Lutheran Church of Canada and two Methodists. In 1988, The ALC, LCA, and AELC united to form the Evangelical Lutheran Church in America.
} 
a result, many congregations within the LCA questioned the importance of preserving a youth organization, such as the Luther League, in a sort of auxiliary role.

Within ten years of the merger, the Luther League disbanded. Bergstrand may not have foreseen this outcome, but he probably saw in Holden a place where the Augustana church's strong tradition of youth work could be preserved. Another founding member of the ELCA, the American Lutheran Church (ALC), emerged from a three-way merger in April 1960. Its youth department also became involved in the Holden project, as did that of the Lutheran Church - Missouri Synod (LCMS), whose Walther League was similar to the Luther League in structure and purpose. ${ }^{99}$ Early promotional material reflected the planned youth focus. An undated pamphlet preserved in the Holden Portal Museum, probably dating back to 1961-62, reads: "Holden Village, set in the grandeur and seclusion of the Northern Cascades in Washington is being developed by the Lutheran Church as an experimental village for youth work and as an international retreat center for young adults." Berg laid out a program that included spiritual training for young pastors and youth workers. However, the program also included "providing a community experience for families which will help them enter into potential Christian family living" and "providing facilities for other Christian groups who are willing to enter into the spirit and discipline of the village." The board did not intend Holden to be a Bible camp set aside exclusively for youth, despite the heavy emphasis on youth

\footnotetext{
${ }^{99}$ Maria Erling \& Mark Granquist, The Augustana Story: Shaping Lutheran Identity in North America (Minneapolis: Augsburg Fortress, 2008), 280-281, 332-343; E. Theodore Bachmann, The United Lutheran Church in America, 1918-1962 (Minneapolis: Fortress Press, 1997), 306; Clifford E Nelson, Lutheranism in North America, 1914-1970 (Minneapolis: Augsburg Publishing House, 1972), 233. In 1961, the Luther League Executive Committee voted to donate its library to Holden Village.
} 
ministry. ${ }^{100}$ The board quickly reached another important decision: Holden was not to have a direct relationship with any particular Lutheran synod or school. Luvern Rieke described the board as wanting the village to maintain a connection to the church while remaining separate from the church as an organization. Partly for this reason, Holden became incorporated as a non-profit entity, Holden Village, Inc., on February 1, $1961 .^{101}$

Wes Prieb was not deeply involved in the board's deliberations during this period, but his close relationship with Holden Village continued for the rest of his life. He spent part of the fall of 1960 living alone in the village as the first of several caretakers. After returning for parts of the winters of 1962-63, 1965-66, 1967-68, and 1968-69, he became the summer pool hall director ("PhD") in 1969, a position he occupied every year until his death in 2000 . He remains one of the community's most celebrated residents. ${ }^{102}$

II. The first work groups, leaders, and summer programming

One of the Lutherans' first tasks was to clean up the townsite. The composition of the first work group reflected the emphasis on Holden Village as a haven for youth. In the summer of 1961, Bergstrand led a group of 41 high-school to college-age volunteers from around the country (though most came from the upper Midwest) and a few other adult leaders to begin the cleanup effort. This group became known as the Forerunners. In addition to replacing hundreds of broken windows and dealing with a variety of messes in numerous buildings (including four inches of impacted grease in the Hotel

\footnotetext{
100 "Holden Village," pamphlet, Portal Museum; "Holden to Become 'Swiss Village'," Wenatchee World, 9 December 1960.

${ }^{101}$ Rieke and Dierks, "Holden History"; "Lutherans Developing Retreat in Cascades: Given Ghost Town in Alpine Setting," Tacoma Sunday Ledger-News Tribune, 6 August 1961.

${ }^{102}$ Deane, 8-10; Wes Prieb, "Reminiscences of Holden," 1984, Audio Archive.
} 
stoves), the Forerunners discovered a number of interesting things left by the miners, including the long-defunct slot machines, which they removed. ${ }^{103}$

Holden Village was more like a true camp than a retreat center during the first few years, primarily because the village lacked many of the resources that the present community can safely take for granted. For example, before 1964, the staff slept in sleeping bags, rather than sheets, and staff members occasionally had to sleep outdoors to make room for guests. The village's first vehicle, a 1961 International flatbed truck, served as the only transport for both luggage and people before the village put two donated buses into service in 1962. Despite these limitations, the project made steady progress. A second work group went up in June 1962, and the village hosted some 1,600 guests that summer (some of whom visited the village either going to or coming back from the World's Fair in Seattle). By 1963, Holden was hosting 2,500 guests per year, which remained the average through $1968 .^{104}$

The development of summer programming over the next few years makes it clear that Holden Village's leaders were still uncertain about the project's direction. Some long-term elements of village life were established as early as 1961, such as daily Bible study. However, some programmed activities were never repeated after the 1960s. From 1963 to 1965, Holden hosted an annual retreat for Air Force personnel during the month of August, organized and led by Air Force chaplains. According to Werner Janssen, this tradition ended because the Air Force was concerned about not being able to speedily evacuate anyone for medical reasons, so much so that it staged a medical crew at 25-mile

\footnotetext{
${ }^{103}$ Rieke interview, Audio Archive; Wilton E. Bergstand, "Holden Village," Portal Museum document; Berg and Phil interview, Audio Archive.

${ }^{104}$ Lutz, 54-56; Phyllis Anderson, Darryl Lundby, and Bill Dierks, "Early Programming," 1991, Audio Archive.
} 
Creek (just north of the present-day ferry landing at Field's Point on the west shore of the lake) through every week of the retreat. Another group that came up for a number of summers during the 1960s was the evangelical Christian organization Camp Farthest Out. One year, its Holden program featured evangelist Jean Carter Stapleton, Jimmy Carter's sister. By the early 1970s, however, Holden Village had become more independent with regard to summer programming, and its management was no longer willing to yield a week of its schedule to an outside organization. ${ }^{105}$

The development of summer programming went hand in hand with the evolution of Holden's leadership. Gil Berg remained the executive director and on-site manager through 1963. During the off-season, when there was no one in the village aside from one or two caretakers, the Holden office was located on the second floor of his Ballard neighborhood fuel oil business. When Berg decided not to continue as director, the board offered the directorship to Wilton Bergstrand, who had also occupied a leadership role up to that point. However, when he hesitated to accept, the board instead gave the position to Rev. Carroll Hinderlie. ${ }^{106}$

Hinderlie became the most dominant personality in the village's early history. A "dyed-in-the-wool Norwegian Lutheran" (in the words of Werner Janssen), he was a man of broad education, well-versed in church history and the theological perspectives of churches other than his own. He and his wife, Mary, had already accumulated extensive experience as community leaders in a variety of settings prior to their arrival at Holden in

\footnotetext{
${ }^{105}$ Lutz, 55; Carroll \& Mary Hinderlie, "Holden History: A Conversation with Carroll \& Mary Hinderlie by Ellen Gamrath," 6 June 1984, Audio Archive; Werner Janssen, email correspondence with author, 30 November 2012. The board once discussed hosting a Boeing conference at Holden, but decided against it. If they had decided to do so, the conference probably would have remained a one-time experiment, but it does invite one to speculate about Holden's odds of having become a conference center.

${ }^{106}$ Lutz, 89; Werner Janssen, email correspondence with author, 30 November 2012.
} 
1963, most notably in a Japanese internment camp in the Philippines during 1941-1945. The Hinderlies barely survived this ordeal; Carroll, who was a large man, lost nearly half his weight before he was liberated. After the war, Hinderlie served a number of parishes in the upper Midwest before becoming youth director for the Evangelical Lutheran Church. Prior to accepting the Holden Village directorship, he taught at Luther Seminary in St. Paul. He ultimately held the directorship for 13 years. Though he and Mary only lived at Holden during the summer months, they raised funds and recruited summer faculty members during the off-season. ${ }^{107}$

Hinderlie had a major impact on the face of worship at Holden. Although he insisted that every guest and staff member attend daily Vespers and Eucharist services, he did not want Holden Village to assume the aspect of a monastic community. Services were to be short; he considered Vespers services longer than 20 minutes to be boring, and boredom, he believed, was "of the Devil." Morning Matins observances and Bible studies became optional for staff and guests. Among Hinderlie's mild eccentricities was a fondness for leading Bible studies in the village sauna, located outside the dining hall; this was in the spirit of "holy hilarity" that has characterized Holden Village's approach to worship, and much of community life in general, to this day.

Most importantly, perhaps, Hinderlie effectively united the village population as one worship community. In the early days, members of the conservative Missouri Synod branch of the Lutheran church did not necessarily take communion with the other Lutherans in the village, who mostly represented the ALC and LCA. At some point during the late 1960s or early 1970s, however, Hinderlie and the Missouri Synod

${ }^{107}$ Deane, 24-31. 
Lutherans present at Holden came to an agreement: there would be one weekly Eucharist service for the entire community. In 1971, Holden Village gained recognition as a congregation within the ALC (the synod to which Hinderlie belonged as a rostered pastor) upon the formation of Fullness of God Lutheran Church. Up to that point, Eucharist services at Holden had been treated as an extension of services at Lake Chelan Lutheran Church for church record-keeping purposes. At least today, most members of the long-term community choose not to formally join Fullness of God Lutheran Church, but it was founded partly to give full-time Village employees the opportunity to be participating members of an official congregation. ${ }^{108}$

Werner Janssen was another figure who became an integral part of the Holden community during the early years. The board hired the 24-year-old Boeing engineer as Holden Village's first Business Manager (sometimes listed as General Manager) in November 1963. From 1966 to 1984, he lived at Holden year-round, thereby becoming its most continuous resident during the Village era, and probably during any period. In 1966, he and his first wife became the first couple to marry at Holden since the mining years. While the Hinderlies provided the village with spiritual direction during the summer months, Janssen assumed responsibility for the day-to-day operation of the village throughout the year, thereby establishing a constant managerial presence. He also acted as Holden's chief representative to its landlord, the Forest Service, which still owned the land on which the townsite was built. ${ }^{109}$

\footnotetext{
${ }^{108}$ Paul Hinderlie, interview with author, 26 August 2010; Werner Janssen, telephone interview with author, 24 July 2012; Werner Janssen, "Holden Village: What Would You Like to Know?" 1993, Audio Archive; Werner Janssen, email correspondence with author, 30 November 2012.

${ }^{109}$ Deane, 36; Janssen interview; Janssen, "Holden Village: What Would You Like to Know?"
} 
Several other individuals played important roles in shaping the community. They included Augustana College professors Rudy Edmund and Beanie Lundholm, both of whom were recruited by Wilton Bergstrand as two of the first volunteer summer faculty members. Edmund, a geologist, became the first curator of Holden's Portal Museum. Lundholm became Holden's summer musician-in-residence. (For many years, the community had "Beanie Sings" following every dinner). Edmund's wife, Doris, started the children's program, later called Narnia. Lundholm's wife, Gertrude, made major contributions to the foundation of Holden's crafts program, including the purchase of Holden's first loom. The crafts program was first centered in the basement of Chalet 7, where the Lundholms and their three children lived whenever they were in the village. Gertrude Lundholm started the tradition of serving coffee in her chalet on Sunday mornings, a practice that various long-term staff members have continued in several different chalets up to the present.

Other recurring faculty members included geologist Larry Collins and his wife, biologist Barbara Collins. In 1970, the teaching staff included professors of theology, English literature, drama, art, and astronomy from a number of Lutheran and nonLutheran schools, including Pacific Lutheran University, Golden Valley College, California Lutheran University, and St. Olaf College; there was also a yoga instructor and a ceramics artist. The impact of individual summer faculty members probably declined slightly after the director (either Carroll Hinderlie or his eventual successor, John 
Schramm) decided that no one would be invited to come up for more than two years in a row; this was to ensure that the summer program would not grow repetitive. ${ }^{110}$

\section{The Evolution of the Year-Round Community}

The first winter residents were caretakers, among whom Rueben Thompson is remembered most often. Thompson spent the winters of 1961 and 1962 in the village with no one but his dog for company. Aside from day-long journeys to and from Lucerne to pick up mail and supplies, his isolation was total. In 1964, Thompson (who unfortunately was a binge alcoholic) was joined by his nephew and one other. In 196566, the number of winter residents increased to seven (including Wes Prieb), but all except one left during the course of the winter. The holdout was 21-year-old Terry Sateren. In 1966-67, during which winter Werner Janssen began his long residency, Holden Village bought a Swedish SnowTrac, its first snow vehicle. This made it slightly more practical for more than a handful of people to live in the village during the winter months, but the off-season population remained limited to Werner and Judy Janssen, mechanic Joel Wallmer, Wallmer's wife, Ruth; Sateren, and Sateren's Samoyed. Winter conditions persist well into the spring at Holden's elevation in the Cascades; the group was not relieved until May 1967, as had been the case for Sateren the year before. ${ }^{111}$

The year 1968 marked a turning point in the development of the winter community. About 20 staff members and 30 guests celebrated Christmas in the village.

Although Holden still lacked the equipment to keep the road all the way open throughout

\footnotetext{
${ }^{110}$ Lutz, 46; Deane, 65; Paul Hinderlie interview; Lundholm, “A Conversation with Getrude Lundholm”; List of Teaching Staff from 1970, Portal Museum; Werner Janssen, email correspondence with author, 30 November 2012.

111 Terry Sateren and Bill Dierks, "Interview with Terry Saateran (sic): by Bill Dierks, Archivist," 1990, Audio Archive; Hinderlie interview; Werner Janssen, "Holden History: Since 1960," 1982, Audio Archive; "Visiting Holden Village, Where Winter Lingers," Seattle Times, May 7, 1967.
} 
the snowy months, the staff typically brought people in by bussing them up the switchbacks above Lucerne and then transferring them to a sled pulled by the SnowTrac for the rest of the journey. According to Janssen, in 1969, Holden had a winter population of $75-80$, roughly the same as today's average. The next few years featured similar numbers. ${ }^{112}$ Another important development was the remodeling of Dorm 5, which Howe Sound had left partly dismantled for unknown reasons. The summer of 1963 was cold and wet, which highlighted the lack of hot water in all the buildings except the Hotel and the need for a warm gathering space. The remodeling took place between 1964 and 1966. The result was the existing Koinonia building, which became the main center for worship activities during the winter. (It has been re-remodeled since then, and now also houses the library, the crafts center, and administrative offices). ${ }^{113}$

The establishment of the winter community paved the way for the introduction of the Holden group home in 1970. In turn, this led to the reestablishment of the Holden school. The group home might be viewed as a miniature version of the boys' town that had once been envisioned as a possible use for the abandoned townsite. In both cases, the goal was to "straighten out" directionless youths by placing them in a supportive wilderness community. The group home represented a collaboration between Holden Village and the state of Washington, which required the village to support an accredited public school for the boys. The state paid the village based on the number of boys in residence, but Holden Village ultimately covered some expenses. Each year, up to six high-school age boys came by court referral from throughout Washington to attend the

\footnotetext{
112 Karen Strom, “The Years: 1966-1980,” 1986, Audio Archive; Mark Bjerke, “An Evening of Holden History," 1990, Audio Archive; Gene Starcher, interview with author, 27 March 2012; Janssen interview; "Sixty to spend Noel at Holden," Wenatchee World, 26 November 1970; "Werner Jensson (sic) spoke on Holden Village at Chamber meeting," Chelan Valley Mirror, 19 December 1973.

${ }^{113}$ Werner Janssen, "Holden - Part 1: Past, Present, \& Future,” 1984, Audio Archive
} 
program. A few returned for second or third years. The boys lived in Dorm 6 with their administrator/teacher, who reported to a social services superior in Wenatchee once a month. Between 1972 and 1975, later executive director Tom Ahlstrom filled this role. Ahlstrom taught a number of subjects, but "every class came down to remedial English." Despite this, about half of the boys graduated from the Holden school. There were at least a few incidents of theft, but few, if any, of the boys were expelled from the community for stealing. The group home came to an end in 1979 when a new state standard required it to have a on-site child psychologist, which Holden could not afford to support. ${ }^{114}$ However, the Holden school itself survived, as its other attendees included the children of staff members.

At least one other educational program was made possible by the establishment of the year-round community. This was the Christian Lifestyle Enrichment Program, which began in the early 1970s and continued until 1978. It was headed by another Holden teacher, John Graber, the Hinderlies' son-in-law. Lifestyle Enrichment was a nine-month alternative education program designed for young adults, especially recent high school graduates. Each year involved 6-20 participants. Among the program's stated points of focus were prayer, Gospel study, and "living in community." While reading and discussing texts by C.S. Lewis, Thornton Wilder, Fyodor Dostoevsky, T.S. Eliot, Soren

\footnotetext{
${ }^{114}$ Tom Ahlstrom, telephone interview with author, 29 August 2012; Werner Janssen, "Interview of Werner Janssen by Chuck Lutz," 1987, Audio Archive; Hinderlie interview. One boy who stole about $\$ 200$ worth of cigarettes from the Holden store over the course of his stay came back as a volunteer over 30 years later and paid his debt. In his assessment of the program, Werner Janssen said: "I came to the conclusion...that the greatest thing that we offered these boys was a year or nine months away from harassment by the legal system....also it gave them an opportunity to see a lifestyle of caring for each other, family life....an option they'd never been exposed to before."
} 
Kierkegaard, Charles Williams, Dietrich Bonhoeffer, Martin Luther, and others, the participants also worked as part-time village volunteers. ${ }^{115}$

Although the Holden school remains (it is discussed in the third chapter), no similar programs emerged to succeed the group home or Lifestyle Enrichment. The winter community came to consist almost solely of staff members and their families. To this day, only a handful of guests visit the village between October and May, except during the Thanksgiving break and the two weeks preceding and following Christmas.

\section{Evolution of work at Holden Village}

As the nature of the year-round community experienced gradual change during the first two decades, so did the work of the residents, and the way in which those residents were compensated for their work. A retreat center staffed only by volunteers and a couple of paid managers eventually gave way to one that included a few workers with stipends and a few more managerial positions. However, Holden Village remained reliant on the expertise of skilled short-term volunteers, including many retirees. Without such people, the village would have had difficulty completing numerous projects critical to its operation. As a non-profit organization, it also remained heavily dependent on donations and other kinds of financial assistance to fund those projects.

In the earliest years, the youth offices of the three major Lutheran synods (LCMS, LCA, ALC) were responsible for summer staffing, reflecting the initial conception of Holden Village as a place primarily focused on youth ministry. Each synod recruited the entire volunteer staff for one summer month. However, this scheme did not work out, presumably because the rapid turnover did not make for a smooth operation. In 1965, the

\footnotetext{
${ }^{115}$ John Graber (?), “A General Statement of the Christian Life Enrichment Program”; Lutz, 75.
} 
management decided to begin recruiting volunteers directly out of the Holden office, which communicated with applicants partly through a secretary in Chelan. Werner Janssen was in charge of staffing; usually, there were so many applicants that summer staff members were not allowed to come back two years in a row. There were very few or no stipends for volunteers in the early days. In 1961-62, the only two people on the payroll were the cook and the caretaker. In 1964, the Wenatchee World reported that of 50 staff members, only five were paid. ${ }^{116}$

Most of the village work areas in existence today developed during the first two decades, although, for the most part, they were less structured than they later became. The kitchen, for example, originally employed only one paid individual. The village diet varied somewhat depending on who was the head cook at the time, although it was meat and potato-based throughout the 1960s. Paul Hinderlie (Carroll's son) became head cook in 1972. When he took over, Holden's diet began to feature less meat, more vegetables, and more homemade bread. This shift was mainly the result of economic factors, as the early 1970 s witnessed a rise in the price of meat. ${ }^{117}$ Today, the village diet is generally similar to what it was then, but the kitchen workers now include several paid cooks, at times including one or two "kitchen coordinators" who are more experienced and have a few managerial responsibilities.

The most important changes took place in the structure of Holden's management and staffing department. In 1977, the board decided that a change in leadership was needed and removed Carroll Hinderlie from the directorship. His departure marked the

\footnotetext{
116 "Church Revives Holden Village,” Wenatchee World, 21 August 1964; Janssen, "Interview of Werner Janssen by Chuck Lutz"; Gil Berg, Wes Prieb, Omar Klein, "Holden Old-Timers Tell All,” 1983, Audio Archive; Deane, 38.

${ }^{117}$ Bob Hewitt, interview with author, Holden Village, 23 April 2011; Deane, 73; Janssen interview.
} 
end of an era at Holden. Hinderlie's close friend and immediate successor, Fritz Norstad, later said: "As happens with most new enterprises, the Village had become something like an inverted triangle, resting on the point which was its prime shaper, Carroll Hinderlie. There is intense anxiety when that point is removed." ${ }^{118}$ Holden Village survived the transition, but underwent significant change over the next few years. Beginning with Norstad and his wife, Gertrude, the executive director and his/her family became year-round residents. During the Hinderlies' long tenure, the couple had assumed responsibility for programming and worship, while Werner Janssen had taken charge of village business and operational concerns, including staffing. The role of village pastor remained linked to the directorship during Norstad's interim year, and during the first year of his permanent successor, John Schramm. However, Holden Village then called Nancy Winder to become its first full-time pastor. Ever since that time, the executive director and the village pastor have remained separate positions. While Janssen remained Business Manager until 1983, volunteer recruitment became the responsibility of the new Staff Coordinator position. Finally, the Schramms took the important step of negotiating stipends with staff members who could not stay for a full year or more purely as volunteers. This enabled more people to commit to the 1-2 years that now constitute a typical "long-term" stint on staff. ${ }^{119}$

Another factor that allowed more people to serve on long-term staff was the ending of the Vietnam War. With the exception of conscientious objectors, of whom at least one was assigned to do two years of alternate service at Holden in 1970-72, the

\footnotetext{
${ }^{118}$ Lutz, 63-64.

${ }^{119}$ Deane, 40, 61; John \& Mary Schramm and Charles Lutz, "Schramm Years: 1978-1984," 1986, Audio Archive.
} 
Vietnam War generally discouraged young men from volunteering on staff for longer periods, as they could not avoid the draft by staying at Holden. Janssen recalls that the village community was strongly against the war. At least a few residents shunned a veteran staff member who returned after serving in the military. However, the war "didn't occupy the village time to a great extent." Like most problems belonging to the world beyond the valley, and without television to provide the residents with a steady stream of news, Vietnam must have seemed impossibly far away. ${ }^{120}$

Despite these changes, Holden's dependence on multi-skilled volunteers remained constant. Among the early volunteers were a number of invaluable jacks-of-all trades. One was Hortie Christman, a retired barber from Chelan, whom Carroll Hinderlie dubbed "the patron saint of Holden volunteers." In contrast to the pastors, engineers, and other college graduates who formed the core of Holden's leadership, Christman came from a logging background and had only an eighth-grade education. However, he had sufficient engineering talent to guide excavations and bridge-building projects. Terry Sateren, who spent nearly every summer of his 20 s at Holden, served as a carpenter, electrician, piano tuner, artist, and occasional cook. He lent his skill to building the existing jacuzzi and the original creekside sauna. ${ }^{121}$ Today, though it regularly employs many talented people on long-term staff, the village still relies on skilled short-term volunteers to assist with and sometimes direct important projects.

\footnotetext{
120 "Cascades Retreat Unbends Lives," Tacoma News-Tribune, 30 January 1972; Janssen interview.

${ }^{121}$ Janssen interview; Terry Sateren, "Interview with Terry Saateran (sic): by Bill Dierks, archivist," 1990, Audio Archive. Sateren first came to Holden in 1963 as a member of a drama troop; one of his companions was the Hinderlies' daughter, Maren. After leaving the village, he worked for the Guthrie Theatre in Minneapolis and the Minnesota Opera Company, where one of his coworkers was later summer faculty member Phil Brunelle, known for his musical contributions to Garrison Keillor's famous radio show, The Prairie Home Companion.
} 
Another major reason why Holden was able to survive and develop throughout the 1960s and 1970s, and indeed to the present day, was the financial assistance of guests and other supporters within the broader Lutheran church community, including some who made donations without ever having seen the village. At its inception, Holden Village, Inc., had no collateral to offer potential creditors; its only debt was to Gil Berg, who issued a loan for the purchase of 1961 International truck used by the Forerunners. During the first four years the three Lutheran youth departments contributed a total of $\$ 15,000$ per year toward operational expenses. Thanks to the fundraising skills of Wilton Bergstrand, 375 businessmen who supported the ALC's Luther League pledged to donate at least $\$ 100$ per year to Holden Village. These contributions were vital to getting the Holden project off the ground. Carroll Hinderlie and Werner Janssen also did extensive fundraising in the early years, when promotion of the village was mostly by word of mouth, and to a lesser extent by articles published in church magazines and newspapers. Janssen estimates that guest registrations made up 60-70 percent of the village revenue during his years as Business Manager, while donations made up the remainder. ${ }^{122}$

Without specific donations, many physical features of the community that endured long enough to be taken for granted, including some still in existence, would not have materialized, or they would have fallen into disrepair. At one point, Holden Village needed $\$ 1,200$ to pay for the installation of a steel hood above the open-hearth fireplace in the middle of the Fireside Room, Koinonia's main gathering space. After an electrician who was helping with the Koinonia remodel donated \$100 toward purchasing the hood, Werner Janssen made a public appeal during a meal in the dining hall, asking

\footnotetext{
${ }^{122}$ Deane, 37; Bergstrand, "Beginning: A Commentary by the Original Board Members," Audio Archive; Werner Janssen, email correspondence with author, 10 December 2012.
} 
11 other people to match the electrician's gift. He quickly came up with more than double the needed sum. On a similar occasion, the community raised $\$ 5,000$ to purchase a saw mill. Much larger sums, such as $\$ 36,000$ needed to repair the hydro dam turbines in 1972 (discussed in the next chapter), were raised partly through fundraisers at regional Lutheran churches. Donations came in other forms, too. During the late 1970s, farmers and orchardists belonging to Gidion Lutheran Church in Connel, Washington, gave wheat, potatoes, carrots, cherries, and apples to the Holden kitchen. At this time, the kitchen was grinding its own flour and baking its own bread, which made the wheat donations especially welcome. In the summer of 1976, Holden Village honored a man who had created a foundation supporting it that had generated between $\$ 2,000$ and $\$ 2,500$ per year since 1962 , and a young woman who had given her inheritance for the purchase of a village boat. That same summer, Holden Village celebrated its $50,000^{\text {th }}$ guest. $^{123}$

Holden Village's success can be measured by the simple fact of its continuing existence as a retreat center, which it owes to the generosity of donors, the patronage of hundreds of thousands of guests, the hard work of countless volunteers, the enthusiasm of summer faculty members, the cooperation of the Forest Service, the vision and direction of Gil Berg, Wilton Bergstrand, Werner Janssen, Carroll and Mary Hinderlie, and other leaders; and the initiative of Wes Prieb. If any of those elements had been factored out, the experiment would have failed, and Holden would have met a different fate.

${ }^{123}$ Erwin Weber, "My Days at Holden," An Illustrated Book of Holden Village, the Lutheran Retreat High in the Cascade Mountains Near Lake Chelan, Washington (Unpublished, 1977), 37-38; Wenatchee World, "Holden asks help for \$36,000 repair," 3 November 1972, "Mural dedication, holiday celebration," 30 July 1976; Janssen, "Holden - Part 1," Audio Archive. 


\section{CHAPTER THREE: ANALYSIS OF THE PARALLELS (AND SOME DIFFERENCES) BETWEEN THE TWO COMMUNITIES}

Today, daily life at Holden Village follows predictable patterns, most of which were established during the 1960s and 1970s. A bell suspended from a tree outside the east entrance of the dining hall calls the residents to meals, bus arrivals and departures, and evening worship services. It is also used to announce the beginning of other activities open to the whole community, such as games, lectures, and film viewings. ${ }^{124}$ Most residents take all or nearly all their meals in the dining hall, though they are free to eat in the chalets or dormitories where they are housed. They are expected to be present for bus arrivals and departures so they can greet and say goodbye to guests and staff members, both of whom are very transitory populations, especially between May and September. All staff members commit to doing certain community chores on a weekly or monthly basis, among them washing dishes after each meal in the dining hall and sorting the village garbage into containers for items to be burned, recycled, or sent to a downlake landfill. ${ }^{125}$ All staff members are required to be present for Vespers services, which generally take place about an hour and a half after the evening meal concludes. In keeping with Carroll Hinderlie's vision, these are short services, 20-30 minutes long, and typically consist of a brief sermon or personal history, the singing of hymns, meditation, or group prayer. Eucharist services, held on Sunday evenings, more closely resemble

\footnotetext{
${ }^{124}$ According to Wes Prieb, this bell once crowned a steam locomotive, and was donated to Holden by a former employee of the Great Northern Railroad.

${ }^{125}$ There is a story about an English bishop with two PhDs who came to the village as a summer faculty member. The bishop considered "dish team" beneath his dignity, but Hinderlie said that no one was exempt from community chores, and insisted that he take part in it. This story may be myth; Werner Janssen believes that faculty was not required to wash dishes until John Schramm became director.
} 
traditional Lutheran church services. During the summer, worship is held in the rec hall, while it is held in Koinonia's Fireside Room throughout the rest of the year.

The staff still consists predominantly of young people, generally middle-class Lutherans who are either between college semesters or recent graduates. Many come from families that have been associated with Holden for decades. Residents who stay for a year or more as work area supervisors are considered "long-term," which entitles them to live in one of the chalets, a monthly stipend of about $\$ 500$, health insurance, limited reimbursement for travel expenses to and from Chelan, generous vacation time, and a certain number of "guest days," which allow them to invite friends or family members to stay in the village for free during the off-season. Long-term staff members include five to six lead cooks, three to four utilities team members, two staff coordinators, a bookkeeper, a publications coordinator, an administrative assistant, a contributions recorder, one or two information technology specialists, a crafts coordinator, a potter, a resident artist, one or two carpenters, a fire chief, a medic (usually a Registered Nurse), a laundry person, a mechanic's apprentice, a head housekeeper, a labor crew leader (the head "maverick"), a waste management supervisor (the "garbologist"), a worship assistant, a registrar, a postmaster, a bookstore coordinator, the village pastor, the managers, and the directors. The managers currently include a Business Manager, a Public Works Manager, an Operations Manager, and a Hospitality Manager. As of this writing, there are two directors, a married couple who previously occupied the positions of Operations Manager and bookstore coordinator, respectively. The managers and directors, most of whom stay for more than two years and have families to support and permanent residences on the outside to maintain, are entitled to larger stipends. The 
mechanic is a salaried employee, and the two school teachers and a teacher's aide are paid by the Chelan school district.

Those who stay for less than a year are considered "short-term" staff members. They are divided between summer "area heads," who receive stipends, and true volunteers. Area heads include such seasonal positions as trails coordinator, barista, head gardener, Hike Haus supervisor, Narnia (children's program) supervisor, Junior Miners (youth program) supervisor, and snack bar supervisor. These staff members typically live in the chalets. True volunteers, who stay from a few weeks to a few months, typically work as laborers, cooks, housekeepers, trails workers, gardeners, or Narnia workers. Their numbers also include many skilled workers and specialists who come to work on such projects as updating the village fire suppression and detection systems. Volunteers typically live in Dorms 1 and 6.

As the number of paid positions has increased, so have the resources available to the village. The village fleet, which originally consisted of a lone 1961 International flatbed truck, now includes eight buses, three bombardiers (tread vehicles) for winter transportation, several vans and pickup trucks, and a wide variety of large trucks and heavy equipment. Each year, several long-term staff members volunteer to be on a professionally-trained fire brigade, which is outfitted with professional-grade protective gear and breathing equipment. All other staff members are trained to support the brigade in one capacity or another when the fire alarm goes off. There is also a professionallytrained team of first responders (though most do not have the full Wilderness First Responder certification) who support the medic and search for missing hikers. The village has a satellite telephone and satellite Internet access, available to all staff 
members who stay for more than three weeks. The satellite phone is generally reserved for emergencies and business purposes, but the managers occasionally allow other staff members to use it for interviews and other important calls. Holden Village accepts guest reservations via Internet, and also includes staff application packets on its website. Since 2006, a large new chalet for guests has occupied the space that once belonged to the original Chalet 2, which burned down in 1969.

In recent years, an important development has been the initiation of a large-scale mine remediation project, supervised by the international mining company Rio Tinto, whose subsidiary, Intalco, inherited responsibility for the byproducts of the Howe Sound operation through a series of company purchases, and is paying for the project. The project's aims include stabilizing the lower tailings piles by building a underground barrier where their bases meet the creek (partly to prevent the tailings from spilling into the creek in the event of an earthquake or other natural disaster, and partly to prevent the polluted groundwater under the tailings from leaching into the creek), diverting a section of the creek to a course further north (nearer to the village) of that to which Howe Sound originally diverted it to make room for the piles, the installation of a water-treatment plant on the creek, and possibly, the scrapping or burial of what remains of the mill structure. The pollution that the project seeks to remedy is not thought to be a threat to the village residents, as the toxic stream coming out of the mine portal does not empty into the domestic water supply, which comes from Copper Creek, a tributary of Railroad Creek whose ultimate source lies in the snowfields on the east flank of Copper Peak. However, for the several hundred yards where Railroad Creek flows past the tailings, 
there is a dead zone, devoid of aquatic plants and invertebrates. The water-treatment plant will be installed downstream of this zone. ${ }^{126}$

Not everyone is entirely pleased with some elements of Holden Village's modernization and expansion, or with the remediation project, which some residents have deemed unnecessary because (as they see it) the pollution levels involved are relatively insignificant, chiefly affecting one small section of the creek. During the summer of 2011, the directors asked three summer staff members to leave the village for underage drinking. A significant percentage of the residents felt that the directors had not acted fairly, as the three staff members in question had not been caught drinking in the village, but rather at a party in Stehekin. The dissatisfaction generated by this incident also brought out latent feelings that Holden was assuming a more commercial aspect as a result of its catering to the companies involved in the mine remediation project, which had begun in earnest that summer. At a meeting between the directors and a large group of disgruntled young staff members, one of the three who had been asked to leave expressed the opinion that Holden was no longer a community, but rather a business.

In fact, it is both, and has been for a long time. Holden is a community whose sole business is hospitality. True, it remains a non-profit religious organization, and probably always will. But without guests and donors to pay for virtually all its operational expenses, including staff stipends, it would shut down as certainly as the mining community shut down when Howe Sound decided that operating the mine was no longer desirable from a commercial standpoint. All its residents would have to leave. Holden Village, Inc., may not be a company in the true sense, but, insofar that living at

\footnotetext{
${ }^{126}$ Brent Diamond, email correspondence with author, 22 December 2012.
} 
Holden is tied to the success or failure of a single enterprise, and in other important ways discussed in this chapter, it is a company town.

Granted, to label Holden Village a company town is to make creative use of the term. The fact that it is not a commercial enterprise works against this characterization, as all historical company towns (and the modern corporate super-campuses highlighted near the end of Hardy Green's book) have been run by for-profit enterprises, sometimes immensely powerful companies. However, most scholars have not defined company towns by the exact nature of the entities that run them, but, primarily, by the fact that they are towns where there is one employer that usually controls all business and property, including housing. Except in the fact that the federal government owns the land the townsite stands on, and in the fact that some of its workers are not paid employees, Holden Village generally meets these criteria, in some small ways more so than its predecessor community.

The rest of this chapter consists of several sections describing certain parallels between the Holden and Holden Village communities. Those that are most supportive of the argument that Holden Village is a company town are listed first, followed by others that highlight similarities that can be attributed largely to the shared location.

\section{Parallel: Employment \& Residency}

Arguably the most important defining aspect of life in any company town is the close relationship between employment and residency. It is this which makes company towns different from small communities that may be similar in many other regards. In most company towns, if the company dismissed an employee, that employee had no choice but to leave town, because his housing was company-owned, because there was no 
other business in town from which to secure employment, or for both reasons. This was certainly true at Holden during the Howe Sound years. Employees who disturbed the peace, or who committed criminal acts, could generally count on being fired, which was equivalent to banishment from the community. Most of those who left Holden in this fashion landed on Howe Sound's blacklist, which was kept at the company office in Chelan. Those on this list who came seeking reemployment could expect to be told that there was no work to be had at the moment. (It is interesting to note that dismissal did not necessarily mean that a worker's family had to leave the community with him. Gary Bannister's father quit, preempting dismissal, after striking a fellow employee, but the rest of the family was allowed to stay until Bannister finished the eighth grade in 1949). ${ }^{127}$

Alcohol was a common factor in several dismissals. Though Howe Sound banned the sale of alcohol in town, and did not allow it to be served at public functions, Holden was not a dry community. Men drank at and presumably brought alcohol from the tavern in Lucerne, brought it or had it shipped from Chelan, or home-brewed it. In 1949, a miner was jailed for the illegal possession and sale of $\$ 2,500$ worth of liquor. In September 1947, an accusation of theft at one of the card tables sparked a drunken brawl that began in the basement of the recreation hall and continued on Main Street. Chief Engineer Wellington Phillips fired most of the men involved in this incident and sent

\footnotetext{
${ }^{127}$ Gene Starcher, interview with author, Chelan, Washington, 27 March 2012; Bannister, "Memories of School at Holden, 1941-1949," Audio Archive.
} 
them "down the mountain." One man, however, successfully pleaded his innocence to Phillips, who let him become eligible for rehire after one month. ${ }^{128}$

Dismissals and less direct invitations to leave Holden Village are not typically the result of brawls, but they sometimes involve violations of the village policy on the use of alcohol or illegal drugs, and they sometimes have the same effect of forcing a person or persons to leave a place where they have been living for several months, if not longer. It is true that many dismissals have involved volunteer staff members, who are not, strictly speaking, employees. During his year as director, Fritz Norstad addressed the mounting use of marijuana in the village, which was (and is) forbidden by Holden Village policy. He essentially asked those residents who were users to choose between quitting and voluntarily leaving Holden; at least 12 staff members decided to leave, though some later returned. ${ }^{129}$ This being before John and Mary Schramm began negotiating stipends with staff members, most or all of those who left must have been unpaid volunteers. However, over the last 30 years, a number of paid staff members, including a few who had been or were planning to be in the village for at least a year, have been dismissed. Of the three who were dismissed in the summer of 2011, two were paid summer area heads. A few years previously, a long-term staff member was dismissed for supplying alcohol to a minor. The slang term for having to leave the community in this way is being "NBO'd" (Next Boat Out).

\footnotetext{
${ }^{128}$ Sartain interview, Audio Archive; Paasch interview, Audio Archive; Linda Powell Jensen, guided tour; "Man jailed, fined on liquor charge," Wenatchee World, August (?) 1949; Wellington Phillips to J.J. Curzon, 10 September 1947. This incident was one of the primary catalysts for the creation of Niles Sims' position of town constable. In a memo to Curzon, Phillips wrote: "This whole affair has stirred up the camp to a very great extent...I highly recommend obtaining someone from the sheriff's office to keep the peace. Some means might also be had for obtaining notice of large purchases of liquor in Chelan."

${ }_{129}$ Janssen interview; Werner Janssen, email correspondence with author, 30 November 2012.
} 
There were and are obvious differences between being NBO'd from Holden and being NBO'd from Holden Village. The men who were dismissed during the mining years were making a hard living before they were fired, and some had families to support. By contrast, most (but certainly not all) Holden Villagers who are forced to leave are young people without dependents, who do not view their work at Holden (paid or unpaid) the same way as they would a full-time job; rather, their time in the village is a pleasant interlude in lives that often lead them back to school or to other church-related non-profit work. Moreover, with a few exceptions, those who were dismissed during the mining years did not have the option to return one day; theirs was a permanent exile. Holden Village generally permits those it asks to leave to come back after a few months. As of this writing, two of the three who were NBO'd in 2011 have gone back.

Nonetheless, in both eras, one of the immediate effects on the individuals being dismissed and on the rest of the community was and is to highlight the fact that Holden residents live where they live, for however long or short a period, at the discretion of the management. This applied to virtually every member of the mining community, and it applies to every Holden Villager. The managers and directors themselves are obliged to leave if their superiors decide to remove them, as happened to Carroll Hinderlie, and as may have happened to J.J. Curzon toward the end of the mining years.

\section{Parallel: Housing}

The relationship between employment and residency is a function of Holden's isolation, as are most other parallels between the two communities. However, there is one parallel that cannot be completely explained by the remote setting. This is the way in which the community has been segregated. Certain chalets tend to be inhabited by 
managers and their families; similarly, certain chalets were assigned to particular Howe Sound positions during the mining days. At least at present, the chalets toward the top of the hill are mostly inhabited by managers and their families, while those lower down, especially 1 and 3, are inhabited by single people or young couples, most of whom are long-term staff members or summer area heads. The community's more transitory population, which includes short-term volunteers and guests, lives almost entirely in the dormitories, as did those Howe Sound workers who were least likely to become longterm members of the community. While there are sound practical reasons for this arrangement, it contributes to the existence of a loose social hierarchy within the community.

Whether intentionally or not, Howe Sound planned the community in such a way that the management and several other salaried employees were segregated from the rest of the population by virtue of higher-quality housing and physical location within the townsite. The allocation of certain chalets to men who held certain high-ranking staff positions emphasized the importance of those positions. The arrangement of the other "neighborhoods" created rough segregations between well-educated professionals who had not yet become salaried employees (Honeymoon Heights), and other workers from more modest educational backgrounds (Winston Camp, the dorms). Staff housing and employee dormitories were owned by the company.

However, the segregation should not be overemphasized. No significant manmade or natural barriers separated the chalet residents from the dorm residents. The managers did not live much further away from the noise of the mine than the rest of the employees. Some of the better-educated employees, including many of the engineers, did 
not live in the chalets or in Honeymoon Heights, but alongside employees from more modest educational backgrounds, whether in Winston or in the dormitories. The chalets were not vastly larger or more luxurious than some of the privately-built homes in Winston. Compared with other, more famous company towns, the housing division at Holden was fairly unremarkable. Earlier in the twentieth century, in the lumber town of Potlatch, Idaho, Weyerhaeuser built employee housing on two hills, which were separated by the town's business district. Laborers lived in cottages or bunkhouses on the north hill, while the managers lived on the south hill in comfortable homes built around a grassy park. The managers' homes had the indoor plumbing that many of the workers' homes lacked, and they were heated by heaters or water boilers, while the workers' homes were heated by stoves. At the World War II research community of Los Alamos, which resembled a company town, similar conditions prevailed: the top scientists and other project managers lived in a cluster of houses that had indoor plumbing, while other workers were housed in cruder accommodations. ${ }^{130}$

At Holden Village, too, while housing assignments create some division, it only goes so far. Without the sub-communities of the mining years, the town's population is entirely concentrated in the townsite, and is united as one community by meals and daily worship. Most relations between the managers, other long-term staff members, shortterm staff members, and guests are generally quite casual. Moreover, the housing division that does exist is not completely fixed: while guests and short-term volunteers almost always stay in the dorms, the chalets may be put to different use from one year to

\footnotetext{
${ }^{130}$ Petersen, 88, 91-92; Carl Abbott, "Building the Atomic Cities: Richland, Los Alamos, and the American Planning Language," in Bruce Hevly \& John M. Findlay, eds., The Atomic West (Seattle: University of Washington Press, 1998), 94.
} 
the next. A chalet that has been used to house four or five long-term staff members may eventually be assigned to a manager and his or her family, or vice-versa. Also, there are some units, including Agape, the former hospital building, which have been used to house managers and other staff members at the same time.

\section{Parallels \& Differences: The Company Store}

As previously noted, Holden did not fit the stereotypical company-town image in that it lacked the kind of company store that occupied a domineering role in the community, an important feature of other company towns in the West. In extreme cases, shopping at such stores was a condition of employment by the company running the town, the goods sold at them were overpriced, and the workers became so deeply enmeshed in debt to the store that they became virtual slaves of the operation, unable to leave because they could not pay what they owed. More typically, the company store played a central role for the simple reason that the town was too remote for the store to have much competition from other businesses. This situation became less common as the West grew more settled, and was no longer the norm by the time the Holden mine began operation. In larger company towns, such as Phelps Dodge's copper-mining Bisbee, Arizona, the company eventually permitted numerous private businesses to set up shop. ${ }^{131}$ The presence of independent businesses at Holden, such as the grocery store, was not so unusual that it set Holden apart from other company towns of the same era.

In this small and relatively unimportant regard, Holden Village may fit the company-town image more neatly than its predecessor, but only at a superficial level. In 1975, the village opened a bookstore on the basement level of the Hotel building.

\footnotetext{
${ }^{131}$ Allen, 132; Margaret Crawford, Building the Workingman's Paradise (London: Verso, 1995), 130. 
Initially, it carried textbooks for the Lifestyle Enrichment program, Bibles, books for pastors, books authored by guest speakers and summer faculty members, children's books, books on environmental topics, and hiking guides. It expanded to sell clothing marked with the Holden Village logo, a wide range of fiction and non-fiction literature, pottery made in the village, postcards, knitting supplies, snacks, and other small items. It resembles a company store insofar that it is the only store in town, it is part of the Holden Village operation, and it is where many residents buy certain necessities, such as basic toiletries. However, today's long-term residents are not dependent on it, both because they have fairly frequent opportunities to shop during downlake excursions, and because they can order items online. A few still order goods from a grocery store in Chelan. The bookstore might be considered a company store, but it may not significantly enhance or diminish the argument that Holden Village is a company town, because the presence of a company store has not been a key element in the historical definition of what constitutes a company town. ${ }^{132}$

\section{Parallels \& Differences: Public Utilities}

Like most company towns, both Holden communities were self-reliant with regard to public utilities, with the notable exception of power in the case of the mining community. In the mining years, the company also provided services that included garbage collection, limited law enforcement, limited medical care, and limited fire protection (the latter three are discussed in the next section). While this is not a key

\footnotetext{
${ }^{132}$ Deane, 70; Weber, 42. At some point during the 1970s, the village also set up the Hike Haus for the purpose of lending hiking and fishing gear to guests and residents. It shared space with the bookstore before moving to its current location at the west end of Dorm 6. The post office and guest registration were also located in the Hotel basement; while the post office remained there, registration later moved upstairs to one of the two offices outside the northeast corner of the dining hall.
} 
parallel in support of the argument that Holden Village is a company town, it does serve to illustrate the relative independence of both communities, and how far that independence extended.

Unlike the mining community, the village has become somewhat less self-reliant over time with regard to waste management. Like the miners, the villagers originally dumped their waste in a pit in the tailings. For a time, they also used the large Howe Sound incinerator, which had been left intact at the end of the mining days. At some point during the 1980s, however, Holden Village presumably lost its Forest Service permit to use the tailings as a landfill, and began sending its garbage and recyclable items out to Chelan, as it does today. In response to bear problems associated with the food waste in the tailings dump, the villagers also began a composting program. These two developments presumably led to the creation of the current "garbologist" position; previously, waste management had been among the responsibilities of the labor crew (the "mavericks"). While the existing waste management program is probably more friendly to the environment than the practices that preceded it, it has caused Holden Village to become dependent on a private barge company for transporting its garbage and recyclables downlake, and on the county transfer station in Chelan. Between transportation and disposal fees, each shipment of waste (of which there are 5-6 throughout the year) that goes to the transfer station costs the village more than a thousand dollars. $^{133}$

\footnotetext{
${ }^{133}$ Hinderlie interview; Janssen interview; Bjerke, Audio Archive. On one occasion, one of the cooks accidentally burned a large quantity of flour, causing an explosion that knocked him flat and blew the top off the incinerator.
} 
Although Holden Village is self-reliant with regard to electrical power, as its predecessor community was not, the generation of that power has involved ongoing challenges. In 1960-61, when the LBI feasibility committee was taking a long look at Holden and the problems it presented, Gil Berg recognized that by far the greatest hurdle to bringing the townsite back to life was finding a financially feasible way of powering the buildings. Howe Sound had removed the local substation and transformers in 1957. (The transmission lines from Manson were later removed by salvagers). In Berg's assessment, there were three options: repair the lines and replace the substation, which would cost $\$ 18,000$ and $\$ 1,000$ per year in maintenance fees; generate hydroelectric power on site; or install diesel power generators capable of supporting the town load requirement of 260 kilowatts. ${ }^{134}$ Initially, the village went with the third option. In 1961, the board purchased two reconditioned 50 kilowatt diesel generators from a fishing village in Alaska for $\$ 15,000$, which Wilton Bergstrand and the Forerunners installed at a point on the road roughly halfway between the townsite and Winston. However, they proved an inadequate solution; while burning as much as 10,000 gallons a year, they still fell short of generating enough power to effectively heat the village. To save money on fuel, they were shut down every evening at 10pm, and not fired up again until 5am the following morning. ${ }^{135}$

The wilderness held another potential source of power. In 1963, the village began working on what was envisioned as a permanent solution: a hydroelectric dam harnessing the waters of Copper Creek. The board purchased two 1900s-vintage turbines from an

\footnotetext{
${ }^{134}$ Gil Berg, "Initial Report of Survey Group by Gil Berg," Portal Museum document; "Electric Power Biggest Block in Holden Transfer," Wenatchee World, 13 July 1960;

${ }_{135}$ Wilton E. Bergstand, "Holden Village," Portal Museum document; Berg and Phil interview, Audio Archive
} 
irrigation company in Lewiston, Idaho, which were installed in a facility roughly halfway between Railroad Creek and the remains of the mill structure. Werner Janssen, volunteer Mark Bjerke, and a retired hydro engineer from Wenatchee were among those who took part in this project, which was completed in 1965 with the installation of a new diversion dam at a point over 600 feet uphill from the turbines facility. This final phase could not have been completed without the aid of a 1943 Navy bomb service truck for moving the individual sections of pipe up the steep hillside. Once completed, the dam became Holden's primary source of power, while the diesel generators were relegated to backup units. ${ }^{136}$ Although the dam has remained operational since that time, it requires periodic repairs, and the power it provides is not always reliable or abundant. This is especially true during the winter, when reduced flow in the creek severely reduces the amount of power available to the community and sometimes causes outages. In most winters, the villagers sacrifice the use of certain appliances in most buildings to compensate for this, such as dryers, and, during especially cold spells, refrigerators. During the winter of 2011-12, an avalanche cut off the stream above the diversion dam, depriving the village of power for the better part of a day. However, at least as far as they affect daily life, outages such as these are nuisances (especially to the small utilities crew and the cooks), rather than serious threats to the continuing operation of the village. With regard to electricity, the mining community enjoyed a more reliable source, but, as J.J. Curzon

\footnotetext{
${ }^{136}$ Wrick Dunning, "History of Holden Hydro," 2005, Audio Archive; Bjerke, Audio Archive; Hinderlie interview; Gil Berg to "All Holden Village Volunteer Workers," December 2, 1963; "Lutherans Developing Retreat in Cascades: Given Ghost Town in Alpine Setting," Tacoma Sunday Ledger-News Tribune, August 6, 1961; Werner Janssen, "Holden - Part 1: Past, Present, \& Future," 1984, Audio Archive; Werner Janssen, "Interview of Werner Janssen by Chuck Lutz," 1987, Audio Archive; Rieke, Audio Archive. The bomb truck is functional today thanks to mechanic Terry Sanderson and his predecessors.
} 
made clear in his correspondence, it also had greater need of uninterrupted power because the mine simply could not operate without it.

\section{Parallels \& Differences: Environmental Challenges \& Emergencies}

An obvious parallel between the two communities, and one which can be almost entirely explained by the remote location, is the way in which they have responded to environment challenges, medical situations, criminal behavior, and, above all, fire. In this regard, those differences that do exist are mostly due to the differing resources that were and have been available to the respective communities. Perhaps the most visible difference is Holden Village's lesser ability to respond to avalanches, a hazard of living in the valley that has not diminished since the beginning of the mining years. At least during the early years, the retreat center had very limited resources for clearing snow. In 1966, Holden's vulnerability was emphasized by a huge avalanche that hit the fringe of the townsite, destroying a couple of parked vehicles and damaging a few structures. Tom Ahlstrom remembers another slide that buried a section of the road for about a week at some point during the 1970s, cutting off all traffic to and from the village. Without heavy equipment, all the villagers could do was dig their way out. ${ }^{137}$ Today, Holden Village has a plow and a grader among its resources, but there are times when the snowfall is such that these machines alone are not sufficient to keep the road open for buses or other large vehicles to be used between Holden and Lucerne. During the mining years, while snow slides did sometimes isolate the community, keeping the road open

\footnotetext{
${ }^{137}$ Bjerke, Audio Archive; Ahlstrom interview.
} 
was of critical importance to the operation because it was the only way to get the concentrate out, and a transportation crew of 10-12 men was responsible for doing so. ${ }^{138}$ While Howe Sound's ability to keep the road open was probably superior to that of Holden Village today, the existing community's ability to speedily evacuate seriously sick or injured individuals is on par with or better than that of the mining community during its later years, when helicopters came into service in the area. Over time, Holden Village's ability to communicate with the outside world, and therefore to call in a helicopter evacuation when necessary, has improved. In the early 1960s, the village lacked even the indirect telephone connection with Chelan that the miners had used. However, the village established radio contact with the Chelan County Sheriff's office through Stehekin in 1966, and Werner Janssen also began operating a ham radio set during the mid-1970s. In medical situations not serious enough to warrant a helicopter evacuation, Janssen occasionally used his personal boat to transport sick or injured individuals from Lucerne to Chelan. Today, as noted, Holden Village has a satellite phone to call in emergency situations. While the retreat center does not employ a fulltime doctor, there is at least one nurse or EMT on staff nearly all the time, who is supported by the first response team, most of whose members are trained on site. Fortunately, these individuals rarely have to respond to serious medical situations. Village women who become pregnant typically leave Holden ahead of their due date and give birth in Chelan or Wenatchee, as did most of their predecessors during the mining years. Prior to the mid-1980s, there were no fatalities at Holden Village, though it is possible that there may been fatal climbing accidents in the surrounding mountains. The

\footnotetext{
${ }^{138}$ Phillips, "Holden 1940 Census."
} 
writer is aware of at least one death that has taken place since then, which may have been a suicide. $^{139}$

Holden Village's experiences with fire have largely mirrored those of its predecessor. As in the mining community, there is a strong culture of vigilance against fire, based partly on the memory of past building fires, and partly on the awareness of the danger that forest fire poses to the village. Chalet 2 burned down in January 1969; the fire could not be put out in time because the nearest hydrant failed to produce any water for the hoses. It was only after Terry Sateren opened a bypass valve to divert water from the hydro dam into the domestic supply system that the small contingent of volunteers in the village at that time was able to hose down the neighboring chalets, preventing the fire from spreading. In 1977, a second major fire destroyed the maintenance garage on the south side of the creek, another building dating back to the mining era; this fire was started by a welding torch. There have been a number of forest fires in the general area over the last 50 years. Holden Villagers have aided the Forest Service in its firefighting efforts on at least a few occasions, most recently in 2007, when a major forest fire near Domke Lake forced the evacuation of the village. A skeleton crew of long-term staff members remained behind to protect the buildings from cinders and to support the professional firefighters who worked to contain the blaze. The fire came within several miles of the village before its advance was halted on the southern side of the access road, not far from the top of the switchbacks above Lucerne. ${ }^{140}$ Since the early 1960 s, there has been a fire chief on staff, the first of whom was Forerunner John Hill. The fire chief

\footnotetext{
${ }^{139}$ Janssen interview; Lundholm, Audio Archive; Prieb, Audio Archive; Deane, 45.

${ }^{140}$ Janssen interview; Starcher interview; Bob Hewitt, interview with author, 23 April 2011; Sateren, Audio Archive. The only object in Chalet 2 to survive the fire was Mary Christman's Bible.
} 
works with a professional firefighter who visits the village periodically to train new brigade members and update the fire detection and suppression systems in the buildings. When the alarm goes off, regardless of the time of day, all able-bodied staff members respond. While the brigade members don their gear, the fire chief or his/her lieutenants direct other staff members to search the building indicated by the alarm system for flame, smoke, and occupants, and other staff members stand by the nearest two hose-houses, ready to deploy the hose in the event of an actual fire. (This is quite similar to the fire response in Potlatch during its years as a company town, "where virtually every man in town became a volunteer fireman. Some, the first-line regulars, were more active than others and had periodic, specialized training. But officials directed everyone to drop everything if the fire siren...sounded.") ${ }^{141}$ While the response tends to be rapid and relatively well-organized, the brigade's training emphasizes containing building fires and rescuing their occupants, rather than taking possibly risky measures to save the building. Mainly because criminal acts invariably led to dismissals, crime never prospered at Holden during the mining years, and it lacked any kind of formal law enforcement until Niles Sims was sworn in as town constable. Sims' duties in this capacity were light. Holden Village has never had anyone on staff with an equivalent title or set of responsibilities. If a felony were committed in the village, the management would presumably respond to it by calling in sheriff's deputies, or by escorting the guilty person or persons to Field's Point Landing or Chelan, where officers would be waiting to arrest them. On one occasion, Werner Janssen contacted the Chelan County sheriff's office in response to someone outside the village telling him that the community had a serious

\footnotetext{
${ }^{141}$ Petersen, 125.
} 
drug problem. The sheriff's office actually went to the length of sending up a couple who posed as staff members in an effort to determine how much drug use was taking place. The couple reported that a few staff members were marijuana users, but not as many as Janssen had been led to suspect. ${ }^{142}$ This episode forms a rough parallel to the time when J.J. Curzon contacted the FBI to request help in identifying the author of a letter that he deemed subversive to the operation. In both cases, the management turned to professionals to aid in investigating behavior that it saw as a potential threat to the community's peace and stability.

VI. Parallels \& Differences: the Holden School, Recreation, \& Religion

The role that the small school occupies in the life of the community illustrates another parallel between Holden and Holden Village, and a few differences. Today, of course, annual enrollment at the Holden school is much less than it was during the mining years, when there were sometimes hundreds of students. The student body typically includes five to six elementary-schoolers and an equal number of high-schoolers, one or two of whom are boarding students sponsored by a long-term staff couple or family. Often, there is only one graduating senior. Unlike its predecessor, the Holden Village school is part of the Chelan district. It is termed a "remote and necessary" school due to the fact that it is located in a "nontransient" community more than an hour away from the nearest regular school; as such, the state supports it financially. Other Washington communities that feature remote and necessary schools include several small islands in the San Juans. Holden is the only one that offers high school courses. One of the two teachers takes charge of the elementary-schoolers, while the other teaches the high-

${ }^{142}$ Janssen interview. 
schoolers. As was the case during the mining years, other members of the community contribute as official or unofficial teacher's aides, which allows for fairly specialized instruction. In 1975, when there 22 students, a newspaper article characterized 33 residents as aides, including two individuals with doctorate degrees and three with master's degrees. ${ }^{143}$ Graduation from the eighth grade was a festive occasion during the mining years. At Holden Village, graduation from the $12^{\text {th }}$ grade has similar importance as a social event. The typical presence of one senior has led to a number of tongue-incheek graduation ceremonies, at which the graduate has done such things as make two separate speeches - one as valedictorian, and one as salutatorian. The first day of school has also become something of a Holden Village holiday. It is a day characterized by jokes and antics, which include the village children riding a bus from Chalet Hill to the area outside the mine portal (the "third level") and then back to the school.

The school was one cornerstone of social life in the mining community. The array of recreational activities supported and encouraged by Howe Sound formed another. The rec hall became the community's main gathering space, as did similar buildings in other company towns, such as Roslyn, Washington, where the Northern Pacific Coal Company built an athletic facility for its workers that included a gym, a dance hall, meeting rooms, and a bowling alley; and Potlatch, where the gym became a center for dances, plays, and other social events. ${ }^{144}$ Organized sports such as softball, basketball, and bowling were all highly popular activities that the whole community took part in. At Holden Village, many guests and residents play basketball, table tennis, floor

\footnotetext{
143 Terry Bergeson, "Remote \& Necessary Schools Report," 30 December 2008, accessed 26 December 2012, http://www.k12.wa.us.gov; Wenatchee World, "Holden has 18" of snow now," 28 October 1975; "School visit is overnight trip," 19 March 1975; Martha Sirguy, "Holden School: Glimpses Past \& Present," 1998, Audio Archive; Hinderlie interview.

${ }^{144}$ Jaymi Trimble, Images of America: Roslyn (Chicago: Arcadia Publishing, 2008), 11; Petersen, 131
} 
hockey, and pool. They hike, fish, and ski, as the miners did. July 4 and Labor Day are both major holidays in the village - the first involves a parade of vehicles and makeshift floats representing the different work areas, the singing of patriotic songs, speeches, games, and generous meals of all-American food; Labor Day usually involves a large outdoor meal and a softball game, either next to the school building or on the overgrown field. Both holidays held similar importance in the mining community; the company sponsored the July 4 festivities, while the union sponsored Labor Day. July 4 typically involved a variety of games, including foot races, relays, a tug of war, and a baseball game, as well as more bizarre competitions, such as chicken chasing and cracker eating contests. ${ }^{145}$ It is probably fair to say that worship gatherings play a more central role in uniting the village community on a daily basis, as worship lies at the heart of Holden Village's mission and purpose. However, as during the mining years, the rec hall (now called the Village Center), is the site of most of these gatherings, if only for the simple reason that it is the largest indoor space in the village.

\section{Parallels \& Differences: Community Government}

Neither community was or has been a democracy, nor a dictatorship. In the mining community, while the management or the company president had the final say in most matters, the workers and their families were not without a voice. The Community Club, which organized most recreational activities, was not run by the company, but by officers elected by the workers. The workers were unionized, and the union representatives did not only speak for the working community during strikes, but also in

\footnotetext{
145 " $4^{\text {th }}$ of July Celebration -1944 . Morning \& Afternoon Program - July $4^{\text {th }}$. 'At the Ball Park'," Howe Sound Company files, Special Collections, Allen Library, University of Washington.
} 
such matters as the official complaint about the conduct of the company doctor, Theo Gallup. Granted, J.J. Curzon chose not to respond to that complaint by removing Gallup, as the workers would have preferred. However, it is likely that the complaint spurred his subsequent efforts to replace Gallup with a less abrasive doctor. When Gallup resigned (apparently of his own free will), Curzon found a successor, Dr. Jack Carleton, who proved much more amenable to the community.

At Holden Village, while there is, of course, no union, and the management makes many important decisions without consulting the community as a whole, staff members have the opportunity to add their voices to certain decisions affecting their daily lives, mostly through the forum of weekly or bi-weekly (depending on the time of year) meetings of the entire staff. At one such meeting in the fall of 2011, the main topic of discussion was a housing problem: a family of four was joining the long-term staff, and there was limited space in the chalets at that time. The two options being discussed were opening one chalet that was not typically used during the off-season because it was not fully winterized (which would have put additional strain on the already limited power supply) and asking two long-term staff members to move out of the first floor of the chalet they were living in to make room for the family. One of these two expressed the opinion that it was better for him and his neighbor to move than to increase the village power needs, and, ultimately, this is what happened.

\section{Parallel: Racial Diversity}

As a final parallel, it is worth noting that Holden has never been a place of strong racial diversity. A 1948 Holden Miner article noted the presence of a black girl at a children's basketball game, but did not say whose child she was. There were at least a 
few Mexican workers present during the later years of the operation, but no non-whites listed in the 1940 census. None of the managers belonged to racial minorities. This was often the case even in company towns that were racially or ethnically diverse, such as Potlatch, which had a sizeable population of Japanese, Greek, and Italian workers, but they always occupied the lowest rung of the social and economic ladder in the community; the managers were always Americans of Northern European extraction. ${ }^{146}$ Holden Village's guest and staff populations have always been largely white, but not because non-whites have been deliberately excluded from the community. On the contrary, at many times in the past, the village staff has included individuals from nonLutheran, non-white backgrounds. A 1967 Chelan Valley Mirror article noted that the kitchen staff included volunteers from Korea and New Guinea, as well as Osage and Cherokee Indians from Oklahoma. The first black faculty member arrived at some point in the late 1960s; after a Chelan motel refused him lodging, Carroll Hinderlie went downlake to have a "come to Jesus" conversation with the motel owners. ${ }^{147}$ For a period during the 1990s, the village pastor was a black man. Today, the summer program regularly includes a week, called Abriendo Caminos (“Opening Ways”), during which Hispanic residents of the Wenatchee area form the entire guest population, and the worship services are in both English and Spanish. For each of the last few summers, the short-term staff has included a small number of Japanese students. However, the membership of the Lutheran church remains predominantly white, and most guests and staff members discover Holden Village through the church. (The website promotes the

\footnotetext{
${ }^{146}$ The Holden Miner, 15 March 1948; Petersen, 121

${ }^{147}$ Deane, 46; "Holden Village has international staff for summer season," Chelan Valley Mirror, 29 June 1967
} 
village as "an ecumenical retreat center rooted in the Lutheran tradition.") Partly for this reason, the long-term community typically features little racial diversity.

\section{One Key Difference: Length of Residence}

One difference between the two communities that should not be ignored in any comparison is the fact that most long-term residents of the Village community would probably not have been considered long-term in the mining community. The mining community was much more of a town in the sense that it had a stable population; some of its residents stayed for more than decade. Few have done so or been able to do so during the Village era. This could be a limiting factor in the argument that Holden Village is a company town. However, by contrast to the residents of Honeymoon Heights and Winston, many of the employees who lived in the dorms were transient residents. Likewise, the population of Holden Village is constantly changing, but it features a core group of managers and other long-term staffers who stay for two to five years at a time. 


\section{CONCLUSION: HOLDEN'S SIGNIFICANCE, IDENTITY, \& FUTURE}

In composing this thesis, I have been both aided and challenged by my own experiences at Holden Village, where I lived from March 2011 to June 2012 after several stints on short-term staff between 2007 and 2010. I gained a deeper appreciation for the impact life in the village has on its residents, but it became difficult to see past the significance Holden had for me personally to whatever importance it may have at other levels. I suspect that other current and former residents who read this will understand what I mean. What, then, is Holden's significance at a scholarly level? Some may feel that my attempt at defining Holden Village as a company town is a distortion of its true nature, or that it overlooks the fact that many residents who have lived there longer than I have trouble describing it in any categorical way. What, then, is at the heart of Holden's identity, and what does its future hold?

In answer to the first question: as far as the mining community is concerned, Holden's historical significance may not be any less or more than that of other company towns of the same era. It may have been unique in some ways, but there were other company towns in the Northwest that had many features in common, including the isolated setting that has left such a strong impression on generations of residents and guests. This was especially true of Seattle City Light's Newhalem and Diablo in the Skagit River valley, which still exist as company towns today. Newhalem was founded in 1921. A list of the buildings that composed the original townsite makes it sound quite similar to Holden: 75 three-bedroom cottages, six bunkhouses, a cookhouse, and a warehouse. In its first year, it had 1,000 residents. A company railway provided Newhalem's residents with access to the outside world prior to the building of the North 
Cascades Highway in the 1950s, but that connection could be tenuous: in January 1925, an avalanche blocked the tracks and isolated the community for three weeks. This happened again a number of times before the highway was built. Newhalem shared Holden's vulnerability to fire, as well. In 1924, the Forest Service deputized the town's entire adult male population to fight a nearby forest fire. ${ }^{148}$ While such an extreme situation never occurred at Holden, Howe Sound did loan miners to the Forest Service to fight blazes in the area on at least a couple of occasions.

One thing that made Holden unusual was its legacy. Many other company towns were built in spectacular locations, and some were turned to recreational uses after they ceased to be company towns. For example, Ryderwood, Washington, became something of a resort community for senior citizens. ${ }^{149}$ Most, though, including those that have followed this course, have since become incorporated or independent communities. Holden never achieved this status. Its significance lies in the fact that it was a company town that was succeeded by another company town, or, at least, a community with many characteristics of a company town that occupies the same buildings and general environment as its predecessor, and which has not expanded in area or population. It is a case study that illustrates how many features of life in a Western company town are primarily the cause of setting. These features include most of the parallels listed in the last chapter, especially the link between employment and residency and the community's relative self-reliance with regard to public utilities and services.

In answer to the second question: Holden Village's identity is far from fixed or definite, and would not be characterized in exactly the same terms by any two residents.

${ }_{148}$ Pitzer, 32-38

${ }^{149}$ Carlson, 144 
To simply call it a retreat center, or a company town, would be insufficient to those who have spent long periods there. Volunteer Hortie Christman was famous for saying: "If we understood this place, we'd have spoiled it." Reflecting on his time as director, John Schramm simply said: "Holden is what Holden is today." Paul Hinderlie describes Holden as a "risky place," an "unintentional" community that cannot be conformed to any one person's vision of how it should be. ${ }^{150}$ Because anyone can make a guest reservation through the website, and the guests form a major part of the community, and also because through-hikers and Forest Service workers frequently have interactions with the residents, Holden Village defies characterization as a "closed" community, a place to which admittance is strictly controlled and granted on a case-by-case basis.

To many of its residents, Holden is, quite simply, home. This fact is clearly illustrated by the way residents of both eras have felt about the place after leaving. The deep homesickness experienced by Pat Schonders when her family left Holden in 1957 is often mirrored by the feelings of departing long-term staff members, as well as some shorter-term residents. The village tends to draw certain staff members back again and again; it has an addictive quality. Volunteer Bob Hewitt recalls seeing Terry Sateren leave the village after multiple years on staff, having been told by Carroll Hinderlie that he had become too dependent on Holden, an assessment Sateren apparently agreed with. ${ }^{151}$ It is likely that some residents would stay indefinitely if they could.

One might argue that it is less the setting than the residents who shape Holden's identity. However, the power of the setting, including those parts of it that are manmade, should not be underestimated. This includes the visible byproducts of the Howe

\footnotetext{
${ }^{150}$ Hinderlie interview; Schramm, Audio Archive.

${ }^{151}$ Hewitt interview.
} 
Sound operation. The tailings, which the Forest Service capped with a layer of gravel in the 1980s, have been the site of birthday bonfires, campouts, graduation ceremonies, and a frisbee golf course. Despite being a blot on the natural landscape, they have become an accepted part of the environment around the village. This is somewhat similar to the situation in Toluca, Illinois, a former coal-mining town, where two enormous piles of mining waste, nicknamed the Jumbos, became so much a part of the town's identity that the residents formed an organization to protect them from reclamation efforts. ${ }^{152}$ Holden Village residents sometimes play basketball on a court built on the foundation of one of the shops or offices that once stood outside the mine portal. Then, of course, there are the townsite buildings themselves, in which the residents have lived and gathered for generations. The different chalets have assumed different characters and reputations, which have both been influenced by and have influenced whom their residents tend to be. In recent years, Chalets 1 and 3, which have the greatest number of young adult residents, have tended to be "party" chalets; attracting some would-be residents and discouraging others.

Holden Village may assume the aspect of a young adult commune in the eyes of some first-time staff members; there is a full, almost utopian quality to life there that is especially appealing to young singles. (One older staff member supposedly remarked that he came to the village expecting to find a Benedictine monastery, but instead found a college fraternity.) Holden has this in common with other small, communal societies. Laura Fermi commented on how life among the community of young scientists and their

\footnotetext{
${ }^{152}$ Hemalata C. Dandekar, "Review Essay: Planned One-Company Towns and Unplanned Allegiances: Arnold R. Alanen, Morgan Park: Duluth, U.S. Steel, and the Forging of a Company Town. Minneapolis: University of Minnesota Press, 2007. David Robertson, Hard as the Rock Itself: Place and Identity in the American Mining Town. Boulder: The University Press of Colorado, 2006," Journal of Planning History 9, no. 66 (2010): 66-70, 68 .
} 
wives at Los Alamos was so intense that the year and a half she spent there seemed like a significant portion of her life, even many years later. ${ }^{153}$ However, it is misleading to think of or characterize Holden Village as a utopia. It is not a place apart from the world's problems, but merely a place where their effects are felt less sharply. And it has problems of its own, including the environmental challenges described in earlier chapters. Moreover, utopian perceptions of Holden may lead to forgetfulness of the fact that living there can be tenuous, and is made possible mainly by the guests and donations. Holden Village was reminded of the fragility of its existence and its dependence on charity after the 2007 evacuation, which caused a loss of revenue that had to be compensated for with a large-scale fundraising drive.

Naturally, the future of the village is not so easy to determine. The mine remediation project will change the face of the environment around the village in certain ways, and has prompted the management to contemplate a number of projects of its own. The former museum building, the composting bins, and the temporary waste storage units currently in use will probably be removed in the course of the remediation. Consequently, there has been discussion of building a new museum closer to the village and discussion of modernizing the village waste management facilities. As of December 2012, at least one step has been taken: two new composting units have been put into service, which should allow the village to process food waste at a much faster rate. More importantly, perhaps, the remediation is changing the face of the Holden community, at least in the short term. The workers associated with the project are being housed in the dorms and Chalet 2 during the construction season at Rio Tinto's expense. During the

\footnotetext{
${ }^{153}$ Abbott, "Building the Atomic Cities," in The Atomic West, 98.
} 
summer and fall of 2011, while free to participate in Holden Village activities outside of their work hours, the workers were generally fed separate meals, and mostly did not attend worship services, fostering the existence of two separate communities within the village. The writer heard a number of staff members comment on the oddness of this state of affairs. However, there were also a fair number of friendly relations between the villagers and the workers. In the spirit of the village, some of the project managers tiedyed their work shirts. A physician assistant among the contract workers brought her family to Holden for Thanksgiving after the work season was practically over.

However, will the remediation change the nature of Holden Village's connection to the outside by introducing more media technology? Will it continue to influence the rise in the number of paid staff positions? Will it eventually cause the residents to lose sight of Holden's past as a mining town? These questions are much harder to answer. In all probability, the residents will never completely lose sight of the community of people who went before them, but the removal of such relics as the remains of the mill structure may cause the mining history to become less a part of their daily awareness.

The flooded mine itself has occasionally found ways to remind the residents of its existence. In 1977, a buildup of water and debris burst through the sealed portal, leading Bob Hewitt, a Forest Service worker, and a geologist from the University of Washington to explore the upper levels. They discovered a number of relics, including abandoned equipment, clothing, lunch pails, and magazines. Though not the last to enter the mine, they were probably the last to climb the ladders to the chambers and tunnels above the 
level of the portal. ${ }^{154}$ Such excursions into the depths of Holden's past now belong themselves to a former era.

Additional research into Holden's history and background might include study of the following:

1. The Howe Sound Company files archived at the University of British Columbia, in Vancouver, which this writer did not have time to investigate. There is also a collection of Howe Sound files housed in the Royal BC Museum in Victoria, British Columbia.

2. The mining operation itself, whose technical aspects are documented to some extent in the company files archived at the University of Washington.

${ }^{154}$ Paul Hinderlie and Larry Howard, guided tour; Hewitt interview 


\section{BIBLIOGRAPHY}

\section{Monographs \& Anthologies:}

Adams, Nigel B. The Holden Mine: Discovery to Production, 1896-1938. Wenatchee: World Publishing Company, 1981. (This is the published book version of Adams' dissertation)

Allen, James B. The Company Town in the American West. Norman: University of Oklahoma Press, 1966.

Bachmann, E. Theodore. The United Lutheran Church in America, 1918-1962. Minneapolis: Fortress Press, 1997.

Carlson, Linda. Company Towns of the Pacific Northwest. Seattle: University of Washington Press, 2003.

Crawford, Margaret. Building the Workingman's Paradise: The Design of American Company Towns. London: Verso, 1995.

Dinius, Oliver J., and Vergara, Angela, eds. Company Towns in the Americas. Atlanta: University of Georgia Press, 2011.

Erling, Maria, \& Granquist, Mark. The Augustana Story: Shaping Lutheran Identity in North America. Minneapolis: Augsburg Fortress, 2008.

Etulain, Richard W., and Malone, Michael P. The American West: A Modern History, 1900 to the Present. Lincoln: University of Nebraska Press, 1989.

Findlay, John M., and Hevly, Bruce, eds. The Atomic West. Seattle: University of Washington Press, 1998.

Garner, John S., ed. The Company Town: Architecture and Society in the Early Industrial Age. Oxford: Oxford University Press, 1992.

Gilbert, W. Kent. Commitment to Unity: A History of the Lutheran Church in America. Philadelphia: Fortress Press, 1988.

Green, Hardy. The Company Town: The Industrial Edens and Satanic Mills that shaped the American Economy. New York: Basic Books, 2010.

Hitchman, Robert. Place Names of Washington. Washington State Historical Society, 1985.

Hoagland, Alison K. Mine Towns: Buildings for Workers in Michigan's Copper Country. Minneapolis: University of Minnesota Press, 2010. 
Lutz, Charles P. Surprising Gift: The Story of Holden Village, Church Renewal Center. Chelan: Holden Village Press, 1987.

Mikesell, Raymond F. The World Copper Industry: Structure and Economic Analysis. Baltimore: The Johns Hopkins University Press, 1979.

Milner, Clyde A., O'Connor, Carol A., and Sandweiss, Martha A., eds. The Oxford History of the American West. New York: Oxford University Press, 1994.

Murphy, Mary. Mining Cultures: Men, Women, and Leisure in Butte, 1914-41.

Chicago: University of Illinois Press, 1997.

Navin, Thomas R. Copper Mining \& Management. Tucson: The University of Arizona Press, 1978.

Nelson, E Clifford. Lutheranism in North America, 1914-1970. Minneapolis: Augsburg Publishing House, 1972.

Petersen, Keith C. Company Town: Potlatch, Idaho, and the Potlatch Lumber Company. Pullman, WA: Washington State University Press \& Latah County Historical Society, Moscow, Idaho, 1987.

Pitzer, Paul C. Building the Skagit. Seattle: The Galley Press, 1978.

Shifflet, Crandall A. Coal Towns: Life, Work, and Culture in Company Towns of Southern Appalachia, 1880-1960. Knoxville: The University of Tennessee Press, 1991.

Trimble, Jaymi. Images of America: Roslyn. Chicago: Arcadia Publishing, 2008.

\section{Articles:}

Crawford, Margaret. “The 'New' Company Town.” Perspecta 30 (1999): 48-57.

Dandekar, Hemalata C. "Review Essay: Planned One-Company Towns and Unplanned Allegiances: Arnold R. Alanen, Morgan Park: Duluth, U.S. Steel, and the Forging of a Company Town. Minneapolis: University of Minnesota Press, 2007. David Robertson, Hard as the Rock Itself: Place and Identity in the American Mining Town. Boulder: The University Press of Colorado, 2006.” Journal of Planning History 9, no. 66 (2010): 66-70.

\section{Thesis:}

Plimpton, Christine. An Ethnoarchaeological Study of Honeymoon Heights. Washington State University, unpublished M.A. thesis, 1984. 


\section{Newspapers \& Newsletters:}

The Chelan Valley Mirror, 1937-1980

The Holden Miner, 1948-1957, 1988-2012 (as newsletter)

The Tacoma News-Tribune, 1972

The Wenatchee Daily World, 1937-1980

\section{Archive Collections:}

Holden Village Portal Museum

Howe Sound Company files, Special Collections, Allen Library, University of Washington, Seattle

\section{Oral History Collections:}

Holden Village Audio Archive

\section{Interviews \& Guided Tours:}

Ahlstrom, Tom. Telephone Interview. 29 August 2012

Hewitt, Bob. Personal Interview. Holden Village, 23 April 2011

Hinderlie, Paul, \& Howard, Larry. Guided Tour. Holden Village, 12 August 2010

Hinderlie, Paul. Personal Interview. Holden Village, 26 August 2010

Janssen, Werner. Telephone Interview. 24 July 2012

Jensen, Linda Powell. Guided Tour. Holden Village, 28 June 2010

Jensen, Linda Powell. Personal Interview. Holden Village, 5 July 2010

Jensen, Linda Powell, \& Phillips, Bill. Personal Interview. Seattle, Washington, 25 July 2012

Phillips, Bill. Guided Tour. Holden Village, 11 September 2010 
Schonders, Pat. Personal Interview. Chelan, Washington, 15 May 2011

Starcher, Gene. Personal Interview. Chelan, Washington, 27 March 2012

\section{Other Sources:}

"Background on Gambling in Washington," accessed 23 December 2012, http://www.wsgc.wa.gov/history.asp.

Bergeson, Terry, "Remote \& Necessary Schools Report," 30 December 2008, accessed 26 December 2012, http://www. k12.wa.us.gov.

Deane, Lola, editor. Holden Village: 50 Years of Memories. Chelan: Holden Village Press, 2012.

Weber, Erwin. My Days At Holden: An Illustrated Book of Holden Village, the Lutheran Retreat High in the Cascade Mountains Near Lake Chelan, Washington. Unpublished, 1977. 


\section{APPENDIX A: HOLDEN 1940 CENSUS (AUTHOR'S ANALYSIS)}

I. Highest Level of Education (Adults Only):

Honeymoon Heights:

No high school diploma: 1

High school diploma: 6

Some college: 12

Bachelor's Degree: 12

At least some graduate school: 1

Winston Camp:

No high school diploma: 47

High school diploma: 29

Some college: 11

Bachelor's Degree: 8

At least some graduate school: 1
Staff Housing:

No high school diploma: 9

High school diploma: 10

Some college: 2

Bachelor's Degree: 7

At least some graduate school: 5

Dorms:

No high school diploma: 225

High school diploma: 59

Some college: 29

Bachelor's Degree: 11

At least some graduate school: 5

II. State or Country of Birth (including children):

Honeymoon Heights:

Washington: 20, Utah: 4, Canada: 2, Iowa: 1, Montana: 1, Michigan: 1, Colorado: 1, Kansas: 1, North Dakota: 1, West Virginia: 1, Wisconsin: 1, Illinois: 1, New York: 1

Winston Camp:

Washington: 64, Kansas: 11, North Dakota: 10, Iowa: 9, Montana: 8, Nebraska: 7, Illinois: 7, Oklahoma: 6, Missouri: 6, Minnesota: 5, Indiana: 4, Wisconsin: 4, Arkansas: 4, Canada: 4, Michigan: 3, Oregon: 2, Texas: 2, California: 2, Germany: 2, Ohio: 1, New Hampshire: 1, South Dakota: 1, Alaska: 1, Florida: 1, Utah: 1, Norway: 1, "Mespotania": 1

Staff Housing:

Canada: 15, Washington: 7, Texas: 3, Minnesota: 2, Indiana: 2, Michigan: 2, Oregon: 2, California: 2, England: 2, Russia: 1, Montana: 1, Scotland: 1, West Virginia: 1, Nevada: 1, Illinois: 1, Nebraska: 1, Colorado: 1, North Dakota: 1

Dorms: 
Washington: 87, Unknown: 16, Montana: 15, Nebraska: 14, Minnesota: 13, Iowa: 13, Illinois: 12, Canada: 9, Idaho: 8, Kansas: 8, Ohio: 7, Oregon: 7, North Dakota: 7, Wisconsin: 6, Texas: 6, California: 6, Missouri: 6, Kentucky: 5, Norway: 4, Colorado: 4, Alabama: 4, Michigan: 4, Georgia: 4, Pennsylvania: 3, Italy: 3, New Mexico: 3, Oklahoma: 3, Maine: 3, Sweden: 3, Vermont: 2, Mississippi: 2, Utah: 2, South Dakota: 2, Arkansas: 2, New Jersey: 2, Virginia: 2, Austria: 2, Russia: 2, Germany: 2, Holland: 1, Mexico: 1, France: 1, Persia: 1, Peru: 1, Rhode Island: 1, Tennessee: 1, Massachusetts: 1, Delaware: 1, Arizona: 1, Denmark: 1, North Carolina: 1, Dalmatia: 1, Croatia: 1, Finland: 1, Monoravia (?): 1, China: 1 (this person identified as white)

III. Residence in 1935

Honeymoon Heights:

Chelan County: 7

King County: 12

Elsewhere in WA: 7

Outside WA: 10

International: 1

Winston Camp:

Chelan County: 45

King County: 17

Elsewhere in WA: 17

Outside WA: 52

International: 14

IV. Employed women

Honeymoon Heights: 0

Winston Camp: 7

Staff Housing: 2

V. Average number of children per family

Honeymoon Heights: 1.5

Winston Camp: 1.8

Staff Housing: 1.75
Staff Housing:

Chelan County: 9

King County: 3

Elsewhere in WA: 4

Outside WA: 12

International: 16

Dorms:

Chelan County: 64

King County: 23

Elsewhere in WA: 83

Outside WA: 143

International: 6 


\section{APPENDIX B: HOLDEN 1940 CENSUS (BILL PHILLIPS' ANALYSIS)}

I. Homes

Number of homes:

Honeymoon Heights: 15

Winston: 45

Lucerne: "Gettysburg" 41, "Lee's

Camp" 18

\section{Population}

Overall:

Total: 583

Honeymoon

Heights: 37

Winston: 172

Dorms: 328

Staff Housing: 46

(Lucerne: 171)

III. Jobs Summary

Mine (Underground):

Miner: 78, Powderman/Blaster: 2, Mucker: 69, Hoistman/Cage Tender: 7, Grizzley: 15, Motorman: 5, Driller: 22, Brakeman: 2, Nipper: 19, Timberman: 3

Mill (Surface):

Ore Handler: 1, Flotation Mill: 1, Mill Operator: 11, Ball Mill Operator: 1, Mill Oiler: 1, Mill Worker/Helper: 13

Other:

Blacksmith: 16, Laborer: 15, Mechanic: 8, Warehouseman: 3, Machinist: 5, Carpenter: 9, Electrician: 4, Tram: 2, Truck Driver: 9, Tractor Driver: 1

Dining Hall/Restaurant:

Chef: 1, Vegetable Cutter: 1, Cook: 3, Meat Cutter: 1, Baker: 2, Lunch Maker: 1, Waiter: 9, Dish Washer: 4, Fountain Lunch: 5 
Recreation:

Recreation: 2, Pinsetter: 5, Motion Picture Operator: 1

General Office:

Assayer/Chemist: 4, Metallurgist: 2, Engineer: 15, Geologist: 1, Timekeeper/Steno/Accountant: 15, School Teacher: 2, Barber: 1, Doctor/Nurse: 2, Dental: 2

IV. Age and Employment Status

Average Age:

Honeymoon Heights: 28

Winston: 32.5

Dorms: 33

Staff Housing: 40

Lucerne: 30

Oldest:

Honeymoon Heights: 38

Winston Camp: 59

Dorms: 63

Staff Housing: 54

Lucerne: 54

Unemployed in 1939 (entire community): 54 